\author{
Universidade de São Paulo \\ Instituto de Química de São Carlos
}

\title{
BIOCATALISADORES DE ORIGEM MARINHA (ALGAS, BACTÉRIAS E FUNGOS) PARA REDUÇÃO ESTEREOSSELETIVA DE CETONAS
}

Dissertação apresentada ao Instituto de Química de São Carlos, da Universidade de São Paulo, para a obtenção do título de Mestre em Físico-Química.

\section{Ana Maria Mouad}

Orientador: Professor Doutor André Luiz Meleiro Porto 


\section{Dedicatória}

Dedico este trabalho aos meus pais Luis Antônio e Maria Izildinha, Aos meus irmãos Daniel e Mariana. 


\section{Agradecimentos}

Em primeiro lugar, agradeço a Deus, por estar ao meu lado, me guiando e protegendo em todos os momentos.

Ao Professor Doutor André, pela orientação, amizade, respeito e liberdade de expressão.

Aos amigos de laboratório: Mariana, Lenilson, Julieta, Hércules, Isac, Yara, Gliseida, Scarlet, alunos de IC. Obrigada pelo apoio e companheirismo no trabalho, e pela amizade, bom humor e descontração!

Aos meus pais, que são minha vida e aos meus amados irmãos Daniel e Mariana. Não encontro palavras para expressar minha gratidão e meu amor por vocês!

Professora Dra Hosana M. Debonsi pela grande contribuição neste trabalho, pelo carisma e carinho com que sempre nos recebeu em seu laboratório na FCFRP/USP. Agradeço também aos alunos de seu grupo.

Ao Professor Dr. Roberto Gomes Berlinck e à aluna Stellamar Homminger, pela concessão de linhagens da alga Sargassum sp.

Aos queridos amigos conquistados durante estes anos em São Carlos: Livia (Tarta), Fernanda (Coxinha), Tati, Karen (Kaká), Monise, Scooby, Cóxa, Mp, Bolão, Letícia, Juba, e tantas outras pessoas especiais que transformaram momentos comuns em momentos inesquecíveis de alegria e amizade.

À minhas amigas Renata e Cinthia, companheironas de longa data.

Aos meus amigos Ivan, Beué e Denis, vocês são únicos e exclusivos!

À minha família Giazzi, em especial, à minha "irmã" de coração Camila e à pequena Ana Clara.

Ao Instituto de Química de São Carlos.

Ao CNPq, pela bolsa de estudos concedida. 


\section{RESUMO}

\section{BIOCATALISADORES DE ORIGEM MARINHA (ALGAS, BACTÉRIAS E FUNGOS) PARA REDUÇÃO ESTEREOSSELETIVA DE CETONAS}

Neste trabalho foram realizadas reações de redução de cetonas empregando diferentes organismos marinhos como biocatalisadores (algas, fungos e bactérias). Nas triagens foram utilizados derivados de acetofenonas ( $o$-iodoacetofenona, $m$-iodoacetofenona, $p$-iodoacetofenona, $o$-fluoracetofenona, $o$-cloroacetofenona, $o$-bromoacetofenona, $o$ nitroacetofenona) e duas cetonas 1,3-dicarboniladas: a 4,4,4-triflúor-1-(furan-2il)butano-1,3-diona e a 4,4,4-triflúor-1-(naftalen-2-il)butano-1,3-diona. As reações com as algas marinhas Bostrychia tenella e a Bostrychia radicans levaram aos álcoois com excelentes seletividades (ee >98\%), contudo, obtiveram-se baixas conversões. Foram isoladas as bactérias $\mathrm{Bt}-01$ (B. tenella) e $\mathrm{Bt}-02$ (B. radicans), as quais catalisaram as reduções das acetofenonas com resultados similares aos obtidos com as algas. Os fungos (Br-09, $\mathrm{Br}-23, \mathrm{Br}-27, \mathrm{Br}-61)$ isolados da alga $B$. radicans reduziram as acetofenonas com boas seletividades e conversões. Ainda, reações de redução das acetofenonas com quatro linhagens de fungos isolados da alga Sargassum sp (SMA2C, SMA2-8, SMA2-58, SGPY-41) levaram a obtenção dos respectivos álcoois com diferentes conversões e seletividades. As reduções das cetonas 1,3-dicarboniladas foram realizadas com as algas $B$. tenella e $B$. radicans, e com sete linhagens de fungos marinhos (Aspergillus sydowii Ce15, Aspergillus sydowii Ce19, Aspergillus sydowii Gc12, Bionectria sp Ce5, Penicillium raistrickii Ce16, Penicillium miczynskii Gc5 e Trichoderma sp Gc1). As algas e os fungos marinhos catalisaram a redução regiosseletiva e estereosseletiva das cetonas 1,3-dicarboniladas, onde ocorreu a redução do grupo $\alpha$-trifluorcarbonílico. Concluiu-se que as algas e seus microrganismos associados, e os fungos marinhos têm potencial para serem utilizados como biocatalisadores em reações de redução. Este trabalho foi o primeiro estudo realizado no país envolvendo algas marinhas e seus microrganismos associados em reações de redução de cetonas, cujos resultados são bastante promissores. 


\section{ABSTRACT \\ BIOCATALYSTS FROM MARINE ORIGIN (ALGAE, BACTERIA AND FUNGI) FOR STEREOSELECTIVY REDUCTION OF KETONES}

In this work, were investigated the ketone reduction reactions using several marine organisms as biocatalysts (algae, fungi and bacteria). In the screening were utilized acetophenone derivatives (o-iodoacetophenone, $m$-iodoacetophenone, $p$ iodoacetophenone, $\quad o$-fluoroacetophenone, $\quad o$-chloroacetophenone, $\quad o$ bromoacetophenone, $o$-nitroacetophenone) and two 1,3-dicarbonylated compounds: 4,4,4-trifluoro-1-(furan-2-yl)butane-1,3-dione and 4,4,4-trifluoro-1-(naftalen-2yl)butane-1,3-dione. The reactions with algae Bostrychia tenella and Bostrychia radicans afforded the alcohols with high selectivities (ee > 98\%), however, with low conversions. The bacteria Bt-01 and Bt-02 were isolated from algae B. tenella and $B$. radicans, respectively, which catalyzed the reductions of acetophenones as the same as obtained with the algae. The acetophenones were reduced by several fungi (Br-09, Br$23, \mathrm{Br}-27, \mathrm{Br}-61)$ in good selectivities and conversions. These fungi were isolated from Bostrychia radicans. In addition, the acetophenone reduction reactions were screened with four strains of fungi, which were isolated from algae Sargassum sp (SMA2-C, SMA2-8, SMA2-58, SGPY-41). The alcohols were obtained with different conversions and selectivities. The reductions of 1,3-dicarbonylated compounds were carried out with the algae B. tenella and B. radicans, and marine fungi (Aspergillus sydowii Ce15, Aspergillus sydowii Ce19, Aspergillus sydowii Gc12, Bionectria sp Ce5, Penicillium raistrickii Ce16, Penicillium miczynskii Gc5 and Trichoderma sp Gc1). The algae and marine fungi catalyzed regio- and estereoselectively reductions of the 1,3dicarbonylated compounds. The $\alpha$-trifluoromethylcarbonyl group was reduced preferentially. In conclusion, the algae and associated micro-organisms and marine fungi have potential for catalyzing ketone reduction reactions. This investigation was the first study carried out in the Brazil by using algae and associated micro-organisms in the ketone reduction reactions. The obtained results here are promising and interesting. 


\section{Índice}

\section{Parte I -Introdução}

Introdução 2

Enzimas 3

Classes de Enzimas e suas Aplicações

Vantagens na utilização de enzimas em reações

Cofatores $\quad 9$

Coenzimas e sua participação em reduções de cetonas 10

Regra de Prelog 12

Redução de cetonas para obtenção de alcoóis quirais $\quad 13$

Redução de cetonas com micro-organismos $\quad 14$

Parte II - Materiais e Métodos 20

$\begin{array}{ll}\text { Reagentes e solventes } & 21\end{array}$

Preparação dos álcoois racêmicos $\quad 22$

Algas Bostrychia tenella e Bostrychia radicans 23

Isolamento de bactérias das algas $B$. tenella e $B$. radicans 24

Isolamento de fungos da alga Sargassum sp 24

Isolamento de fungos da alga Bostrychia radicans 26

Fungos marinhos $\quad 27$

Meios de cultivo pra crescimento dos microrganismos 28

$\begin{array}{ll}\text { Água do mar artificial } & 28\end{array}$

Reações de biocatálise com algas B. tenella e B. radicans 29

Reações de biocatálise com as bactérias e fungos isolados das algas (B. tenella, B. 29 radicans e Sargassum $\mathrm{sp)} \mathrm{e} \mathrm{com} \mathrm{os} \mathrm{fungos} \mathrm{marinhos}$

Extração das reações para determinação dos rendimentos 30

Cromatografia em coluna $\quad 31$

Evaporadores rotativos $\quad 31$

Agitador orbital rotativo termostatizado $\quad 31$

$\begin{array}{ll}\text { Outros equipamentos } & 31\end{array}$ 
Isolamento de microrganismos associados às algas Bostrychia tenella

e Bostrychia radicans

Redução de iodoacetofenonas com a alga marinha Bostrychia tenella

Redução de iodoacetofenonas com a alga marinha Bostrychia radicans

Redução de iodoacetofenonas com as bactérias associadas às algas

marinhas Bostrychia tenella e Bosrtychia radicans

Redução de orto-acetofenonas com a alga marinha Bostrychia tenella

Redução de derivados de acetofenonas com os microrganismos isolados

da alga marinha Bostrychia radicans

Redução de derivados de acetofenonas com fungos isolados da alga Sargassum sp

Redução de $\alpha$-trifluormetilcetonas com fungos marinhos

Considerações Finais

Conclusões 



\section{Lista de figuras}

\section{Introdução}

Figura 1. Estrutura primária de uma proteína 3

Figura 2. Exemplos de quimi-regiosseletividade 4

Figura 3.Moléculas de efedrina, ampicilina e cefadroxil obtidas 5

por biotransformações

Figura 4: Coenzimas NADH e NADPH 10

Figura 5. Transferência de íon hidreto do cofator NAD(P)H 12

ao grupo carbonílico no sítio ativo de uma álcool desidrogenase

Figura 6. Redução de cetona para obtenção de álcool quiral 14

Figura 7. Redução de $p$-acetofenonas com Candida magnoliae 15

Figura 8. Redução de derivados de acetofenonas com as algas $C$. merolae 16 e C. caldarium

Figura 9. Redução assimétrica da pentafluoracetofenona com Synechococus sp 16

Figura 10. Biotransformação de $\alpha$-bromocetonas com S. platenis 17

\section{Materiais e métodos}

Figura 1. Cetonas utilizadas nas reações de biorredução 21

Figura 2. Alcoóis racêmicos 23

\section{Resultados e Discussões}

Figura 1. Alga B. tenella e B. radicans suspensas em água esterilizada 37

Figura 2. Bactérias isoladas das algas marinhas B. tenella $(\mathrm{Bt}-01) \mathrm{e}$

B. radicans (Br-01) em meio de cultura NB (nutrient broth)

Figura 3. Colônias de microrganismos obtidas da alga Bostrychia radicans em meio de batata

Figura 4. Fungos isolados da alga Bostrychia radicans e cultivados em meio de cultura de extrato de malte.

*linhagem Br-62 não utilizada nas reações de biocatálise 
Figura 5. Cromatogramas obtidos por $\mathrm{CG}(\mathrm{A})$ padrão

da $o$-iodoacetofenona 1 (B) padrão do 1-(2-iodofenil)etanol rac-4

Figura 6. (A) padrão da $m$-iodoacetofenona 2 (B)

padrão do 1-(3-iodofenil)etanol rac-5

Figura 7. (A) padrão da $p$-iodoacetofenona 3

(B) padrão do 1-(2-iodofenil)etanol rac-6

Figura 8. Reação da $o$-iodoacetofenona 1 com a bactéria $\mathrm{Br}-01$

isolada da alga Bostrychia radicans (8 dias de reação)

Figura 9. (A) padrão da $o$-fluoroacetofenona 7

(B) padrão do 1-(2-fluorfenil)etanol rac-11

Figura 10. (A) padrão da $o$-cloroacetofenona 8

(B) padrão do 1-(2-clorofenil)etanol rac-12

Figura 11. (A) padrão da $o$-bromoacetofenona 9

(B) padrão do 1-(2-bromofenil)etanol rac-13

Figura 12. (A) padrão da $o$-nitroacetofenona 10

(B) padrão do 1-(2-nitrofenil)etanol rac-14

Figura 13. Cromatograma obtido por $\mathrm{CG}$ da reação

da $p$-iodoacetofenona 3 com fungo $\mathrm{Br}-09$ isolado da alga

B. radicans com 10 dias de reação

Figura 14. Cromatogramas das reações de redução com

o fungo Br-09 isolado a alga B. radicans com 10 dias de reação.

(A) $o$-fluorfeniletanol 7 (B) $o$-nitrofeniletanol 10

Figuras 15. Cromatogramas das reações da $o$-cloroacetofenona 8 com fungos solados da alga Sargassum sp com 10 dias de reação

(A) fungo SMA2-8 (B) fungo SGPY-41

Figura 16. Colônias de fungos marinhos cultivadas em extrato de malte $2 \%$

Figura 17. Regra de Prelog para a redução da cetona 17 com fungos marinhos

Figura 18. Cromatogramas obtidos por CG.

(A) padrão da dicetona 15 (B) padrão do álcool rac-17

Figura 19. Cromatogramas das reações da dicetona 15

com fungos marinhos com 7 dias de reação

(A) Penicillium raistrickii Gc5 (B) Aspergillus sydowii Ce19

Figura 20. (A) padrão da dicetona 16 (B) padrão do álcool rac-18 
Figura 21. Cromatogramas obtidos por CG das reações da

dicetona 15 com fungos marinhos em 7 dias de reação

(A) Penicillium raistrickii Gc5

\section{LISTA DE TABELAS}

\section{Introdução}

Tabela 1. Classificação das enzimas

Tabela 2. Vantagens e desvantagens no uso de células totais ou enzimas isoladas

Tabela 3. Redução de cetonas alifáticas e aromáticas com S. cerevisae $\quad 14$

$\begin{array}{lr}\text { Tabela 4. Redução de cetonas com algas marinhas } & 18\end{array}$

\section{Materiais e Métodos}

Tabela 1. Rendimento das reações biorredução

Tabela 2. Dados de rotação óptica e tempo de retenção dos enantiômeros dos álcoois em coluna quiral CP-Chirasil-Dex-CB-Varian

Tabela 3. Programação utilizada no CG para as análises das reações

\section{Resultados e Discussões}

Tabela 1. Redução de iodoacetofenonas $\mathbf{1}$ - $\mathbf{3}$ com a alga marinha Bostrychia tenella

Tabela 2. Redução de iodoacetofenonas $\mathbf{1}$ - $\mathbf{3}$ com a alga marinha Bostrychia radicnas

Tabela 3. Redução de iodoacetofenonas $\mathbf{1}$ - $\mathbf{3}$ com a bactéria Bt-01 isolada da alga marinha Bostrychia tenella

Tabela 4. Redução de iodoacetofenonas $\mathbf{1}$ - $\mathbf{3}$ com a bactéria Br-01 isolada da alga marinha Bostrychia radicans

Tabela 5. Redução de orto-acetofenonas $\mathbf{7}$ - $\mathbf{1 0}$ com a alga marinha Bostrychia tenella

Tabela 6. Redução de $o$-acetofenonas $\mathbf{7}$ - $\mathbf{1 0}$ com a bactéria Br-01 
isolada da alga marinha Bostrychia radicans

Tabela 7. Redução de iodoacetofenonas $\mathbf{1}$ - $\mathbf{3}$ com os fungos Br-09 e

Br-61 isolados da alga marinha Bostrychia radicans

Tabela 8. Redução de $o$-acetofenonas $\mathbf{7}$ - $\mathbf{1 0}$ com os fungos Br-09, Br-23,

$\mathrm{Br}-27$ e $\mathrm{Br}-61$ isolados da alga marinha Bostrychia radicans

Tabela 9. Redução de $o$-acetofenonas $\mathbf{7 - 1 0}$ com fungos isolados da alga marinha Sargassum $\mathrm{sp}$

Tabela 10. Redução da $\alpha$-trifluormetilcetona $\mathbf{1 5}$ com os fungos marinhos 70

Tabela 11. Redução da $\alpha$-trifluormetilcetona $\mathbf{1 6}$ com os fungos marinhos 72

Tabela 12. Redução da $\alpha$-trifluormetilcetona $\mathbf{1 5}$ com as algas marinhas $\quad 77$

Tabela 13. Redução da $\alpha$-trifluormetilcetona $\mathbf{1 6}$ com as algas marinhas 78 
Biocatalisadores de origem marinha (algas, bactérias e fungos) para redução estereosseletiva de cetonas

\section{Introdução}

Ana Maria Mouad

Orientador: Prof. Dr. André Luiz Meleiro Porto 
Nos últimos anos, a química tem evoluído de forma indiscutível em todas as suas áreas de atuação, contribuindo para os avanços tecnológicos. A grande maioria dos materiais e produtos utilizados pelo homem é confeccionada a partir de métodos que incluem transformações químicas. No entanto, a crescente demanda na síntese de substâncias orgânicas e inorgânicas ao longo dos anos, acarretou em um aumento na geração de subprodutos tóxicos que se reflete negativamente sobre o meio ambiente.

Desta forma, tornou-se fundamental a adoção de medidas ambientalmente adequadas, incentivando uma nova postura química, onde medidas de prevenção que minimizem riscos ao meio ambiente sejam aplicadas, seja no meio acadêmico ou no meio industrial (Silva, L.M., 2007). Neste contexto, uma extensão de rotas sintéticas empregando catalisadores naturais é atualmente uma das áreas mais importantes em síntese orgânica. Esta área é a biocatálise, a qual desenvolve transformações orgânicas em uma ou mais etapas, para a produção de substâncias bioativas com alto grau de pureza (Liljeblad, A. \& Kanerva, L.T., 2006).

Os termos biocatálise e biotransformação abrangem os processos em que enzimas são utilizadas para catalisar reações químicas, porém fora do sistema bioquímico, ou seja, com substratos não naturais às suas vias metabólicas. Associado a biocatálise, o termo biotransformação pode ser aplicado para modificações específicas ou interconversões realizadas por enzimas na estrutura química de compostos em múltiplas etapas (Molinari et al., 2007).

As enzimas fazem parte das células de organismos vivos como fungos filamentosos, algas, plantas, bactérias e leveduras, sendo também possível utilizá-las em formas isoladas provenientes de fontes comerciais. A utilização de catalisadores naturais na transformação de compostos orgânicos sintéticos é realizada há mais de 100 anos (Faber, 2004). No entanto, o desenvolvimento de biocatalisadores como 
ferramenta de síntese expandiu-se apenas ao longo das últimas décadas, associado ao conhecimento do modo de ação destes catalisadores biológicos, as enzimas.

\section{- Enzimas}

Enzimas são macromoléculas predominantemente protéicas, imprescindíveis a qualquer ser vivo. Como proteínas, são formadas por longas sequiências de aminoácidos que adotam complexas estruturas tridimensionais, responsáveis por sua função (Figura 1). Como importantes funções estão regular e manter processos vitais, além da capacidade de acelerar reações químicas, que, em sua ausência, ocorreriam muito lentamente ou nem mesmo ocorreriam. (Said, S. \& Pietro, R.C.L., 2004).
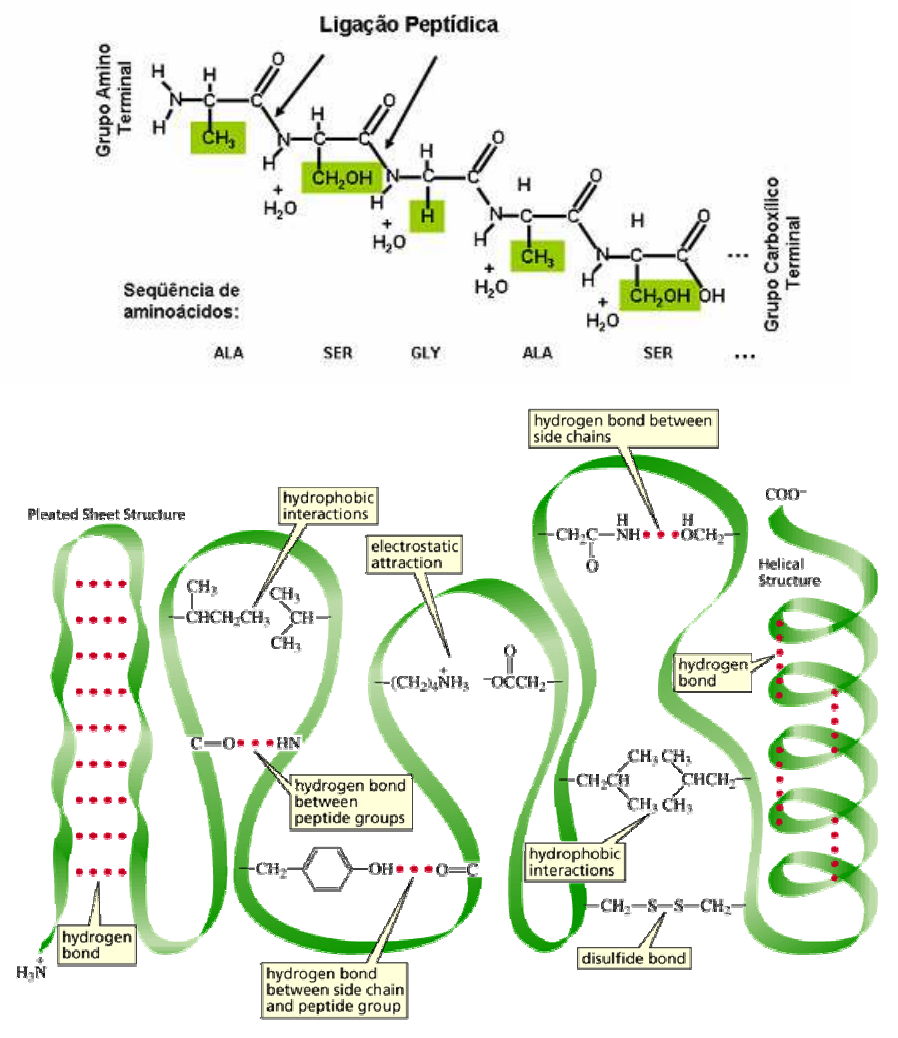

Figura 1. Estrutura primária de uma proteína (enzima). Estrutura tridimensional e suas interações (Dorn, 2008). 
A ação de uma enzima está sempre associada a um sítio ativo ou a um ponto para "prender" substratos através de forças intermoleculares, conferindo à enzima uma alta especificidade catalítica (Lehninger, 2000). Um de seus aspectos mais importantes para a química orgânica é a estereosseletividade das reações que catalisam. Todas as enzimas são formadas por L-aminoácidos sendo, portanto, catalisadores quirais que apresentam configurações e conformações pré-determinadas. Como consequiência, qualquer tipo de quiralidade presente na molécula de um substrato é "reconhecida" na formação do complexo enzima-substrato (Guthmann et al.,2002). Desta forma, as reações catalisadas pelas enzimas podem ser quimio- e/ou regiosseletivas, seja atuando preferencialmente sobre um grupo funcional de um substrato que contenha diferentes funções ou distinguindo entre posições de um grupo funcional em uma determinada molécula (Faber, 2004).
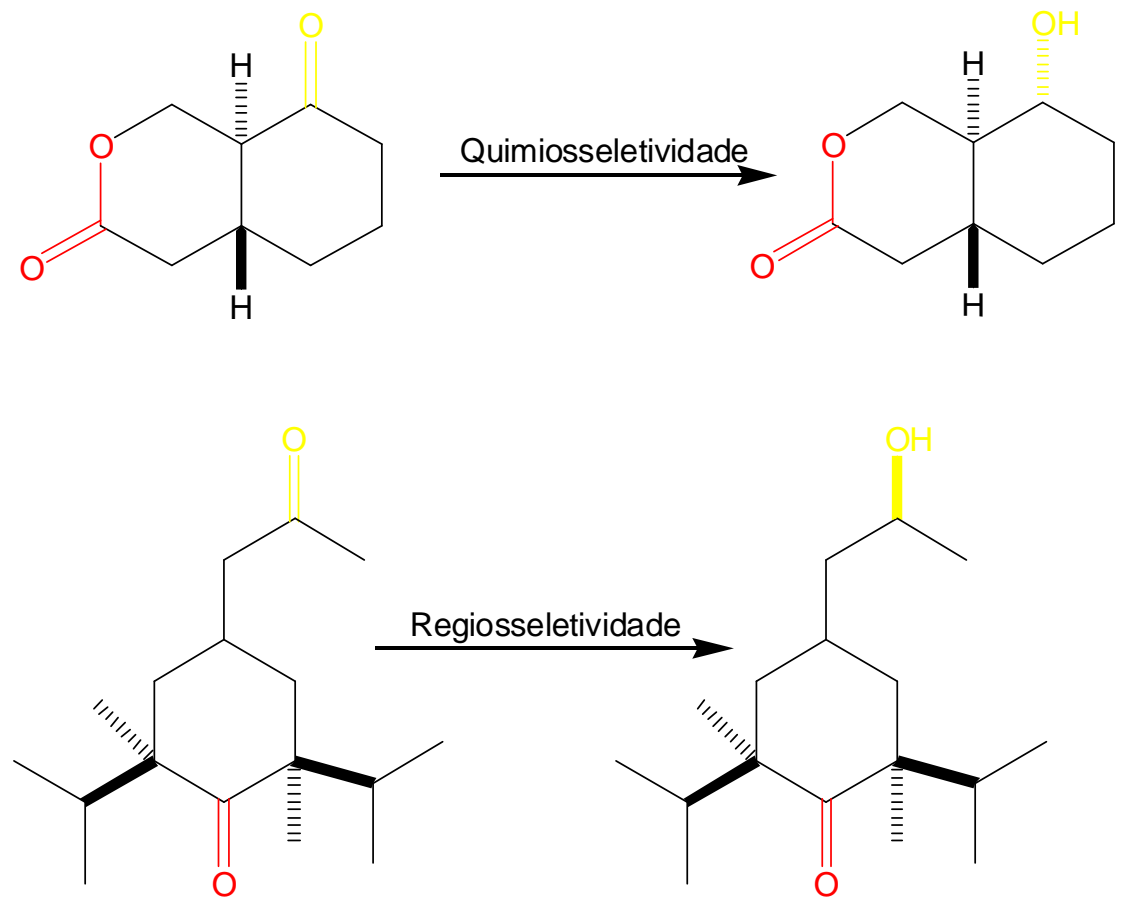

Figura 2: Exemplos de moléculas com diferentes grupos funcionais (quimiosseletividade), grupos funcionais iguais situados em diferentes regiões (regiosseletividade). 
Em compostos bioativos, tais como, produtos farmacêuticos e agroquímicos, a atividade biológica depende, em muitos casos de sua configuração absoluta. Normalmente um dos estereoisômeros apresenta atividade biológica, enquanto o outro é menos ativo, ou até mesmo tóxico ou inativo (Bonatto et al., 2000). Desta forma, através da ação seletiva de uma enzima, um composto proquiral pode ser transformado em uma substância opticamente ativa e ainda, com formação predominante de um estereoisômero. Uma vez que mais da metade de moléculas candidatas a fármacos possuem mais de um estereocentro, os biocatalisadores quirais assumem grande importância, justificando o fato de mais de $10 \%$ da produção mundial de fármacos ser obtida por processos bioenzimáticos (biocatálise e biotransformação), (Faber, 2004).

A importância da biocatálise no desenvolvimento de novos fármacos e agrotóxicos é bem conhecida e, uma variedade de enzimas já é comumente utilizada em processos industriais. Como exemplo, pode-se citar os processos de síntese dos fármacos efedrina, com atividade $\beta$-adrenérgica obtido pela levedura Saccharomyces cerevisae e dos antibióticos ampicilina e cefadroxil obtidos pela enzima penicilina acilase (De Conti, 2001).<smiles>CC(C)[C@H](O)c1ccccc1</smiles><smiles></smiles><smiles>CC1=C(C(=O)O)N2C(=O)[C@H](CC(=O)[C@@H](N)c3ccc(O)cc3)[C@H]2SC1</smiles>

Figura 3. Moléculas de efedrina, ampicilina e cefadroxil obtidas por biotransformações 
Além de atuarem na preparação de fármacos como precursores, compostos opticamente ativos são importantes na síntese de feromônios, aromas, fragrâncias, cosméticos e pesticidas (Utsukihara et al., 2006). Estes compostos podem ser obtidos por diferentes rotas enzimáticas, levando-se em conta a reação de interesse (hidrogenação, hidrólise, hidroxilação, redução, oxidações, entre outras) e a classe de enzimas necessárias para tais transformações. Até o presente momento, cerca de 3200 enzimas são reconhecidas pela União Internacional de Bioquímica (Faber, 2004). A União Internacional de Bioquímica e Biologia Molecular (UIBBM) classifica as enzimas em seis grupos e cada uma delas em subgrupos de acordo com o tipo de reação que catalisam (Tabela 1).

Tabela 1. Classificação das enzimas

\begin{tabular}{|c|c|c|c|c|}
\hline Número & Classes & Tipo de reação catalisada & Subclasse & Utilidade $^{\mathrm{a}}$ \\
\hline 1 & Oxidorredutases & $\begin{array}{l}\text { Oxidação-redução: oxigenação de } \\
\text { ligações C-H, C-C, C=C, ou remoção ou } \\
\text { adição de átomos de hidrogênio } \\
\text { equivalentes. }\end{array}$ & $\begin{array}{l}\text { Hidrogenases, oxidases, } \\
\text { peroxidades, redutases }\end{array}$ & $25 \%$ \\
\hline 2 & Transferases & $\begin{array}{l}\text { Reações de transferência de grupos } \\
\text { aldeídos, cetonas, metil, fosforil. }\end{array}$ & $\begin{array}{l}\text { Transaldolases, } \\
\text { transcetolases }\end{array}$ & $5 \%$ \\
\hline 3 & Hidrolases & $\begin{array}{l}\text { Formação de ésteres, aminas, } \\
\text { lactonas, epóxidos, nitrilas. }\end{array}$ & $\begin{array}{l}\text { Esterases, lipases, } \\
\text { peptidades, fosfatases }\end{array}$ & $60 \%$ \\
\hline 4 & Liases & $\begin{array}{l}\text { Adição-eliminação de pequenas } \\
\text { moléculas em ligações } \mathrm{C}=\mathrm{C}, \mathrm{C}=\mathrm{N} \text {, } \\
\mathrm{C}=\mathrm{O} \text {. }\end{array}$ & $\begin{array}{l}\text { Descarboxilases, } \\
\text { fosfatases }\end{array}$ & $7 \%$ \\
\hline 5 & Isomerases & $\begin{array}{l}\text { Transferência de grupos dentro da } \\
\text { molécula para produzir isômeros }\end{array}$ & $\begin{array}{l}\text { Racemases, } \\
\text { epimerases }\end{array}$ & $2 \%$ \\
\hline 6 & Ligases & $\begin{array}{l}\text { Formação e clivagem de ligações C- } \\
\text { C, C-S, C-O, C-N e ésteres de fosfato }\end{array}$ & Sintetases & $1 \%$ \\
\hline
\end{tabular}

${ }^{a}$ Utilidade estimada da classe de enzimas em transformações de substratos não naturais (Faber, 2004). 


\section{- Classes de enzimas e suas aplicações}

Em biocatálise, as principais reações promovidas são de hidrólise, pela facilidade no manuseio e estabilidade das enzimas hidrolases, especialmente as lipases e esterases, seguidas de reações de oxidação e redução (Matsuda et al., 2009). Indústrias de alimentos e de química fina são os principais mercados para a comercialização de enzimas oxidorredutases, no entanto, esta utilização é pequena comparada á das enzimas hidrolíticas (Xu, F., 2005). Com a diversidade de enzimas conhecidas, os processos biocatalíticos assumem importante papel em síntese orgânica de diversos compostos de interesse.

\section{- Vantagens na utilização de enzimas em reações biocatáliticas}

Além da grande diversidade enzimática, é conhecido que as enzimas atuam em condições reacionais brandas, como em temperaturas ambientes $\left(20^{\circ}-40^{\circ} \mathrm{C}\right)$ e em soluções com pH em torno de 5 - 8, fato que minimiza problemas reacionais de decomposição, isomerização, racemização, eliminação. Ainda, os processos mediados por enzimas são acelerados por um fator de $10^{8}-10^{12}$, comparados com processos em que não ocorrem cataliticamente por sua intermediação. Também, frente aos catalisadores sintéticos que contém metais pesados, os biocatalisadores enzimáticos são vantajosos, pois são ambientalmente aceitáveis, uma vez que são completamente biodegradáveis (Faber, 2004). O tipo de biocatalisador a ser utilizado nestas condições (enzimas isoladas, livres ou imobilizadas, células de micro-organismos) pode depender de alguns fatores como o tipo de reação, se haverá ou não necessidade de cofatores e a escala em que as biotransformações devem ser conduzidas. 
O procedimento mais comumente utilizado em biocatálise para a busca de novas enzimas é feito através de seleção de micro-organismos. Os micro-organismos neste caso são de particular interesse devido ao curto período de reprodução, a grande diversidade de processos metabólicos e enzimas envolvidas, além da diversidade de organismos na natureza que podem ser testados. Os micro-organismos modificam e degradam uma variedade de moléculas orgânicas, desde as mais simples até as mais complexas. Desta forma, é de se esperar que em experimentos de triagens pelo menos alguns apresentem capacidade para catalisar uma dada reação de interesse (De Conti et al., 2001).

Pode-se também utilizar enzimas puras, as quais são isoladas de diferentes fontes, muitas delas disponíveis comercialmente. Enzimas isoladas que atuam como biocatalizadores em reduções assimétricas são bem documentadas (Margolin,A.L., 1993). Apesar de enzimas isoladas serem mais ativas e seletivas do que as células íntegras de micro-organismos e plantas, sua recuperação e purificação pode ser extremamente cara, e em muitos casos necessitam de um ou mais cofatores para que as reações se processem (Faber, 2004), enquanto células totais oferecem benefícios de custo (Quezada, M.A., 2009). Algumas comparações entre a utilização de enzimas isoladas e células totais são apresentadas na tabela 2 . 
Tabela 2. Vantagens e desvantagens no uso de células totais ou enzimas isoladas (Faber, 2004)

\begin{tabular}{|c|c|c|c|c|}
\hline Biocatalisador & Forma & & Vantagens & Desvantagens \\
\hline \multirow[t]{4}{*}{$\begin{array}{l}\text { Enzimas } \\
\text { isoladas }\end{array}$} & Qualquer & & $\begin{array}{l}\text { Melhor produtividade devido a } \\
\text { maior tolerâncias de } \\
\text { concentrações }\end{array}$ & $\begin{array}{l}\text { Necessidade de } \\
\text { recuperação de } \\
\text { cofatores }\end{array}$ \\
\hline & $\begin{array}{l}\text { Dissolvida } \\
\text { água }\end{array}$ & em & Alta atividade enzimática & $\begin{array}{l}\text { Necessidade de } \\
\text { extração, possíveis } \\
\text { reações laterais }\end{array}$ \\
\hline & $\begin{array}{l}\text { Suspensa } \\
\text { solventes } \\
\text { orgânicos }\end{array}$ & em & $\begin{array}{l}\text { Fácil manipulação, Fácil } \\
\text { recuperação da enzima }\end{array}$ & Atividade reduzida \\
\hline & Imobilizada & & Fácil recuperação da enzima & $\begin{array}{l}\text { Perda de atividade } \\
\text { durante imobilização }\end{array}$ \\
\hline \multirow[t]{3}{*}{ Células totais } & Qualquer & & $\begin{array}{l}\text { Não há necessidade de } \\
\text { recuperação de cofatores }\end{array}$ & $\begin{array}{l}\text { Equipamentos caros e } \\
\text { baixa produtividade }\end{array}$ \\
\hline & $\begin{array}{l}\text { Células em } \\
\text { crescimento }\end{array}$ & & Alta atividade & $\begin{array}{l}\text { Formação de } \\
\text { subprodutos }\end{array}$ \\
\hline & $\begin{array}{l}\text { Células } \\
\text { imobilizadas }\end{array}$ & & Reutilização de células & Baixa atividade \\
\hline
\end{tabular}

\section{- Cofatores}

Algumas enzimas necessitam da presença de um cofator para exercer sua função. Cofatores podem ser íons metálicos como zinco e magnésio, ou podem ser moléculas orgânicas, chamadas coenzimas. Em ambos os casos, atuam em conjunto com as enzimas para catalisar as reações. Dentre as coenzimas, os grupos mais importantes são os constituídos pelo NADH, NADPH, ATP, ADP e coenzima A, que atuam como co-substratos, sendo sua atividade regenerada após sua participação na reação enzimática (Said, S. \& Pietro, 
R.C.L., 2004). Desidrogenases, redutases, oxidases e oxigenases requerem coenzimas, tais como, NADH e NADPH (Matsuda et al., 2009). As moléculas de Dinucleotídeo de Nicotinamida e Adenina (NADH) e o Fosfato de Dinucleotídeo de Nicotinamida e Adenina (NADPH) são importantes coenzimas, tendo ação catalítica em diversos processos enzimáticos. (Figura 4).
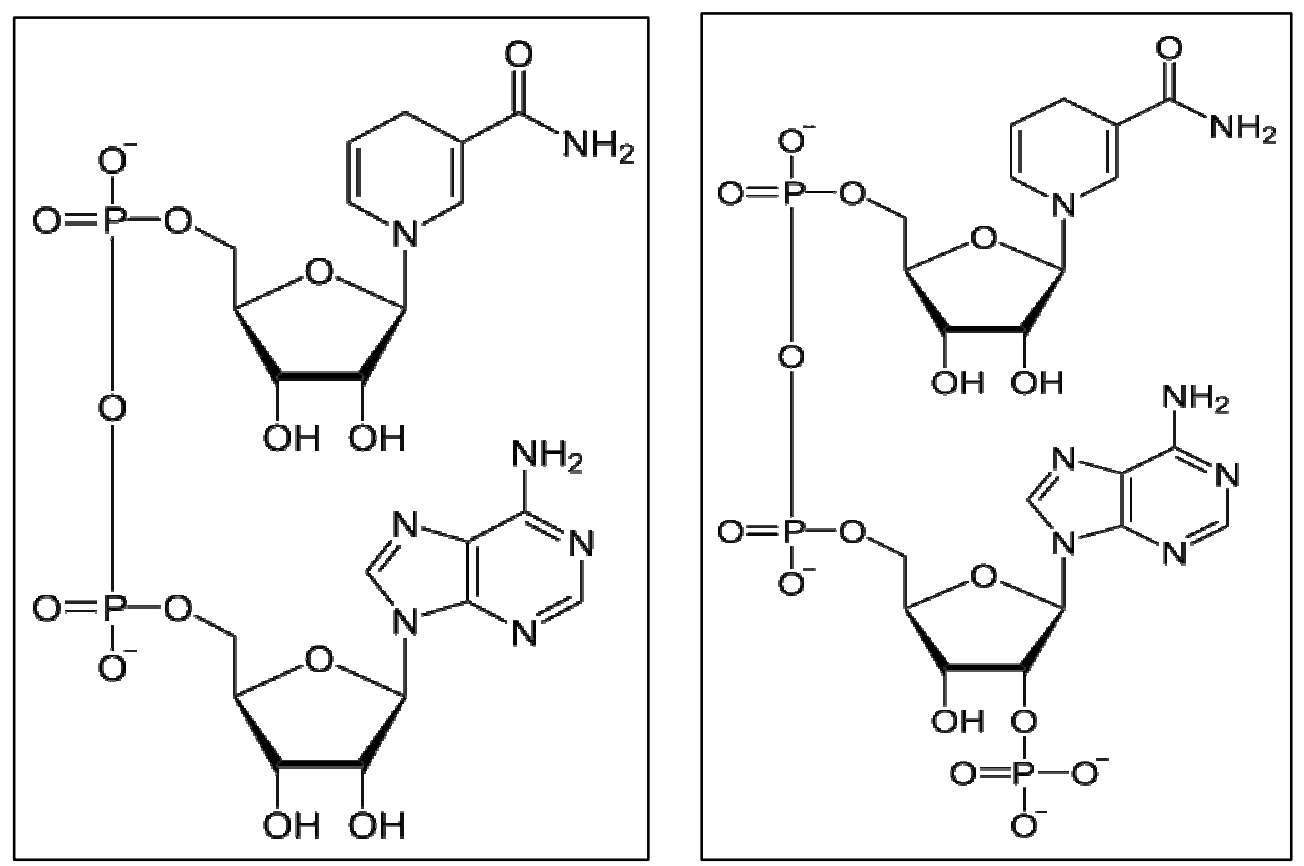

Figura 4: Coenzimas NADH e NADPH

\section{- Coenzimas e sua participação em reduções de cetonas}

No caso de reações em que a presença de coenzimas é necessária, as reações de redução de cetonas ocorrem, resumidamente, nas seguintes etapas (Matsuda et al., 2009):

1- Coenzima e substrato se ligam a uma enzima;

2- O substrato é reduzido, enquanto a coenzima é oxidada;

3- A coenzima e o produto são dissociados da enzima. 
Quando uma enzima, como a álcool desidrogenase reduz o grupo carbonílico usando a coenzima NADPH ou NADH, esta discrimina entre as duas faces do grupo presente no substrato, de tal forma que durante a transformação pode existir a predominância na formação de um dos estados estereoisoméricos (Drauz, K. \& Waldmann, H.,1995). Exemplo de enzima que necessita de um cofator e de uma coenzima, a álcool desidrogenase, na catálise de formação de alcoóis a partir da redução de grupos carbonílicos, utiliza íons zinco no sítio ativo do grupo catalítico. Esta enzima catalisa a transferência de um hidreto da coenzima NADH, para uma variedade de grupos carbonílicos de aldeídos e cetonas (Nakamura et al., 2003). Alguns mecanismos têm sido propostos para sua ação catalítica, muitos deles incluindo a interação do oxigênio carbonílico do substrato coordenado ao átomo de zinco, onde este atuaria como um ácido de Lewis recebendo a densidade eletrônica (Figura 5). Desta forma, além da coenzima, está atuando também no sítio catalítico o íon zinco e outros resíduos de aminoácidos. Uma vez que o substrato esteja coordenado no sítio catalítico da enzima, ocorre a transferência de um dos íons hidreto do cofator para uma das faces do grupo carbonílico (Figura 5). 

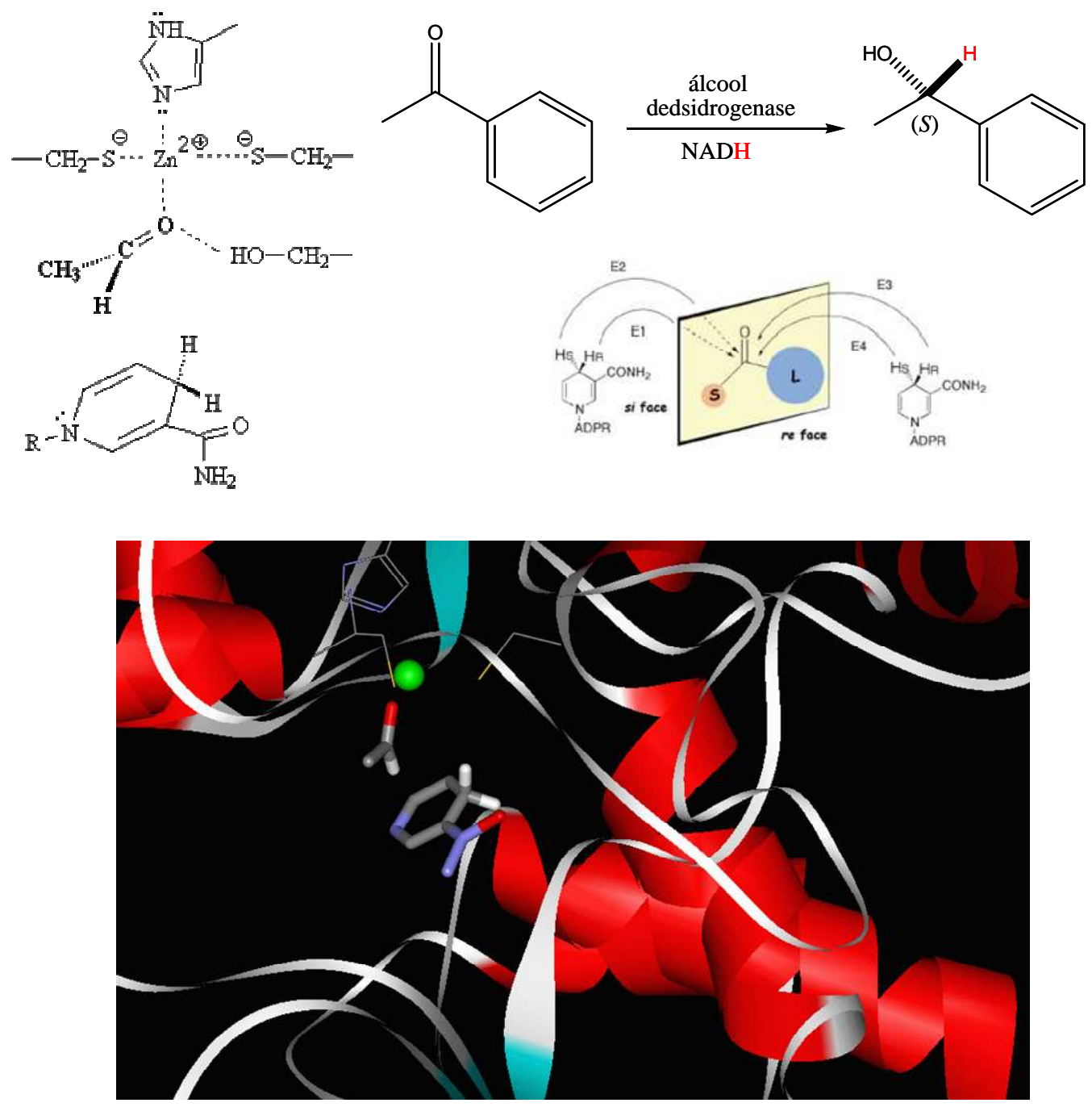

Figura 5. Transferência de íon hidreto do cofator NAD $(\mathrm{P}) \mathrm{H}$ ao grupo carbonílico,

o sítio ativo de uma álcool desidrogenase

Uma importante ferramenta empírica para a determinação da estereoquímica de compostos carbonílicos, reduzidos biocataliticamente é a regra de Prelog (Musa et al., 2007).

\section{- Regra de Prelog}

Foi postulado por Prelog que de acordo com o tamanho (volume) dos grupos substituintes ligados ao carbono carbonílico é possível inferir por qual face da carbonila ocorre transferência do íon hidreto. As duas faces de um centro trigonal plano, por 
exemplo, de um grupo carbonílico, têm as designações face re e face si, estabelecidos de acordo com as prioridades por número atômico segundo Cahn-Ingold-Prelog para os grupos ligados ao centro trigonal plano. Se a transferência ocorrer pela face re da carbonila obtém-se $(S)$-álcoois e se ocorrer pela face si obtém-se $(R)$-álcoois. Deve-se ainda considerar que os grupos oxigênio $(\mathrm{O})$, o grupo volumoso e o grupo pequeno seguem a mesma prioridade segundo Cahn-Ingold-Prelog para a designação da configuração absoluta dos centros estereogênicos, respectivamente.

\section{- Redução de cetonas para obtenção de alcoóis quirais}

A redução assimétrica de cetonas é uma das mais importantes, fundamentais e práticas reações para a produção de alcoóis quirais, os quais podem ser transformados em várias outras funcionalidades, sem racemização e serem utilizados para sintetizar importantes produtos químicos de interesse industrial (Nakamura et al., 2003). Dentre os diversos ramos industriais em que os alcoóis quirais despertam interesse, como agroquímico, alimentício e cosmético, a indústria farmacêutica se destaca por uma busca crescente em sintetizar fármacos através de rotas alternativas, ambientalmente aceitáveis e economicamente mais interessantes. Os alcoóis quirais, neste caso, são obtidos via reações de redução de cetonas empregando como catalisadores microorganismos ou enzimas isoladas. Estes alcoóis atuam então como importantes precursores para posterior obtenção dos fármacos de interesse. Um interessante exemplo a ser citado é a síntese do composto LY300164 utilizado em testes para o tratamento de doenças como mal de Parkinson e esclerose lateral amiotrófica (ELA). Este composto é obtido a partir do precursor 4-(3,4-metilenodioxifenil)-2-propanol, um álcool quiral. 
<smiles>CC(=O)Cc1ccc2c(c1)OCO2</smiles>

cetona

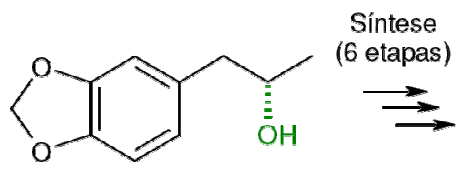

álcool quiral

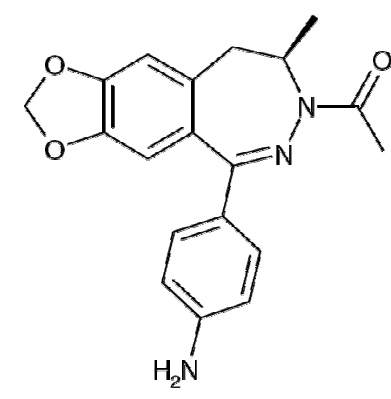

LY300164

Figura 6. Redução de uma cetona através de um micro-organismo para obtenção de um álcool quiral, precursor na síntese de um fármaco.

\section{- Redução de cetonas com micro-organismos- Revisão Bibliográfica}

Em biocatálise, as reduções de grupos carbonílicos podem ser obtidas através de diversos organismos vivos. Um dos primeiros micro-organismos utilizados como fonte enzimática para reações de redução de cetonas foi a levedura Saccharomyces cerevisiae, conhecida por fermento de pão. Uma diversidade de cetonas alifáticas e aromáticas foi reduzida em seus respectivos $(S)$-alcoóis, como mostra a tabela 3 (Faber, 2004).

Tabela 3. Redução de cetonas alifáticas e aromáticas com S. cerevisae (Faber, 2004)

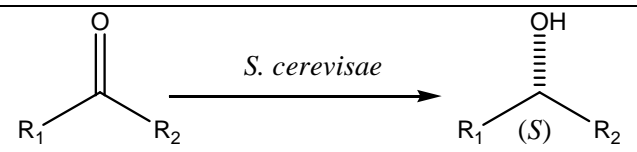

\begin{tabular}{cccc}
\hline $\mathbf{R}_{\mathbf{1}}$ & $\mathbf{R}_{\mathbf{2}}$ & $\begin{array}{c}\text { Configuração } \\
\text { absoluta }\end{array}$ & ee (\%) \\
\hline $\mathrm{Me}$ & $\mathrm{CF}_{3}$ & $S$ & $>80$ \\
$\mathrm{CF}_{3}$ & $\mathrm{CH}_{2}-\mathrm{Br}$ & $S$ & $>80$ \\
$\mathrm{Me}$ & $n-\mathrm{Bu}$ & $S$ & 82 \\
$\mathrm{Me}$ & $\mathrm{Ph}$ & $S$ & 89 \\
$\mathrm{Me}$ & $\mathrm{CH}_{2}-\mathrm{OH}$ & $S$ & 91 \\
$\mathrm{Me}$ & $\left(\mathrm{CH}_{2}\right)_{2}-\mathrm{CH}=\mathrm{C}\left(\mathrm{CH}_{3}\right)_{2}$ & $S$ & 94 \\
$\mathrm{Me}$ & $\mathrm{C}\left(\mathrm{CH}_{3}\right)_{2}-\mathrm{NO}_{2}$ & $S$ & $>96$ \\
\hline
\end{tabular}


O sucesso em reações com células inteiras da levedura S. cerevisae levou a uma busca por novos biocatalisadores. Estudos realizados com a levedura Candida magnoliae e a bactéria Lactobacillus kefir demonstraram que estes micro-organismos possuem em seus sistemas biológicos enzimas carbonil-redutases que foram estereosseletivas nas reduções de derivados de acetofenonas (Matsuda et al., 2009), (Figura 7).

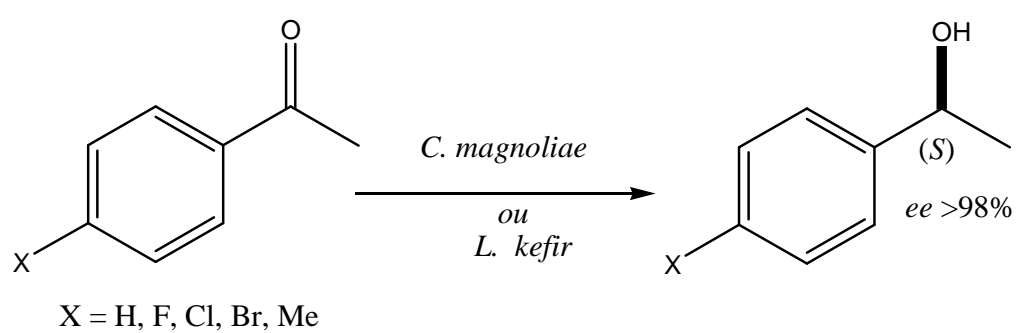

Figura 7. Redução de $p$-acetofenonas com Candida magnoliae ou Lactobacilus kefir

Estes são dois exemplos de estudos sobre o potencial biocatalisador de alguns micro-organismos em reduções de cetonas. A diversidade de micro-organismos tanto terrestres quanto marinhos a ser explorada é imensa. Os oceanos, habitats que preservam a maioria de suas características naturais e que são auto-suficientes, representam metade da biodiversidade global (Cooper, 2004). No entanto, os microorganismos marinhos são relativamente pouco explorados em processos biocatalíticos. Os micro-organismos atualmente recebem o foco principalmente de estudos visando à descoberta de substâncias potencialmente bioativas. Estudos de reduções biocatalíticas de cetonas aromáticas substituídas em posições orto, meta e para com algas vermelhas Cyanidioschyzon merolae e Cyanidium caldarium forneceram exclusivamente $(S)$ alcoóis com diferentes seletividades (Utsukihara et al., 2006), (Figura 6). As células íntegras da alga $C$. merolae apresentam vantagens únicas, pois não possuem paredes celulares rígidas, permitindo maiores interações entre as enzimas e os substratos. 


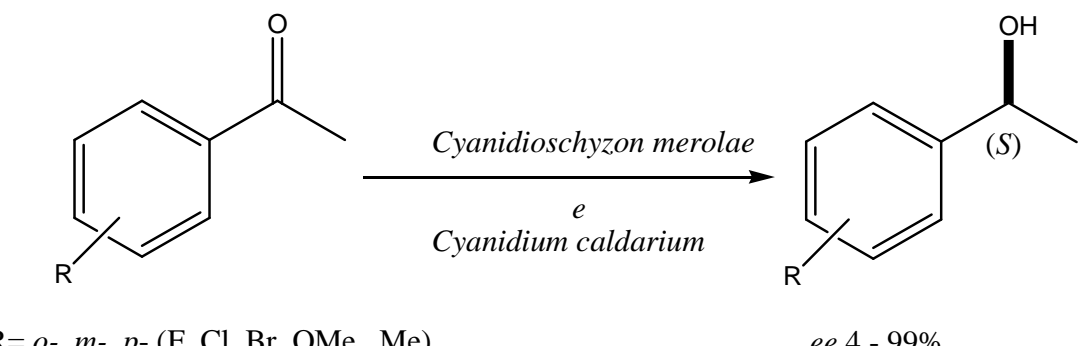

$\mathrm{R}=o^{-}, m-, p-(\mathrm{F}, \mathrm{Cl}, \mathrm{Br}, \mathrm{OMe}, \mathrm{Me}) \quad e e 4-99 \%$

Figura 8. Redução de derivados de acetofenonas com as

algas C. merolae e C. caldarium

As reduções das cetonas contendo flúor, cloro e bromo com as espécies Cyanidioschyson merolae e Cyanidium caldarium ocorreram com boas enantiosseletividades (67 - 99\%) e observou-se que as conversões elevaram-se com o aumento do tamanho dos elementos halogenados. Em contraste, as reduções de metil- e metoxiacetofenonas foram obtidas com baixos rendimentos $(7-38 \%)$ e baixas enantiosseletividades $(2-41 \%)$. Neste mesmo estudo com as algas $C$. merolae e $C$. caldarium, canforquinonas e cetonas esteroidais foram reduzidas seletivamente (Utsukihara et al., 2006). Estudos realizados com a cianobactéria Synechococus sp demonstraram que este organismo reduziu várias arilmetilcetonas em seus correspondentes $(S)$-alcoóis. Neste mesmo estudo, a pentafluoracetofenona foi completamente consumida após três dias de reação no correspondente $(S)$-álcool em bom rendimento (90\%) e excelente excesso enantiomérico (99\%), (Figura 9).<smiles>CC(=O)c1c(F)c(F)c(F)c(F)c1C(C)=O</smiles>

Figura 9. Redução assimétrica da pentafluoracetofenona com Synechococus sp. 
Entre as vantagens do uso de cianobactérias em biotransformação, além da alta enantiosseletividade, estão facilidade de manipulação e altos índices de crescimento destes organismos, no entanto, apresentam como desvantagem a dificuldade de sua preservação. Apesar deste fato, para que reações de redução ocorram não são requeridas grandes quantidades de biocatalizadores (Nakamura et al., 2003).

A alga marinha Spirulina platensis teve seu potencial biocatalisador estudado em reações com $\alpha$-bromocetonas cíclicas e aromáticas. Biotransformações das cetonas alifáticas, 3-bromo-4-heptanona e 4-bromo-5-nonanona com a alga S. platensis resultaram em correspondentes $\alpha$-hidróxi-compostos com boas conversões, 91 e $60 \%$ respectivamente (Utsukihara et al., 2007).<smiles>[R]CCC(=O)C(O)CCPC#CCCCCC(Br)C(=O)CC[R]</smiles>

Figura 10. Biotransformação de $\alpha$-bromocetonas com S. platensis

Em estudos realizados com a alga Dunaliella salina, o composto $\alpha$ hidroxicetona foi reduzido ao $(R)$-(-)-1,2-propanodiol com excesso enantiomérico de 75\%. A bioconversão conduzida na presença de 3-(3,4-diclorofenil)-1,1-dimetiluréia demonstrou que a coenzima NADPH foi regenerada e, que a concentração do álcool obtida foi superior a 95\% sem formação de subprodutos ou biodegradação (Hatanaka et al., 1996).

Reações da cetona 3-acetil-5-propilisoxasol foram realizadas com a alga Synechocccus elongatus PCC 7942. O substrato foi suspenso e mantido sob agitação, e não foram observadas conversões. As reações foram então conduzidas sob iluminação 
fluorescente e após 96 horas, a cetona foi convertida em $67 \%$ no respectivo $(S)$-álcool, apresentando 99\% de excesso enantiomérico (Itoh et al., 2005).

Cinco espécies de algas marinhas Chlorella minutíssima, Nannochloris atomus, Dunaliella parva, Porphyridium purpureum e Isochrys galbana foram estudadas em reações de biotransformações com cetonas aromáticas (Hook et al.), (Tabela 4).

Tabela 4. Redução de cetonas (\%) com algas marinhas.

\begin{tabular}{|c|c|c|c|c|c|}
\hline Composto & C. minutíssima & $\begin{array}{c}N . \\
\text { atomus }\end{array}$ & $\begin{array}{c}D . \\
\text { parva }\end{array}$ & $\begin{array}{c}P . \\
\text { purpureum }\end{array}$ & $\begin{array}{c}I . \\
\text { galbana }\end{array}$ \\
\hline acetofenona & 65 & 90 & 21 & 97 & 64 \\
\hline$p$-cloroacetofenona & 36 & 28 & 21 & 53 & 99 \\
\hline$p$-metilacetofenona & 60 & 66 & 35 & 75 & 4 \\
\hline$p$-hidroxiacetofenona & 0 & 0 & 0 & 0 & 0 \\
\hline benzofenona & 0 & 0 & 0 & 0 & 0 \\
\hline
\end{tabular}

Neste estudo, os rendimentos variaram conforme a estrutura dos substratos, bem como o tipo de alga utilizada. Este fato demonstra o quanto triagens com diferentes espécies tornam-se importantes.

Pesquisas demonstraram também que algas e fungos filamentosos marinhos apresentam alta capacidade de biodegradar compostos fenólicos em sua estrutura, os quais são poluentes em ambientes marinhos (Lika \& Papadakis, 2009). No caso de algas marinhas, estas podem ser citadas como importantes fontes de substâncias antioxidantes naturais, uma vez que realizam fotossíntese e têm sistemas de defesas bem desenvolvidos (Rocha et al, 2007), apresentando importância do ponto de vista econômico e ambiental para a sociedade humana. Ainda, realizam manutenção do equilíbrio biológico nos ambientes aquáticos, ocasionando a continuidade da fauna existente, a qual pode ser utilizada pelo homem como fonte de matéria prima Vidotti \& 
Rollemberg, 2004). No contexto deste trabalho, as algas marinhas são de particular interesse devido à grande diversidade de processos metabólicos e alta produção enzimática.

Sendo o Brasil um país-continente rico em recursos aquáticos, as algas marinhas e os micro-organismos marinhos podem ser intensamente explorados para a aplicação em reações de biocatálise, especialmente reações de redução de cetonas. Diferentes espécies de algas e fungos marinhos apresentaram-se como ótimos biocatalizadores para obtenção de (S)-alcoóis (Itoh et al., 2005 Nakamura et al., 2000).

Neste trabalho foram realizadas reações de redução de cetonas com fungos marinhos e com as espécies de algas marinhas Bostrychia radicans e Bostrychia tenella. No Laboratório de Química Orgânica do Ambiente Marinho (Departamento de Física e Química da Faculdade de Ciências Farmacêuticas de Ribeirão Preto - USP) têm sido estabelecidas, sob a responsabilidade da Profa. Dra. Hosana M. Debonsi, culturas axênicas, além de estudos químicos e biológicos de algas pertencentes ao gênero Bostrychia. Até o presente momento, foram constatadas atividades tripanocida (Trypanosoma cruzi), citotóxica (Artemia salina Leach.), antifúngica (Cladosporium cladosporioides, Cladosporium sphaerospermum) e antitumoral para os extratos e frações provenientes de $B$. radicans, o que nos sugere a possibilidade de potencial biológico para as substâncias acumuladas nesta espécie. O emprego de algas marinhas em biocatálise é pouco usual na literatura e estas fontes enzimáticas vêm demonstrando excelente potencial biocatalítico. Desta forma, tornam-se fundamentais os estudos nas áreas ligadas à utilização das algas e microrganismos marinhos para que as propriedades destes possam ser plenamente aproveitadas. 
Biocatalisadores de origem marinha (algas, bactérias e fungos) para redução estereosseletiva de cetonas

\section{Materiais e métodos}

Ana Maria Mouad

Prof. Dr. André L. M. Porto 


\section{MATERIAIS}

Reagentes e solventes

Para o desenvolvimento do trabalho envolvendo a redução enzimática com os biocatalisadores de origem marinha foram utilizadas cetonas comerciais adquiridas da empresa Sigma-Aldrich (Figura 1). Os solventes (acetato de etila, hexano, etc) foram adquiridos da marca Synth, Vetec, Merck e Tedia.<smiles>CC(=O)c1ccccc1I</smiles>

1-(2-iodofenil)etanona (1)<smiles>CC(=O)c1ccccc1F</smiles><smiles>CC(=O)c1ccccc1Cl</smiles>

1-(2-fluorfenil)etanona (7) 1-(2-clorofenil)etanona (8)<smiles>O=C(CC(=O)C(F)(F)F)c1ccco1</smiles>

4,4,4-triflúor-1-(furan-2-il)-butan-1,3-diona (15)<smiles>CC(=O)c1ccc(I)cc1</smiles>

1-(4-iodofenil)etanona (3)

1-(3-iodofenil)etanona (2)<smiles>CC(=O)c1ccccc1Br</smiles><smiles>CC(=O)c1ccccc1[N+](=O)[O-]</smiles>

1-(2-bromofenil)etanona (9) 1-(2-nitrofenil)etanona (10)<smiles>O=C(CC(=O)C(F)(F)F)c1ccc2ccccc2c1</smiles>

4,4,4-triflúor-1-(naftalen-2-il)-butan-1,3-diona (16)

Figura 1. Cetonas utilizadas nas reações de biorredução 
Os alcoóis racêmicos foram preparados de acordo com o seguinte procedimento: Em um balão de $25 \mathrm{~mL}$ sob agitação magnética e à temperatura ambiente adicionou-se metanol $(5 \mathrm{~mL})$, cetona $(50 \mathrm{mmol})$ e um excesso de borohidreto de sódio. A reação foi monitorada por cromatografia em camada delgada utilizando placas de sílica gel e em seguida revelada em solução de anisaldeído/ácido sulfúrico/ácido acético (1 mL/1 mL/100 mL). Após a reação ser completada adicionou-se água destilada (1 mL) e o metanol foi evaporado sob vácuo no rotaevaporador. Em seguida, adicionou-se $15 \mathrm{~mL}$ de água destilada e extraiu-se com acetato de etila $(3 \times 20 \mathrm{~mL})$. À fase orgânica adicionou-se sulfato de sódio, filtrou-se e concentrou-se sob vácuo no rotoevaporador. O produto foi purificado por cromatografia em coluna utilizando sílica gel com misturas de eluentes (hexano/acetato de etila). O rendimento das reações foi superior a $90 \%$. Análises por CG utilizando coluna quiral de ciclodextrina mostrou a resolução enantiomérica de todos os alcoóis. Os alcoóis derivados do feniletanol (4-6 e 11- 14) foram analisados por CG e caracterizados anteriormente pelo grupo (Kagohara et al., 2008; Da Rocha, 2008; Comasseto et al., 2006; Andrade et al., 2005; Comasseto et al., 2003). Os alcoóis $\mathbf{1 7}$ - $\mathbf{1 8}$ estão sendo caracterizados por RMN. Na figura 2 têm-se as estruturas dos alcoóis racêmicos preparados. 
<smiles>CC(O)c1ccccc1I</smiles>

1-(2-iodofenil)etanol (4)<smiles>CC(O)c1cccc(I)c1</smiles>

1-(3-iodofenil)etanol (5)<smiles>CC(O)c1ccc(I)cc1</smiles>

1-(4-iodofenil)etanol (6)<smiles>CC(O)c1ccccc1F</smiles><smiles>CC(O)c1ccccc1Cl</smiles><smiles>CC(O)c1ccccc1Br</smiles><smiles>CC(O)c1ccccc1[N+](=O)[O-]</smiles>

1-(2-fluorfenil)etanol (11) 1-(2-clorofenil)etanol (12) 1-(2-bromofenil)etanol (13) 1-(2-nitrofenil)etanol (14)<smiles>O=C(CC(O)C(F)(F)F)c1ccco1</smiles>

4,4,4-triflúor-1-(furan-2-il)-3-hidroxibutan-1-ol (17)<smiles>O=C(CC(O)C(F)(F)F)c1ccc2ccccc2c1</smiles>

Figura 2. alcoóis racêmicos

\section{Algas Bostrychia tenella e Bostrychia radicans}

A coleta das algas $B$. tenella e $B$. radicans foi realizada pela Profa. Dra. Hosana M. Debonsi da Faculdade de Ciências Farmacêuticas de Ribeirão Preto (FCFRP/USP). A identificação das espécies foi realizada pela Dra. Nair S. Yokoya do Instituto de Botânica de São Paulo (IB/SP). As algas foram coletadas em setembro de 2007 no Manguezal da Praia Brava em Ubatuba, litoral de Norte do Estado de São Paulo. Foram coletados $2 \mathrm{Kg}$ de algas, as quais foram armazenadas separadamente em pequenas porções em embalagens plásticas sob refrigeração em sacos plásticos $\left(-14{ }^{\circ} \mathrm{C}\right)$. 
As algas foram descongeladas em refrigerador sob temperatura de $4{ }^{\circ} \mathrm{C}$, mantendo-as embaladas e imersas em água destilada. Em seguida foram lavadas em água do mar artificial $(\mathrm{pH}$ 8) e imersas por $30 \mathrm{~s}$ em solução de hipoclorito de sódio 0,01\% e por fim, lavadas com água destilada. Em seguida em frascos erlenmeyers adicionaram-se $100 \mathrm{~mL}$ de água esterilizada $(\mathrm{pH}$ 8) e $5 \mathrm{~g}$ das algas $B$. tenella e $B$. radicans. A mistura foi mantida sob agitação orbital $\left(150 \mathrm{rpm}, 32^{\circ} \mathrm{C}, 5\right.$ dias $)$. A seguir transferiram-se com uma alça de inoculação porções do caldo contendo fragmentos de alga para placas de Petri contendo meio de cultura de extrato de malte $2 \%$. As placas foram mantidas em estufa $\left(\sim 30{ }^{\circ} \mathrm{C}\right)$ onde observou-se o crescimento dos microorganismos por um período máximo de 8 dias. Utilizou-se extrato de malte $2 \%$ com o objetivo de isolar linhagens fúngicas. Entretanto, foi observado o crescimento uniforme de uma colônia de bactéria filamentosa para os inóculos provenientes das algas $B$. tenella e B. radicans. As bactérias foram nomeadas de Bt-01 e Br-01 e estão sendo identificadas no Centro de Pesquisas Químicas, Biológicas e Agrárias (CPQBA/UNICAMP) pela Dra. Fabiana Fantinatti-Garboggini.

Isolamento de fungos da alga Sargassum sp.

A coleta da alga Sargassum sp. e o isolamento dos fungos foram realizados pelo grupo do Prof. Dr. Roberto G. S. Berlinck (IQSC/USP) e da Profa. Dra. Mirna H. R. Seleghim (UFSCar). A alga Sargassum sp. utilizada neste trabalho foi coletada em São Sebastião/SP e em janeiro de 2007. O material biológico foi colocado em sacolas de plástico esterilizadas, as quais foram imediatamente transportadas para o laboratório de 
apoio nas dependências do Centro de Biologia Marinha (CEBIMar/USP). Os talos das algas foram submetidos à esterilização superficial através de sucessivas lavagens com solução de 0,001 g.L $\mathrm{L}^{-1}$ de $\mathrm{HgCl}_{2}$ em etanol $5 \%$ por 1 minuto, seguido de três lavagens com água estéril.

Após a esterilização superficial foram realizados três procedimentos diferentes de inóculos, em todos os casos foram utilizados meios de cultura apropriados para o crescimento de fungos.

(a) $\mathrm{O}$ primeiro inóculo consistiu em transferir fragmentos da alga $\left(1 \mathrm{~cm}^{2}\right)$ para placas de Petri contendo dois meios de cultura (Malte 2\% e GPY).

(b) O segundo inóculo consistiu em triturar a alga em água destilada estéril obtendo-se um extrato aquoso, o qual foi inoculado em placas de Petri tanto sem diluição, quanto diluído para $10^{-2}$ nos meios de cultura de malte $2 \%$ e GPY.

(c) O terceiro procedimento realizou-se um esfregaço dos fragmentos da alga na superfície dos meios de cultura de malte $2 \%$ e GPY.

Todos os meios de cultura foram preparados com água do mar artificial esterilizada. Após a inoculação nas placas de Petri no laboratório do CEBIMar (USP), estas foram levadas para o Laboratório de Microbiologia da Universidade Federal de São Carlos (UFSCar) e incubadas em uma estufa $\left(25^{\circ} \mathrm{C}\right)$ por 7 dias. O isolamento dos fungos foi realizado pela Profa. Dra. Mirna H. R. Seleghim e pela Mestranda Stelamar Romminger (Stelamar, 2008).

A composição dos meios de cultura utilizados para os inóculos foram o meio GPY [glicose $(1 \mathrm{~g})$, peptona de carne de soja $(0,5 \mathrm{~g})$, extrato de levedura $(0,1 \mathrm{~g})$, agar (15 g), água do mar artificial (1 L)] e o meio de MA2 [extrato de malte (2 g), agar (15 g), água do mar artificial (1L)]. 
As placas foram examinadas a intervalos regulares para facilitar o isolamento das linhagens de fungos que cresceram a partir dos fragmentos e extratos da alga. A purificação das linhagens isoladas foi realizada pelo método de esgotamento por estrias em placas de Petri contendo meio agarizado, por sucessivos repiques até obter-se as colônias puras. Estas colônias foram caracterizadas de acordo com suas principais características macroscópicas: coloração da colônia, aspecto algodonoso ou pulvurulento e pela presença de presença de micélio aéreo.

Em seguida as colônias foram nomeadas de acordo com os critérios:

a) organismo a partir do qual as linhagens foram isoladas;

b) meio de cultura original do isolamento;

c) método de isolamento;

d) linhagem.

Os fungos foram nomeados de SMA2-C, SMA2-8, SMA2-58 e SGPY-41 e estão sendo identificados no Centro de Pesquisas Químicas, Biológicas e Agrárias (CPQBA/UNICAMP) pela Dra. Lara D. Sette.

Isolamento de fungos da alga Bostrychia radicans

O isolamento dos fungos endofíticos foi realizado pelos alunos do grupo de pesquisa do Laboratório de Química Orgânica do Ambiente Marinho (FCFRP/USP), sob a orientação da Profa. Dra. Hosana M. Debonsi.

A alga $B$. radicans foi lavada com água do mar para remoção de impurezas (areia, folhas). A desinfecção superficial deste material para o isolamento dos microorganismos foi realizada por três diferentes metodologias:

(a) Incubação em etanol $70 \%$ por 15 segundos e três lavagens em água do mar 
esterilizada.

(b) Incubação em etanol $70 \%$ por 10 segundos, incubação em hipoclorito de sódio $0,01 \%$ por 5 segundos e três lavagens em água do mar esterilizada.

(c) Incubação em etanol $70 \%$ por 5 segundos, incubação em hipoclorito de sódio $0,01 \%$ por 15 segundos e três lavagens em água do mar esterilizada.

As amostras esterilizadas foram fragmentadas com uso de pinça e bisturi cirúrgico estéreis e os fragmentos foram transferidos para placas de Petri com meios de cultivo sólidos de agar-alga e batata-dextrose-agar (BDA).

O meio agar-alga foi preparado pesando-se $20 \mathrm{~g}$ de alga $B$. radicans, os quais foram fragmentados em liquidificador com $200 \mathrm{~mL}$ de água do mar esterilizada. Em seguida foram adicionados cloranfenicol $(200 \mathrm{mg})$, agar (15 g) e água do mar (1 L). As placas foram incubadas em estufa a $28^{\circ} \mathrm{C}$ e os micro-organismos que se desenvolveram nas placas foram sucessivamente repicados até a obtenção das linhagens puras. Algumas linhagens foram avaliadas frente às reduções de cetonas. Os fungos foram nomeados de Br-09, Br-23, Br-27 e Br-53 e estão sendo identificados no Centro de Pesquisas Químicas, Biológicas e Agrárias (CPQBA/UNICAMP) pela Dra. Lara D. Sette.

\section{Fungos marinhos}

Os fungos marinhos foram isolados das esponjas Chelonaplysilla erecta e Geodia corticostylifera os quais fazem parte da coleção do Prof. Dr. Roberto G. S. Berlinck (IQSC). O isolamento foi realizado pelo grupo da Profa. Dra. Mirna H. R. Seleghim e as cepas encontram-se depositadas no laboratório de Microbiologia (UFSCar). A identificação das espécies foi realizada pela Dra. Lara D. Sette (curadora (CBQBA/UNICAMP) (Da Rocha et al., 2009). 
Meio líquido de extrato de malte 2\% (MA2): em frascos erlenmeyers de $250 \mathrm{~mL}$ foram adicionados água do mar artificial $(100 \mathrm{~mL})$ e extrato de malte $(2 \mathrm{~g}) . \mathrm{O} \mathrm{pH}$ da solução foi ajustado em 8 com solução de $\mathrm{KOH} 2 \mathrm{M}$ e o meio foi autoclavado $\left(12{ }^{\circ} \mathrm{C}\right.$, 20 minutos).

Meio sólido de extrato de malte 2\% (MA2): em um frasco tipo shott foram adicionados extrato de malte (30 g), peptona de farinha de soja (3 g), agar (15 g) e água do mar artificial $(1 \mathrm{~L}) . \mathrm{O}$ pH do meio foi ajustado em 8 com solução de $\mathrm{KOH} 2 \mathrm{M}$ e o meio foi autoclavado $\left(120^{\circ} \mathrm{C}, 20\right.$ minutos $)$.

Meio sólido nutrient broth (NB): em um frasco tipo shott foram adicionados extrato nutrient broth (3 g), peptona de farinha de soja (5 g), agar (15 g) e água do mar artificial (100 mL). O pH do meio foi ajustado em 8 com solução de KOH 2M e o meio foi autoclavado $\left(120^{\circ} \mathrm{C}, 20\right.$ minutos $)$.

Todos os micro-organismos foram cultivados em meio líquido de extrato de malte $2 \%$, os quais foram utilizados para realizar as reações de redução de cetonas. $\mathrm{O}$ meio sólido NB foi somente utilizado para cultivar as bactérias Br-01 e Bt-01 para identificação.

Água do mar artificial

Composição da água do mar artificial (1L): $\mathrm{CaCl}_{2} \cdot 2 \mathrm{H}_{2} \mathrm{O}(1,26 \mathrm{~g}), \mathrm{MgCl}_{2} \cdot 6 \mathrm{H}_{2} \mathrm{O}$ $(9,68 \mathrm{~g}), \mathrm{KCl}(0,61 \mathrm{~g}), \mathrm{NaCl}(30,0 \mathrm{~g}), \mathrm{Na}_{2} \mathrm{HPO}_{4}(0,014 \mathrm{mg}), \mathrm{Na}_{2} \mathrm{SO}_{4}(3,47 \mathrm{~g}), \mathrm{NaHCO}_{3}$ $(0,17 \mathrm{~g}), \mathrm{KBr}(0,1 \mathrm{~g}), \mathrm{SrCl}_{2} \cdot 6 \mathrm{H}_{2} \mathrm{O}(0,040 \mathrm{~g}), \mathrm{H}_{3} \mathrm{BO}_{3}(0,030 \mathrm{~g})$. 
Reações de biocatálise com algas $B$. tenella e B. radicans

As algas foram descongeladas em refrigerador sob temperatura de $4{ }^{\circ} \mathrm{C}$, mantendo embaladas e imersas em água destilada. Em seguida foram lavadas em água do mar artificial (pH 8) e imersas por $30 \mathrm{~s}$ em solução de hipoclorito de sódio 0,01\% e por último lavadas com água destilada. Em frascos erlenmeyers de $250 \mathrm{~mL}$ foi adicionada água destilada $(100 \mathrm{~mL})$, as algas $(5 \mathrm{~g})$ e as cetonas $(10-50 \mathrm{mg})$ dissolvidas em $300 \mu \mathrm{L}$ de DMSO. As reações foram mantidas sob agitação orbital (150 rpm, 32 $\left.{ }^{\circ} \mathrm{C}\right)$. Alíquotas foram retiradas em tempos fixados e analisadas por cromatografia gasosa utilizando-se coluna quiral de ciclodextrina.

Reações de biocatálise com as bactérias e fungos isolados das algas (B. tenella, B. radicans e Sargassum sp) e com os fungos marinhos

Em frascos erlenmeyers de $250 \mathrm{~mL}$ foi adicionado o meio de cultura de extrato de malte 2\% (100 mL). Cultivaram-se as bactérias (Bt-01, Bt-02), os fungos (SMA2-C, SMA2-8, SMA2-58, SGPY-41, F-09, F-23, F-27, F-61) por 2-3 dias em agitação orbital $\left(150 \mathrm{rpm}, 32^{\circ} \mathrm{C}\right)$. Após este tempo adicionou-se ao meio de cultivo as cetonas $(10-50$ mg) dissolvidas em $300 \mu \mathrm{L}$ de DMSO. As reações foram mantidas sob agitação (150 rpm, $32{ }^{\circ} \mathrm{C}$ ). Alíquotas foram retiradas em tempos fixados e analisadas por cromatografia gasosa utilizando-se coluna quiral de ciclodextrina.

O mesmo procedimento foi realizado para os fungos marinhos, (Aspergillus sydowii Ce15, Aspergillus sydowii Ce19, Aspergillus sydowii Gc12, Bionectria sp Ce5, Penicillium raistrickii Ce16, Penicillium miczynskii Gc5 e o Trichoderma sp Gc1), porém estes foram cultivados por 5 dias. 
Após as reações serem completadas, foi realizada uma filtração a vácuo (fungos) em capela de fluxo laminar e os produtos obtidos das reações biocatalisadas foram extraídos com acetato de etila $(3 \times 30 \mathrm{~mL})$ em funil de separação. À fase orgânica adicionou-se sulfato de sódio anidro, filtrou-se e evaporou-se o solvente sob pressão reduzida. O rendimento foi obtido após purificação por cromatografia em coluna utilizando sílica gel como fase estacionária e hexano /acetato de etila como eluentes. Os rendimentos para algumas reações estão sumarizados na tabela 1.

Tabela 1. Rendimento das reações biorredução

\begin{tabular}{lccc}
\hline \multicolumn{1}{c}{ Biocatalisador } & $\mathrm{t}($ dias $)$ & Cetona & Álcool $(\%)$ \\
\hline alga B. radicans & 7 & $\mathbf{1}(50 \mathrm{mg} ; 0,20 \mathrm{mmol})$ & 15 \\
bactéria Bt-01 & 8 & $\mathbf{1}(50 \mathrm{mg} ; 0,20 \mathrm{mmol})$ & 20 \\
fungo SMA2-09 & 10 & $\mathbf{1}(50 \mathrm{mg} ; 0,20 \mathrm{mmol})$ & 32 \\
fungo SMA2-61 & 10 & $\mathbf{1}(50 \mathrm{mg} ; 0,20 \mathrm{mmol})$ & 40 \\
bactéria Bt-01 & 8 & $\mathbf{2}(50 \mathrm{mg} ; 0,20 \mathrm{mmol})$ & 19 \\
alga B. tenella & 8 & $\mathbf{3}(50 \mathrm{mg} ; 0,20 \mathrm{mmol})$ & 15 \\
fungo SAM2-C & 10 & $\mathbf{7}(50 \mathrm{mg} ; 0,36 \mathrm{mmol})$ & 34 \\
fungo SAM2-09 & 10 & $\mathbf{8}(50 \mathrm{mg} ; 0,32 \mathrm{mmol})$ & 50 \\
fungo SMA2-61 & 10 & $\mathbf{8}(50 \mathrm{mg} ; 0,32 \mathrm{mmol})$ & 55 \\
fungo SMA2-58 & 10 & $\mathbf{8}(50 \mathrm{mg} ; 0,32 \mathrm{mmol})$ & 44 \\
bactéria Bt-01 & 10 & $\mathbf{9}(50 \mathrm{mg} ; 0,25 \mathrm{mmol})$ & 15 \\
fungo SAM2-09 & 10 & $\mathbf{9}(50 \mathrm{mg} ; 0,25 \mathrm{mmol})$ & 54 \\
bactéria Bt-01 & 10 & $\mathbf{1 0}(50 \mathrm{mg} ; 0,30 \mathrm{mmol})$ & 23 \\
fungo SAM2-09 & 10 & $\mathbf{1 0}(50 \mathrm{mg} ; 0,30 \mathrm{mmol})$ & 40 \\
fungo SMA2-61 & 10 & $\mathbf{1 0}(50 \mathrm{mg} ; 0,30 \mathrm{mmol})$ & 46 \\
fungo Gc12 & 7 & $\mathbf{1 5}(50 \mathrm{mg} ; 0,24 \mathrm{mmol})$ & 60 \\
fungo Gc1 & 7 & $\mathbf{1 6}(50 \mathrm{mg} ; 0,18 \mathrm{mmol})$ & 30 \\
\hline
\end{tabular}


As cromatografias em coluna (CC) foram realizadas utilizando-se sílica gel 60 230-400 flesh da Across e cromatofolhas de sílica gel $60 \mathrm{~F}_{254}$ da Sorbent Technologies para cromatografia em camada delgada (CCD). As cromatofolhas foram analisadas em uma câmara com luz UV (254 nm) e reveladas com de solução de anisaldeído (100 mL de ácido acético, $1 \mathrm{~mL}$ de $p$-anisaldeído, $1 \mathrm{~mL}$ de ácido sulfúrico) ou com solução alcoólica de vanilina ( $135 \mathrm{~mL}$ de $\mathrm{H}_{2} \mathrm{O}$ destilada, $30 \mathrm{~mL}$ de ácido sulfúrico, $35 \mathrm{~mL}$ de metanol, $3 \mathrm{~g}$ de vanilina). Como fase móvel, utilizou-se misturas de solventes (hexano e acetato de etila).

\section{Evaporadores rotativos}

Para remoção dos solventes foram utilizados rotaevaporadores da marcas Fisaton e Tecnal T-210, equipados com bomba de vácuo TE-058 e refrigeração Tecnal modelo TE-2005.

\section{Agitador orbital rotativo termostatizado}

O crescimento dos fungos e as reações de biorredução de cetonas foram realizadas em agitador rotativo modelo Tecnal TE-421 ou Superhom.

\section{Outros equipamentos}

Balança analítica modelo AY-220 marca Shimadzu, capela de fluxo laminar marca Veco, autoclave vertical modelo Phoenix, pHmetro modelo 8010 da marca Qualxtron. 
As medidas de rotação óptica foram realizadas no Departamento de QuímicaUFSCar em um Polarímetro Perkin-Elmer modelo 241 (Walthan MA, USA) equipado com lâmpada de $\mathrm{Na}(\lambda 589 \mathrm{~nm})$. As amostras foram diluídas em $1 \mathrm{~mL}$ de $\mathrm{CHCl}_{3}$ grau HPLC e os experimentos foram realizados a $25{ }^{\circ} \mathrm{C}$. Os dados de rotação óptica estão sumarizados na tabela 2. Todos os alcoóis tiveram sua configuração absoluta determinada, exceto para o 4,4,4-triflúor-1-(naftalen-2-il)-3-hidroxibutan-1-ol (18).

Tabela 2. Dados de rotação óptica e tempo de retenção dos enantiômeros dos alcoóis em coluna quiral CP-Chirasil-Dex-CB-Varian (25 m x 0,25 mm x 0,39 $\mu \mathrm{m})$

\begin{tabular}{|c|c|c|c|c|}
\hline Composto & {$[\alpha]_{D}^{25} \exp$} & {$[\alpha]_{D}^{25}$ lit. } & $\mathrm{t}_{\mathrm{r}}(\min )$ & Ref. \\
\hline \multirow[t]{2}{*}{ 1-(2-iodofenil)etanol (4) } & $(S)-17,6^{\circ}$ & $(R)+37,7^{\circ}$ & (R) 18,0 & [a] \\
\hline & $\left(c 1,7 ; \mathrm{CHCl}_{3}\right)$ & $\left(c 0,934 ; \mathrm{CHCl}_{3}\right)$ & (S) 20,0 & \\
\hline \multirow[t]{2}{*}{ 1-(3-iodofenil)etanol (5) } & $\mathrm{Ca}$ & $(S)-12,9^{\circ}$ & $(R) 21,0$ & [b] \\
\hline & & $\left(\right.$ c 2,$\left.4 ; \mathrm{CHCl}_{3}\right)$ & (S) 22,5 & \\
\hline \multirow[t]{2}{*}{ 1-(4-iodofenil)etanol (6) } & $\mathrm{Ca}$ & $(S)-32,7^{\circ}$ & (R) 20,0 & [c] \\
\hline & & $\left(\right.$ c 5,$\left.99 ; \mathrm{CHCl}_{3}\right)$ & (S) 22,5 & \\
\hline \multirow{2}{*}{$\begin{array}{l}\text { 1-(2-fluorofenil)etanol } \\
\text { (11) }\end{array}$} & $(S)-45,5^{\circ}$ & $(S)-43,5^{\circ}$ & (R) 21,1 & [d] \\
\hline & $\left(c 2,0 ; \mathrm{CHCl}_{3}\right)$ & $\left(c 1,39 ; \mathrm{CHCl}_{3}\right)$ & (S) 22,5 & \\
\hline \multirow{2}{*}{$\begin{array}{l}\text { 1-(2-clorofenil)etanol } \\
\text { (12) }\end{array}$} & $\mathrm{Ca}$ & $(S)-57,7^{\circ}$ & (R) 23,0 & [d] \\
\hline & & $\left(c 1,46 ; \mathrm{CHCl}_{3}\right)$ & (S) 25,0 & \\
\hline \multirow{2}{*}{$\begin{array}{l}\text { 1-(2-bromofenil)etanol } \\
\text { (13) }\end{array}$} & $(R)+26^{\circ}$ & $(S)-50,45^{\circ}$ & (R) 24,0 & [d] \\
\hline & $\left(c 2,5 ; \mathrm{CHCl}_{3}\right)$ & $\left(c 1,33 ; \mathrm{CHCl}_{3}\right)$ & (S) 26,0 & \\
\hline \multirow{2}{*}{$\begin{array}{l}\text { 1-(2-nitrofenil)etanol } \\
\text { (14) }\end{array}$} & $(S)+17^{\circ}$ & $(S)+18,5^{\circ}$ & (R) 26,0 & [e] \\
\hline & $\left(c 1,8 ; \mathrm{CHCl}_{3}\right)$ & $(c 0,23 ; \mathrm{MeOH})$ & (S) 27,5 & \\
\hline \multirow{3}{*}{$\begin{array}{l}\text { 4,4,4-triflúor-1-(furan-2- } \\
\text { il)-3-hidroxibutan-1-ol } \\
\text { (17) }\end{array}$} & $(R)+10,6^{\circ}$ & $(R)+18,3^{\circ}$ & (S) 17,5 & [f] \\
\hline & $\left(c 1,6 ; \mathrm{CHCl}_{3}\right)$ & $\left(\mathrm{CHCl}_{3}\right)$ & (R) 18,3 & \\
\hline & & & & \\
\hline \multirow{3}{*}{$\begin{array}{l}\text { 4,4,4-triflúor-1- } \\
\text { (naftalen-2-il)-3- } \\
\text { hidroxibutan-1-ol (18) }\end{array}$} & $-6^{\circ} \quad(c$ & $\mathrm{Nd}[\mathrm{g}]$ & 19,3 & \\
\hline & $\left.\mathrm{CHCl}_{3}\right)$ & & 20,0 & \\
\hline & & & & \\
\hline
\end{tabular}

[a] Izumi, T.; Itou, O.; Kodera, K. J. Chem. Tech. Biotechnol. 1996, 67, 89 
[b] Da Rocha, L.C. Redução de derivados de acetofenonas com fungos de origem marinha. Dissertação de mestrado. IQSC, USP, 2008.

[c] Salvi, N.A.; Chattopadhyay, S. Tetrahedron 2001, 57, 2833

[d] Salvi, N.A.; Chattopadhyay, S. Tetrahedron: Asymmetry 2008, 19, 1992

[e] Barros-Filho, B.A.; De Oliveira, M.C.F.; Lemos, T.L.G.; De Mattos, M.C.; De Gonzalo, G.; GotorFernández, V.; Gotor, V. Tetrahedron: Asymmetry 2009, 20, 1057

[f] Forni, A.; Moretti, I.; Prati, F.; Torre, G. Tetrahedron 1994, 50, 11995

$[\mathrm{g}] \mathrm{Nd}=$ Não determinado

$\mathrm{Ca}=$ configuração absoluta determinada pelo tempo de retenção de cada enantiômero

exp. = dado de rotação óptica experimental; lit. = dado de rotação óptica experimental; $\mathrm{t}_{\mathrm{r}}=$ tempo de retenção em coluna quiral para cada enantiômero

Cromatografia a gás

Todas as reações de biocatálise foram analisadas por cromatografia gasosa utilizando coluna quiral com fase estacionária CP-Chirasil-Dex-CB-Varian Capillary Column com EZ-GRIP ${ }^{\mathrm{TM}}(25 \mathrm{~m}$ x 0,25 mm x 0,39 $\mu \mathrm{m})$. O gás de arraste foi nitrogênio. O equipamento utilizado foi um cromatógrafo a gás da Marca Shimadzu, Modelo GC2010 com auto-injetor AOC-20i. Na tabela 3 têm-se os dados da programação utilizadas no cromatógrafo a gás com coluna quiral de ciclodextrina. 
Tabela 3. Programação utilizada no CG para as análises das reações

\begin{tabular}{|c|c|c|c|c|c|c|}
\hline Composto & $\mathrm{T}_{\mathrm{i}}$ & $\mathrm{t}_{\mathrm{i}}$ & $T_{f}$ & $t_{f}$ & $\mathrm{r}$ & $\mathrm{t}_{\mathrm{r}}$ \\
\hline 1 & 115 & 2 & 175 & 8 & 3 & 11,0 \\
\hline 4 & 115 & 2 & 175 & 8 & 3 & 18,0 e 20,0 \\
\hline 2 & 120 & 2 & 190 & 8 & 3 & 11,3 \\
\hline 5 & 120 & 2 & 190 & 8 & 2 & 21,0 e 22,5 \\
\hline 3 & 120 & 2 & 165 & 8 & 2 & 11,5 \\
\hline 6 & 120 & 2 & 165 & 8 & 2 & 21,0 e 22,0 \\
\hline 7 & 100 & 2 & 180 & 5 & 2 & 7,5 \\
\hline 11 & 100 & 2 & 180 & 5 & 2 & 21,0 e 22,0 \\
\hline 8 & 100 & 2 & 180 & 5 & 2 & 11,5 \\
\hline 12 & 60 & 2 & 180 & 5 & 2 & 23,0 e 25,0 \\
\hline 9 & 90 & 2 & 140 & 6 & 2 & 10,5 \\
\hline 13 & 90 & 2 & 140 & 6 & 2 & 24,0 e 26,0 \\
\hline 10 & 100 & 2 & 150 & 6 & 2 & 16,0 \\
\hline 14 & 100 & 2 & 150 & 6 & 2 & 26,0 e 27,0 \\
\hline 15 & 110 & 2 & 180 & 6 & 2 & 13,0 \\
\hline 17 & 110 & 2 & 180 & 6 & 2 & 17,5 e 183 \\
\hline 16 & 120 & 2 & 180 & 6 & 2 & 16,0 \\
\hline 18 & 120 & 2 & 180 & 6 & 2 & 19,0 e 20,0 \\
\hline
\end{tabular}

$\mathrm{T}_{\mathrm{i}}\left({ }^{\circ} \mathrm{C}\right)=$ temperatura inicial; $\mathrm{T}_{\mathrm{f}}\left({ }^{\circ} \mathrm{C}\right)=$ Temperatura final; $\mathrm{t}_{\mathrm{i}}(\min )=$. tempo inicial; $\mathrm{t}_{\mathrm{f}}(\min )=$. tempo final; $r\left({ }^{\circ} \mathrm{C} / \mathrm{min}.\right)=$ taxa de aquecimento; $\mathrm{t}_{\mathrm{r}}(\mathrm{min}$.) tempo de retenção 
Biocatalisadores de origem marinha (algas, bactérias e fungos) para redução estereosseletiva de cetonas

\title{
RESULTADOS E DISCUSSÕES
}

\author{
Ana Maria Mouad
}

Prof. Dr. André L.M. Porto 


\section{ISOLAMENTO DE MICRO-ORGANISMOS ASSOCIADOS ÀS ALGAS Bostrychia tenella e Bostrychia radicans}

As algas Bostrychia tenella e Bostrychia radicans coletadas mantidas no laboratório, foram descongeladas e lavadas com água do mar artificial, filtradas em peneira, sendo em seguida imersas em solução de hipoclorito de sódio 0,01\% por $30 \mathrm{~s}$. Após as lavagens, as algas (5 g) foram transferidas para frascos erlenmeyers de $250 \mathrm{~mL}$ contendo água esterilizada $(100 \mathrm{~mL})$. Os frascos foram levados para um agitador orbital por 5 dias $\left(150 \mathrm{rpm}, 32{ }^{\circ} \mathrm{C}\right)$. Após este período de incubação, retirou-se com auxílio de um alça de inoculação amostras do caldo, transferindo-as para placas de Petri contendo o meio de cultura de extrato de malte $2 \%$.

Neste isolamento optou-se pelo uso do meio de cultura de extrato de malte $2 \%$ para selecionar preferencialmente o crescimento de fungos. Após os inóculos, as placas foram incubadas em estufa $\left(30^{\circ} \mathrm{C}\right)$ por até 8 dias, onde obteve-se um crescimento microbiano uniforme. Contudo, as colônias que se desenvolveram no extrato de malte foram de bactérias filamentosas. Assim, realizou-se o cultivo destes isolados em meio de cultura de ágar nutriente (Nutrient Broth). As colônias destes microrganismos isolados também cresceram de forma uniforme e com filamentos. Amostras destes foram enviadas para identificação no Centro de Pesquisas Químicas Biológicas e Agrícolas (CPQBA/UNICAMP) sob responsabilidade da Dra. Fabiana FantinattiGarboggini.

As bactérias isoladas (Malte 2\%) foram submetidas às reações de biocatálise para avaliar a presença de enzimas álcool desidrogenases utilizando-se cetonas como substratos. 
Na figura 1 têm-se as algas Bostrychia radicans e tenella suspensas em água esterilizada. Na figura 2 têm-se colônias das bactérias isolados das algas marinhas $B$. tenella (Bt-01) e B. radicans (Br-01) em meio de cultura NB.
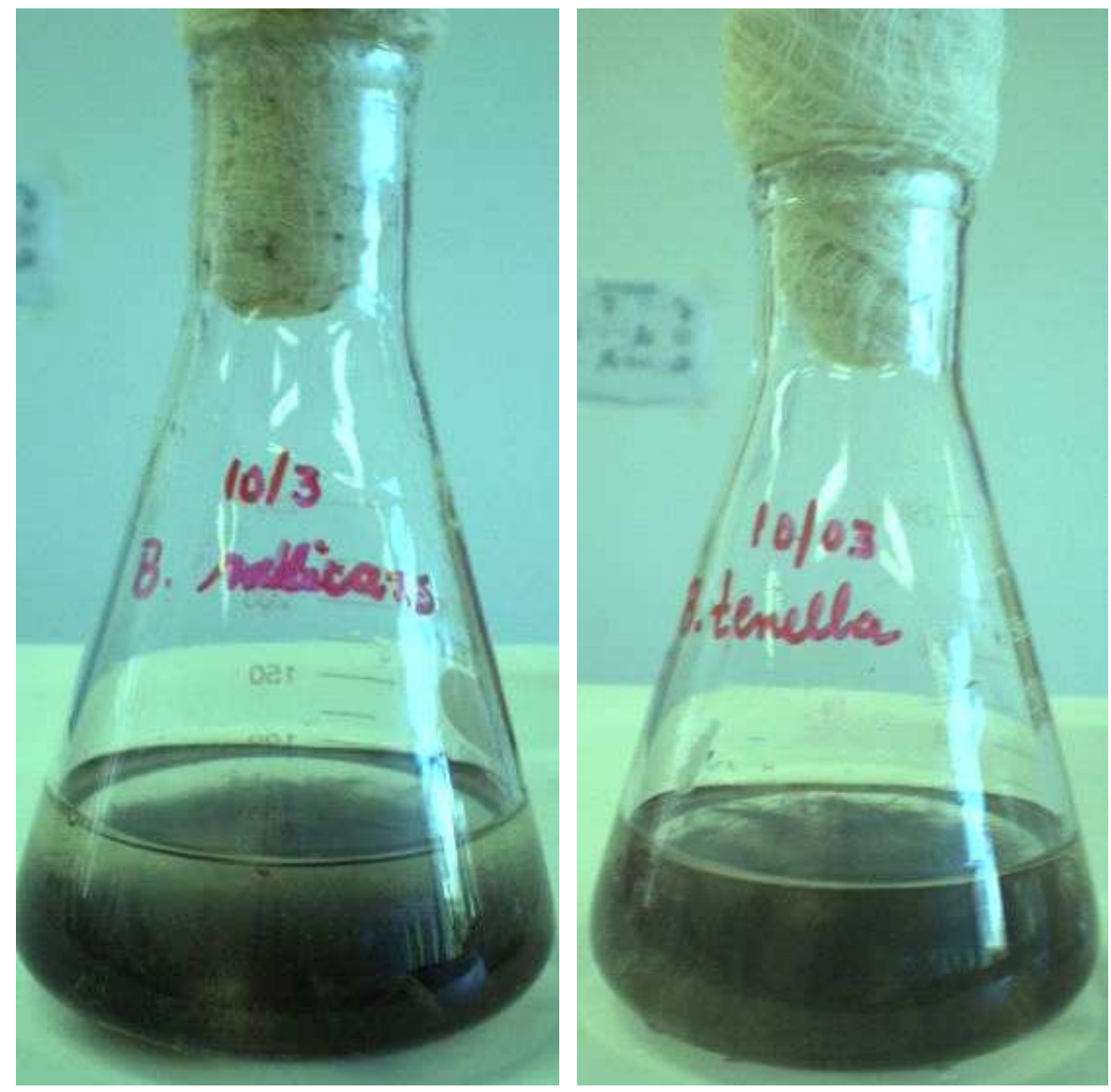

Figura 1. Algas Bostrychia radicans e B. tenella suspensas em água esterilizada.
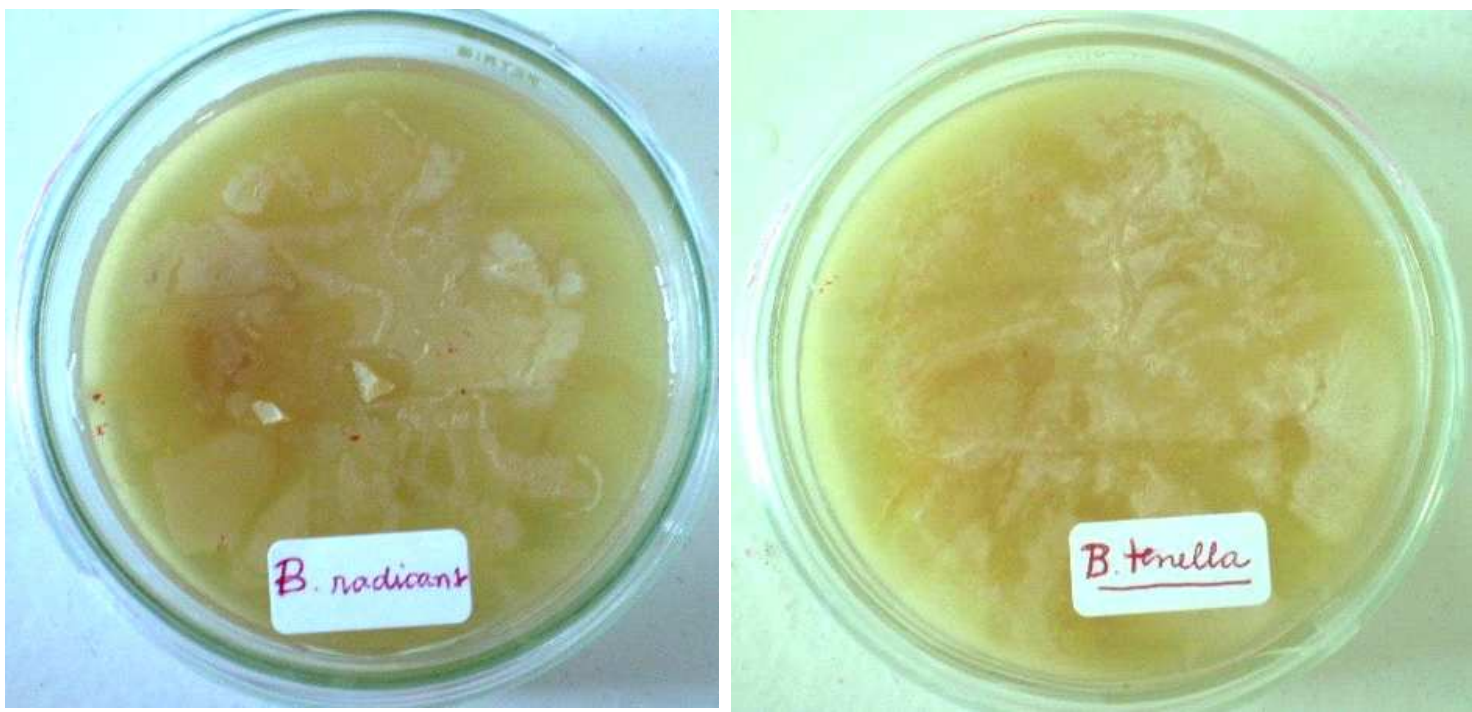

Figura 2. Bactérias isoladas das algas marinhas B. radicans (Br-01) e B. tenella (Bt-01) em meio de cultura NB (nutrient broth) 
Pelo grupo da Profa. Dra. Hosana M. Debonsi foram realizados isolamentos de fungos presentes na alga $B$. radicans. A alga B. radicans após esterilização foi cortada em pequenos fragmentos os quais foram transferidos assepticamente para placas de Petri contendo meio de cultura apropriado. Após a incubação da placa em estufa a $28{ }^{\circ} \mathrm{C}$ por até 8 dias obteve-se o crescimento de várias colônias de microrganismos. A partir de sucessivos repiques chegou-se a obtenção de colônias puras. Os fungos isolados (Br-09, Br-23, Br-27 e Br-62) em meio de cultura de batata foram mantidos no laboratório e utilizados para as reações de biocatálise em meio de extrato de malte $2 \%$.

Na figura 3, têm-se o crescimento de colônias de fungos oriundos da alga $B$. radicans. Na figura 4, têm-se os fungos isolados de B. radicans, os quais foram obtidos por novos repiques realizados no laboratório de Biocatálise /IQSC, para este trabalho, e que foram utilizados como fontes biocatalíticas em reações de redução de cetonas.

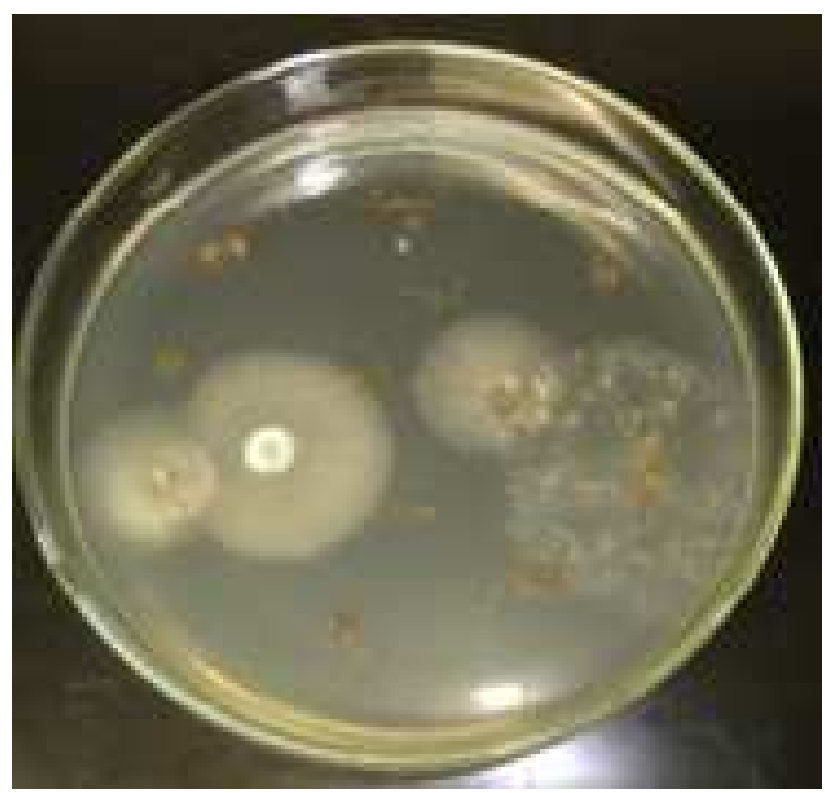

Figura 3. Colônias de microrganismos obtidas da alga Bostrychia radicans em meio de batata 


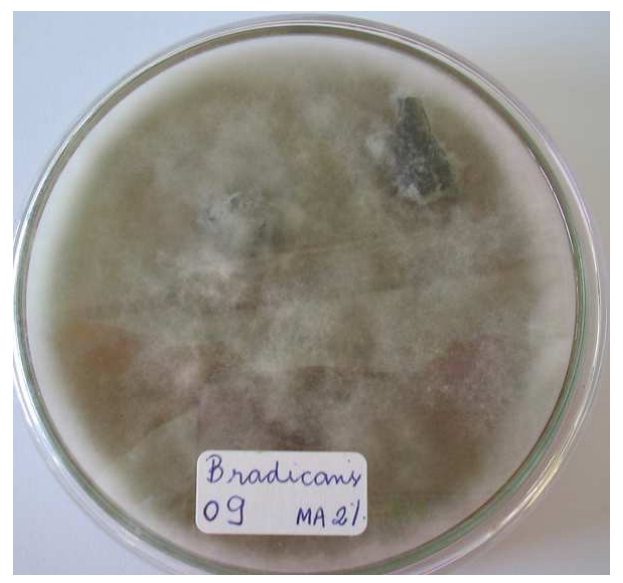

Linhagem Br-09

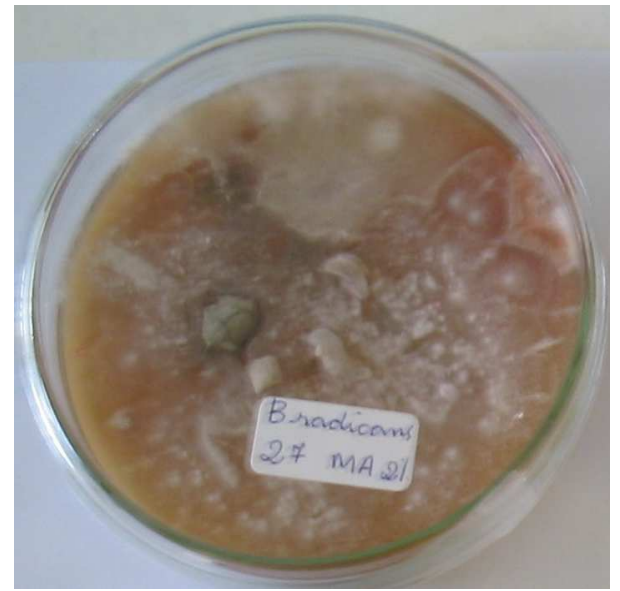

Linhagem Br-27

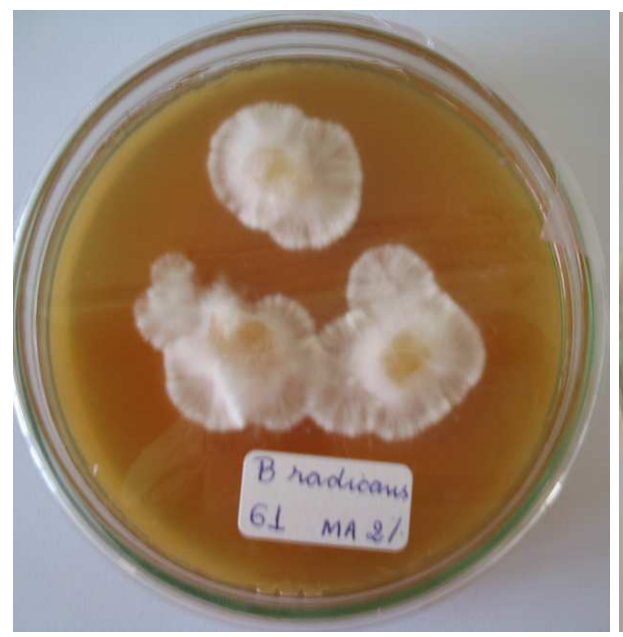

Linhagem Br-61

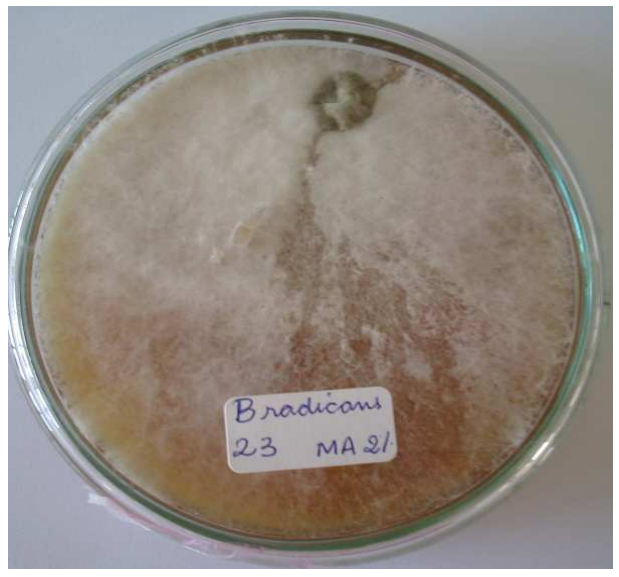

Linhagem Br-23

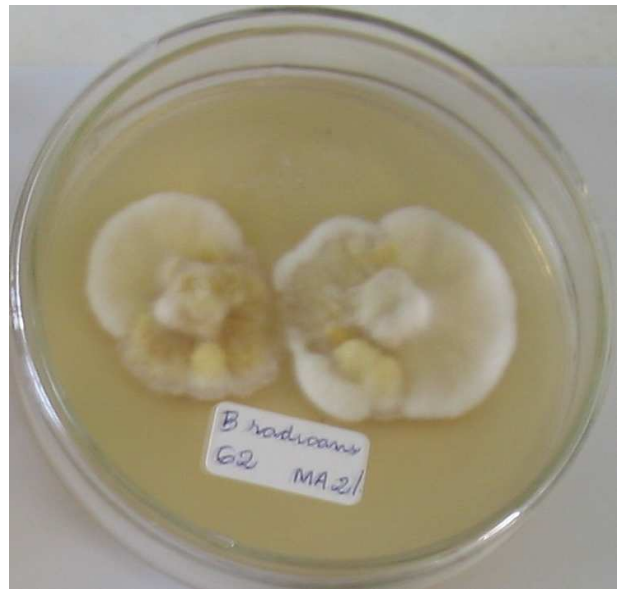

Linhagem $\mathrm{Br}-62 *$

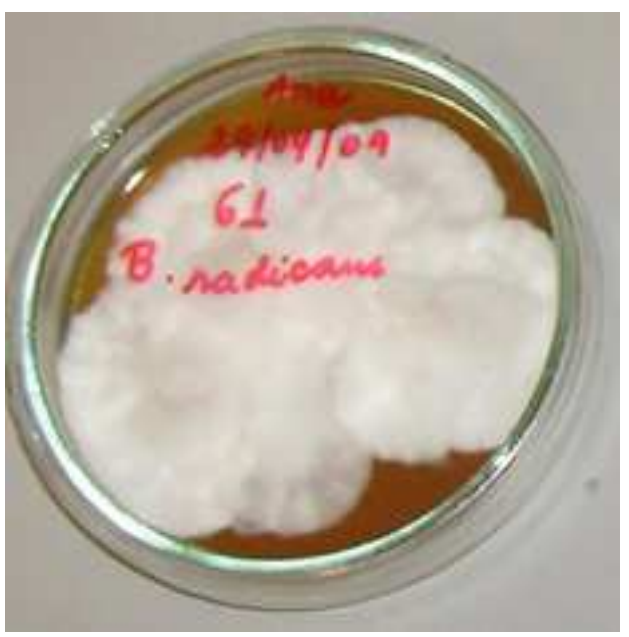

Linhagem Br-61

Figura 4. Fungos isolados da alga Bostrychia radicans e cultivados em meio de cultura de extrato de malte. *linhagem Br-62 não utilizada nas reações de biocatálise 


\section{REDUÇÃO DE IODOACETOFENONAS COM A ALGA MARINHA Bostrychia tenella}

As primeiras reações de redução com a alga marinha Bostrychia tenella foram realizadas com as iodoacetofenonas $\mathbf{1}$ - $\mathbf{3}$.

Nestes ensaios foram realizados 5 experimentos, variando-se a concentração de iodoacetofenonas 1 - 3 adicionadas: $10 \mathrm{mg}(0,041 \mathrm{mmol}) ; 20 \mathrm{mg}(0,082 \mathrm{mmol}) ; 30 \mathrm{mg}$ $(0,12 \mathrm{~mol}) ; 40 \mathrm{mg}(0,16 \mathrm{mmol}) ; 50 \mathrm{mg}(0,20 \mathrm{mmol})$.

Após o preparo das reações, os frascos foram levados ao agitador rotativo (150 $\mathrm{rpm}, 32^{\circ} \mathrm{C}$ ) e as reações foram mantidas sob agitação em tempos fixados. Amostras das reações foram retiradas com pipetas de Pasteur, filtradas e extraídas com acetato de etila e analisadas por cromatografia gasosa utilizando-se coluna capilar com fase estacionária quiral de ciclodextrina. Os resultados das reações com a alga B. tenella encontram-se sumarizados na tabela 1 . 
Tabela 1. Redução de iodoacetofenonas 1 - 3 com a alga marinha Bostrychia tenella

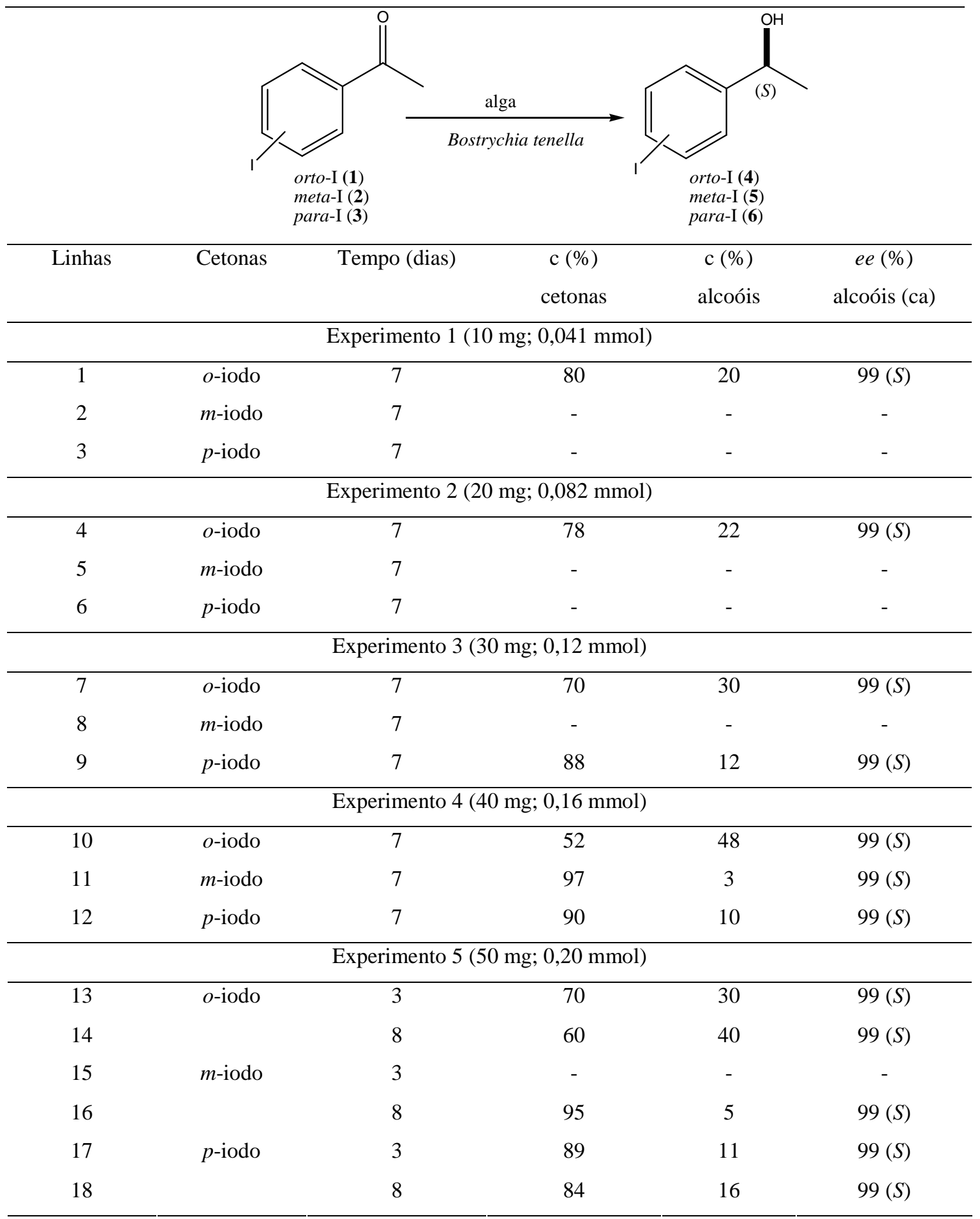

Condições reacionais: em frascos erlenmeyers de $250 \mathrm{~mL}$ foram adicionados água esterilizada (100 mL), alga $B$. tenella $(5 \mathrm{~g})$, iodoacetofenonas 1 - $3(10-50 \mathrm{mg})$ dissolvidas em $300 \mu \mathrm{L}$ de DMSO. As reações foram mantidas sob agitação orbital $\left(150 \mathrm{rpm}, 32{ }^{\circ} \mathrm{C}\right)$. Alíquotas foram retiradas em tempos fixados e analisadas por cromatografia gasosa utilizando-se coluna quiral de ciclodextrina. c (\%): concentração determinada por $\mathrm{CG}$; ee $(\%)$ : excesso enantiomérico; ca: configuração absoluta. 
Pelos dados obtidos na tabela 1 pode-se observar que as iodoacetofenonas 1 e 3 foram reduzidas nos respectivos alcoóis em até 8 dias de reação. Em todos os casos os alcoóis 4 - 6 apresentaram excelentes seletividades, pois os excessos enantioméricos foram superiores a 98\%. Observou-se que a $o$-iodoacetofenona 1 apresentou melhores resultados, pois em 8 dias de reação obteve-se $48 \%$ da cetona remanescente (Linha 14, Tabela 1). Constatou-se que as conversões da $o$-iodoacetofenona 1 foram dependentes da quantidade de cetona adicionada, pois a concentração do álcool $(S)-\mathbf{4}$ formado aumentou de 20 para 52\% (concentrações de 0,041 mmol a 0,20 mmol). (Linhas 1, 4, 7, 10 e 14, Tabela 1).

A $m$-iodoacetofenona 2 teve uma discreta redução, obtendo-se entre 3 - 5\% do álcool $(S)$-5, mesmo prolongando-se o tempo reacional por 8 dias (Linhas 11 e 16, Tabela 1). Inclusive em quantidades inferiores adicionadas $(10-30 \mathrm{mg})$ de cetona 2 não se observou a formação do álcool $\mathbf{5}$.

O mesmo ocorreu para a $p$-iodoacetofenona $\mathbf{3}$, ou seja, em menores quantidades de cetona adicionada, não foram observadas conversões. Enquanto que em concentrações superiores obteve-se uma maior conversão, porém não ultrapassando 13\% (Linhas 9, 12 e 18, Tabela 1).

Os alcoóis 4 - 6 foram obtidos com seletividade Prelog, pois apresentaram configurações absolutas $S$. A configuração absoluta foi determinada pela medida da rotação óptica e comparada com a literatura (Parte II, Materiais e Métodos).

Concluiu-se através destes experimentos que a alga marinha Bostrychia tenella tem potencial para redução das iodoacetofenonas $\mathbf{1}-\mathbf{3}$, pois os álcoois apresentaram excelentes excessos enantioméricos. Como estas reações envolvem a redução de grupos proquirais, a seletividade das reações independe da conversão. Portanto, as enzimas 
presentes na alga $B$. tenella apresentam excelentes seletividades para estas reações de redução.

Nas figuras 5 - 7 têm-se os cromatogramas dos padrões das iodoacetofenonas 1 . 3 e dos álcoois racêmicos 4 - $\mathbf{6}$ obtidos por cromatografia gasosa em coluna quiral de ciclodextrina.
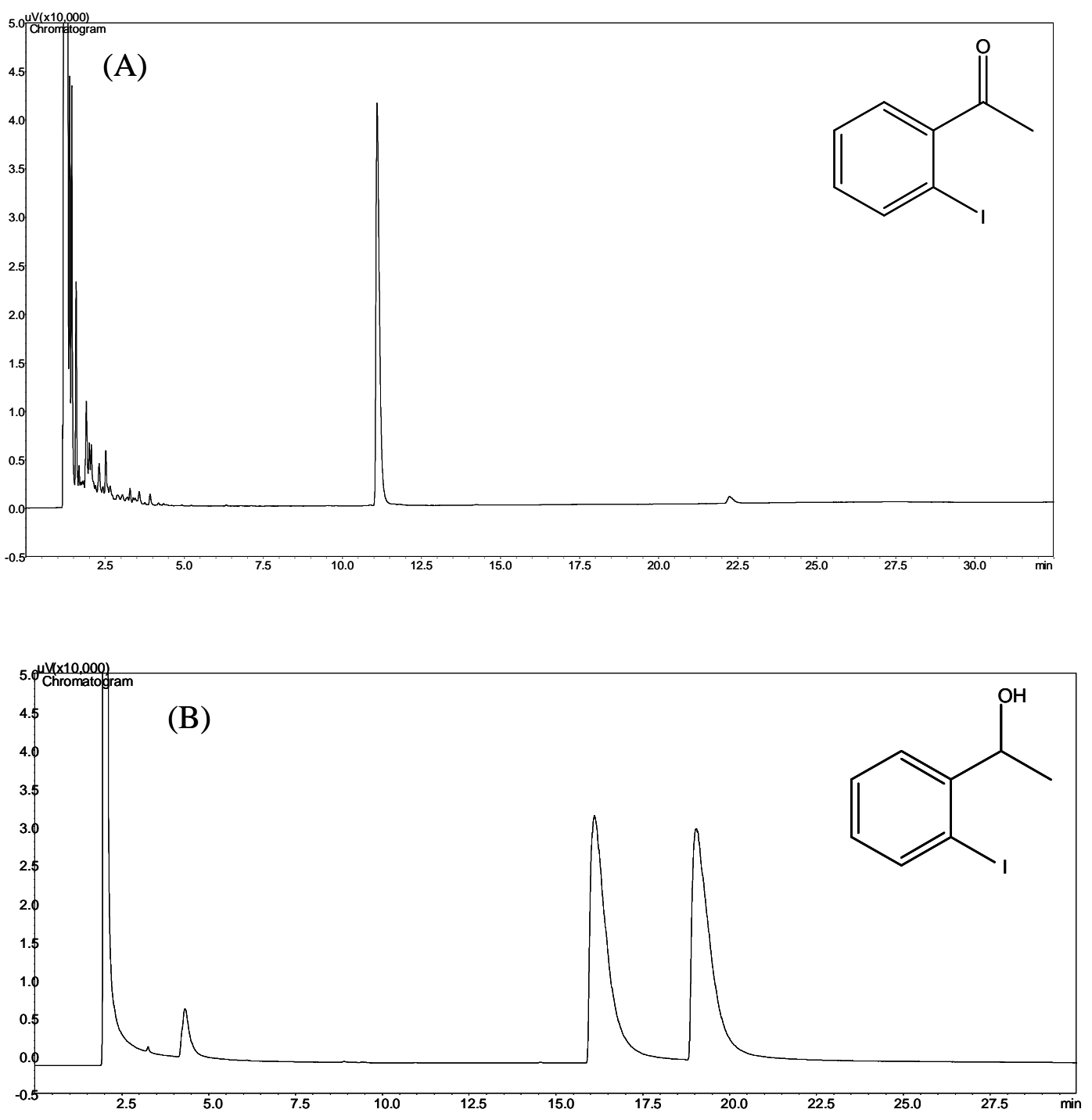

Figura 5. Cromatogramas obtidos por CG. (A) padrão da $o$-iodoacetofenona 1

(B) padrão do 1-(2-iodofenil)etanol rac-4 

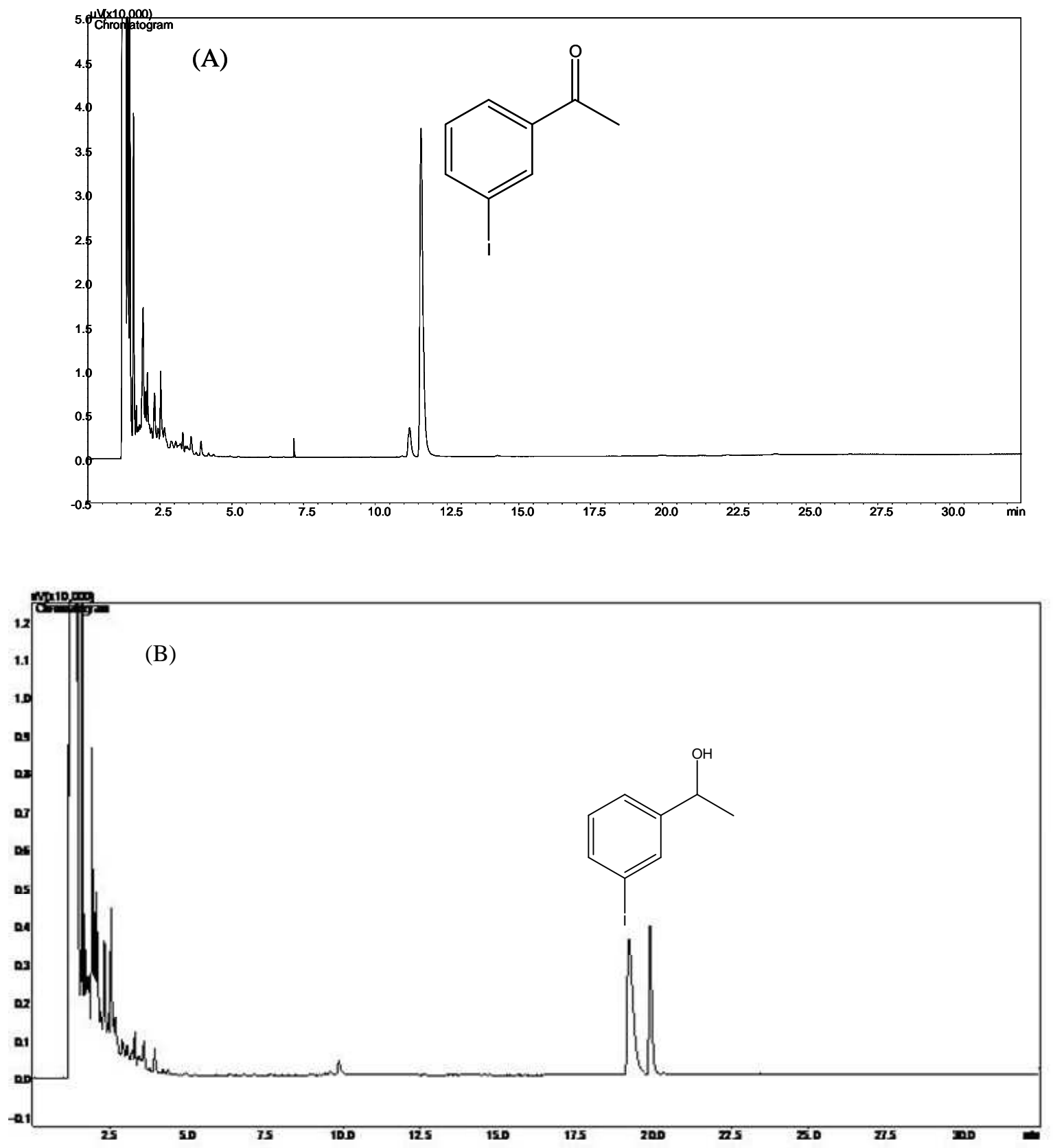

Figura 6. Cromatogramas obtidos por $\mathrm{CG}$. (A) padrão da $m$-iodoacetofenona 2 (B) padrão do 1-(3-iodofenil)etanol rac-5 

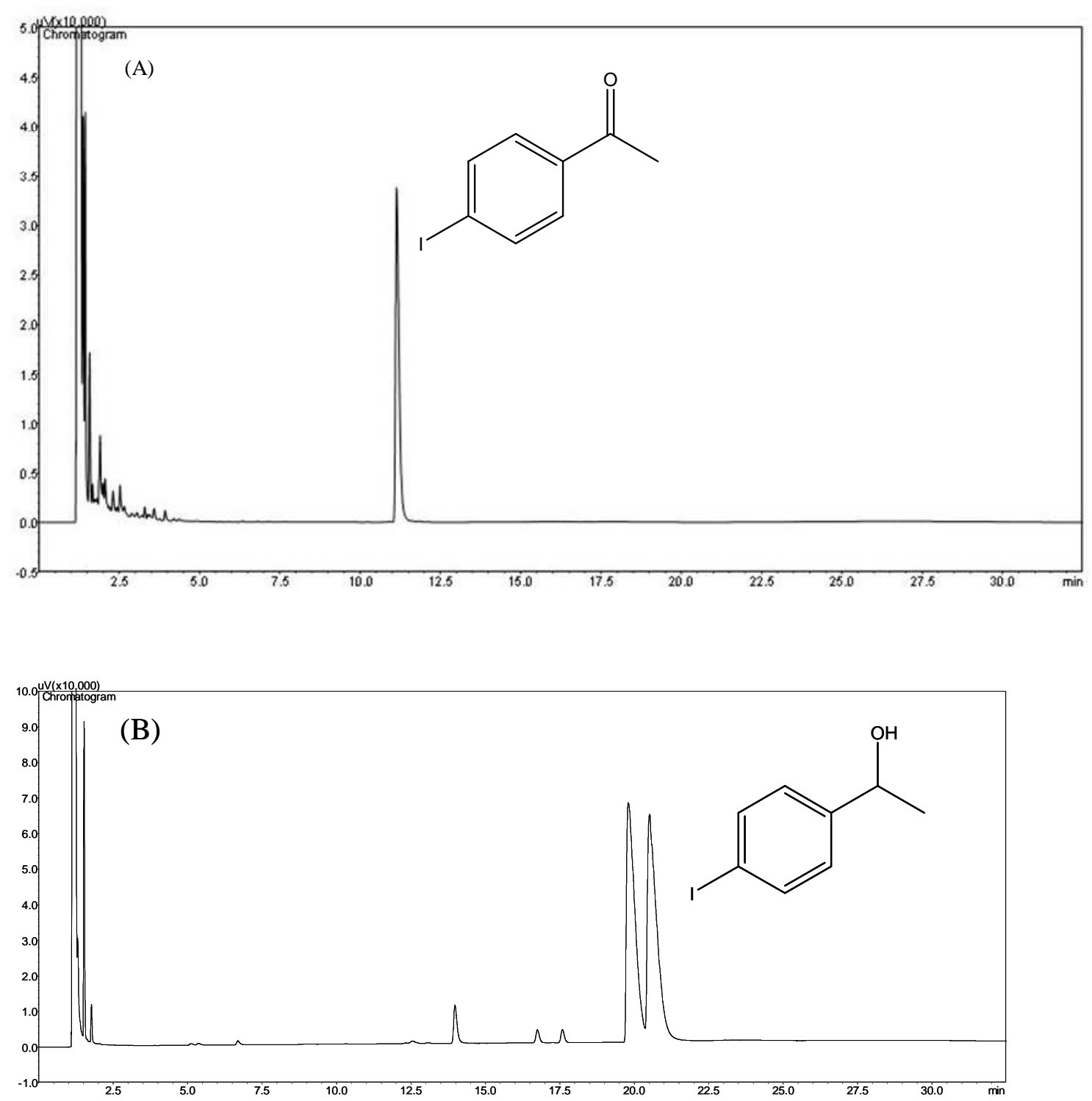

Figura 7. Cromatogramas obtidos por CG. (A) padrão da $p$-iodoacetofenona 3 (B) padrão do 1-(2-iodofenil)etanol rac-6 


\section{REDUÇÃO DE IODOACETOFENONAS COM A ALGA MARINHA}

\section{Bostrychia radicans}

Dando continuidade aos experimentos, realizaram-se as reações com a alga marinha Bostrychia radicans utilizando as iodoacetofenonas $\mathbf{1}$ - $\mathbf{3}$ com o objetivo de comparar o potencial biocatalítico das duas algas. Estas reações foram realizadas seguindo os mesmos procedimentos das reações com a alga Bostrychia tenella.

Os resultados das reações com a alga $B$. radicans encontram-se sumarizados na tabela 2. Os resultados das reações com a alga $B$. radicans demonstraram que a cetona $\mathbf{1}$ prosseguiu com a melhor reatividade para este biocatalisador entre esta série de cetonas. Observou-se que em todas as concentrações a cetona foi convertida, porém com um pequeno descréscimo em relação ás reações com a alga B.tenella. No entanto, na adição de $50 \mathrm{mg}$ deste substrato, a concentração do álcool (S)-4 obtida foi $42 \%$, muito similar ao resultado com B.tenella (Linhas 14, Tabela 2).

. No caso da cetona 2 , os resultados prosseguiram com pequenos valores de conversão, mesmo com o aumento das concentrações. Em relação a p-iodoacetofenona, as conversões foram observadas a partir das concentrações iniciais, porém com valores pouco expressivos.

Como observado, os resultados de conversão das cetonas $\mathbf{1}$ - $\mathbf{3}$ aumentaram com quantidade de cetonas adicionadas, isto pode ter ocorrido devido uma maior interação dos compostos com o biocatalisador. Este estudo torna claro não apenas a forte influência da posição dos substituintes nos compostos, como o fato de cada alga apresentar propriedades características em reações com esta série de cetonas. Entretanto, ambos biocatalisadores foram estereosseletivos, pois formaram alcoóis com excelentes excessos enantioméricos. 
Tabela 2. Redução de iodoacetofenonas $\mathbf{1}$ - $\mathbf{3}$ com a alga marinha Bostrychia radicans

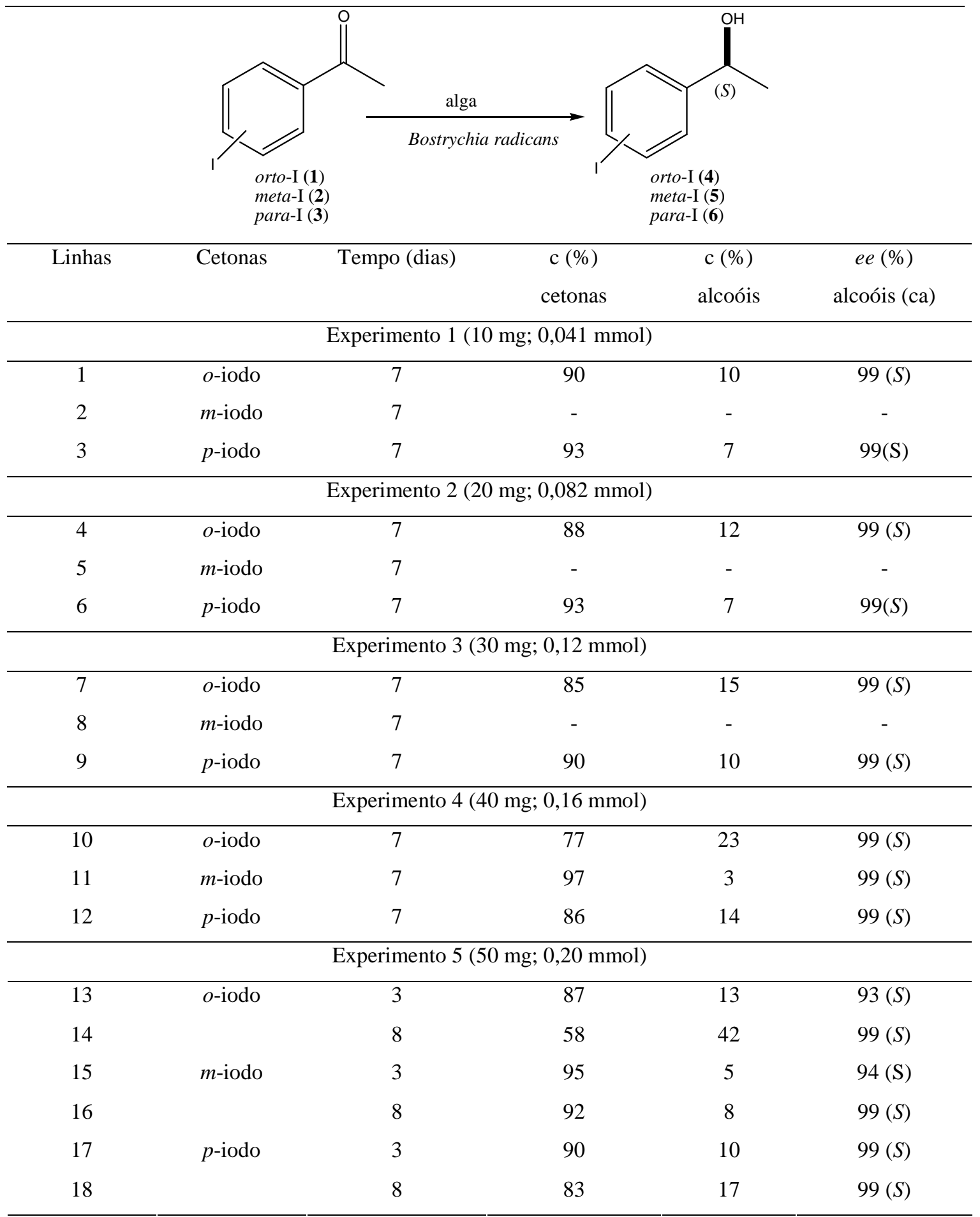

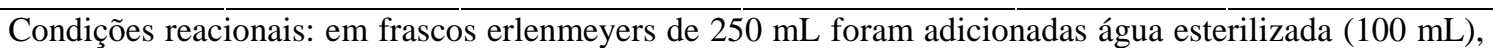
alga $B$. radicans $(5 \mathrm{~g})$, iodoacetofenonas 1 - $3(10-50 \mathrm{mg})$ dissolvidas em $300 \mu \mathrm{L}$ de DMSO. As reações foram mantidas sob agitação orbital $\left(150 \mathrm{rpm}, 32{ }^{\circ} \mathrm{C}\right)$. Alíquotas foram retiradas em tempos fixados e analisadas por cromatografia gasosa utilizando-se coluna quiral de ciclodextrina. c (\%): concentração determinada por $\mathrm{CG}$; ee $(\%)$ : excesso enantiomérico; ca: configuração absoluta. 


\section{REDUÇÃO DE IODOACETOFENONAS COM AS BACTÉRIAS ASSOCIADAS ÀS ALGAS MARINHAS Bostrychia tenella e Bosrtychia radicans}

Embora os resultados obtidos nos experimentos de 1 - 5 apresentados nas tabelas 1 e 2 pudessem ser otimizados (com adição de co-substratos, alteração de $\mathrm{pH}$ e temperatura e adição de co-solventes) com o objetivo de aumentar a produção dos alcoóis, optou-se em realizar o isolamento de possíveis microrganismos associados às algas.

O isolamento das bactérias associadas às algas Bostrychia tenella e Bostrychia radicans foi realizado em um tópico específico descrito anteriormente (Parte II, Materiais e Métodos). Aqui serão discutidas as reações biocatalíticas com a bactéria Bt01 isolada da alga $B$. tenella e a bactéria Br-01 isolada da alga B.radicans.

Após a obtenção das bactérias Bt-01 e Br-01, estas foram mantidas em incubadoras em meio sólido contendo extrato de malte 2\%. Embora sejam bactérias, todas as reações foram realizadas em meio de cultura de extrato de malte $2 \%$.

Em frascos erlemenmeyers de $250 \mathrm{~mL}$ foram adicionados $100 \mathrm{~mL}$ do meio de cultura preparado em água do mar artificial. Em seguida realizou-se o repique e o inóculo da bactéria Bt-01. Após 2-3 dias de cultivo adicionaram-se as iodoacetofenonas 1- 3 (50 mg; 0,20 mmol) no meio contendo o caldo e as células da bactéria Bt-01. Os resultados destas reações estão sumarizados na tabela 3. 
Tabela 3. Redução de iodoacetofenonas $\mathbf{1}-\mathbf{3}$ com a bactéria Bt-01 isolada da alga marinha Bostrychia tenella

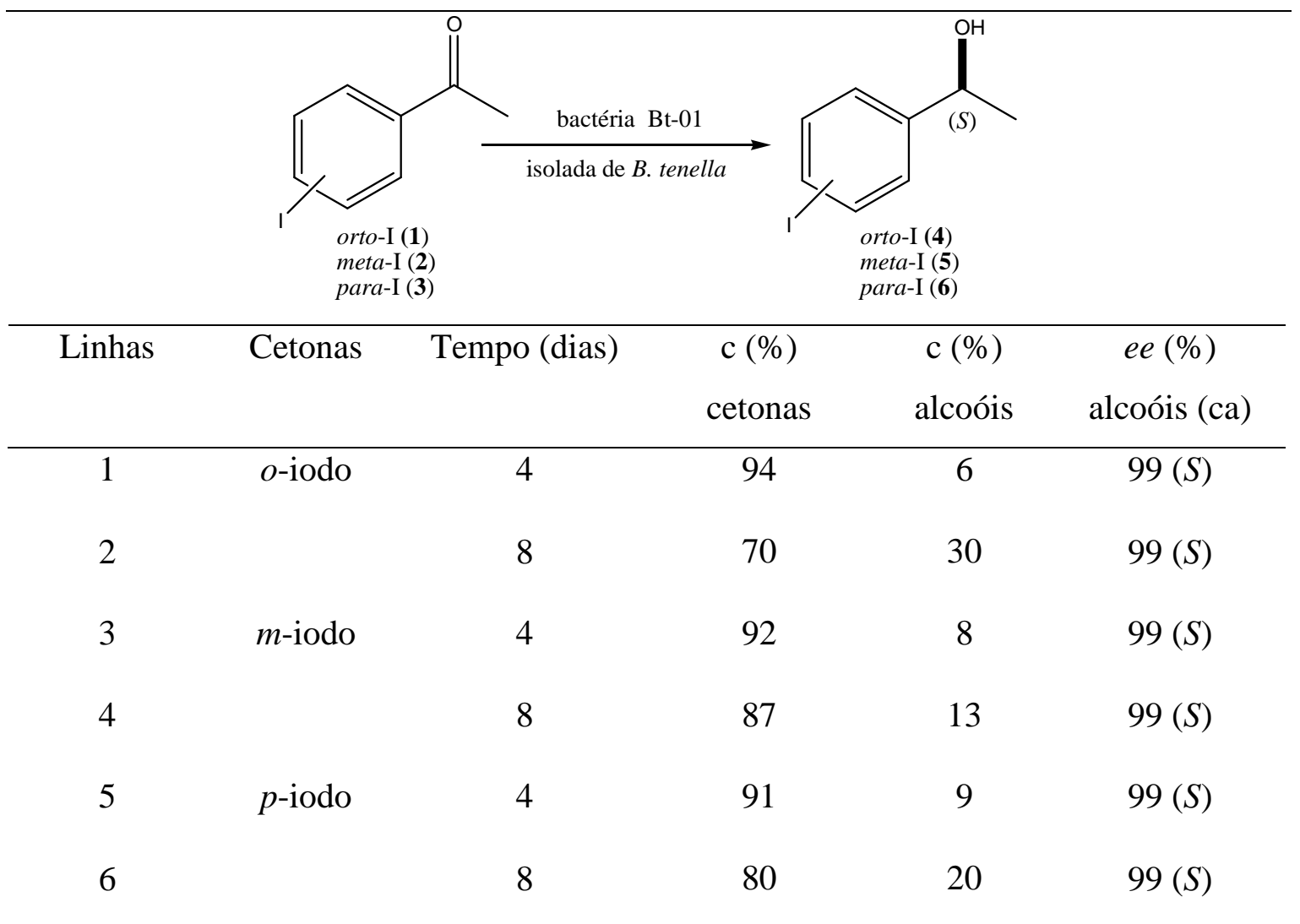

Condições reacionais: Em frascos erlenmeyers de $250 \mathrm{~mL}$ foi adicionado o meio de cultura de extrato de malte 2\% (100 mL). Cultivou-se a bactéria por 2-3 dias em agitação orbital $\left(150 \mathrm{rpm}, 32{ }^{\circ} \mathrm{C}\right)$. Após este tempo adicionou-se ao meio de cultivo $50 \mathrm{mg}(0,20 \mathrm{mmol})$ das cetonas $\mathbf{1}-\mathbf{3}$ dissolvidas em $300 \mu \mathrm{L}$ de DMSO. As reações foram mantidas sob agitação $\left(150 \mathrm{rpm}, 32^{\circ} \mathrm{C}\right)$. Alíquotas foram retiradas em tempos fixados e analisadas por cromatografia gasosa utilizando-se coluna quiral de ciclodextrina. c (\%): concentração determinada por CG; ee (\%): excesso enantiomérico; ca: configuração absoluta.

Os resultados da redução biocatalítica das iodoacetofenonas $\mathbf{1}$ - $\mathbf{3}$ com a bactéria Bt-01 apresentaram excelentes seletividades, pois os alcoóis $\mathbf{4}$ - $\mathbf{6}$ foram obtidos com excessos enantioméricos superiores a 98\% (Tabela 3).

Os resultados das reduções das iodoacetofenonas $\mathbf{1}$ - $\mathbf{3}$ com a bactéria Bt-01 foram semelhantes aos obtidos com a alga B. tenella (Tabela 1). A redução da $o$ iodoacetofenona 1 após 8 dias de reação apresentou uma conversão de $30 \%$ no respectivo álcool $(S)$-4 (Linha 2, Tabela 3). A redução da $m$-iodoacetofenona 2 também continuou apresentando baixa conversão, sendo neste caso de 13\% (Entrada 4, Tabela 
3). Enquanto que para a $p$-iodoacetofenona $\mathbf{3}$ houve um pequeno acréscimo no valor da conversão, atingindo um máximo de $20 \%$ (Linha 6, Tabela 3).

Conclui-se que os resultados obtidos tanto pela redução com a alga $B$. tenella quanto pela bactéria Bt-01 podem ser utilizados para estas reações. Entretanto a limitação do uso destes biocatalisadores restringe-se às baixas concentrações dos alcoóis formados. A baixa produção dos alcoóis pode ser ocasionada por diferentes fatores, como por exemplo, baixa concentração da enzima presente nos biocatalisadores (alga e bactéria Bt-01) e condições reacionais.

As reações de redução das iodoacetofenonas $\mathbf{1}$ - $\mathbf{3}$ também foram realizadas com a bactéria Br-01 isolada da alga Bostrychia radicans. Os resultados para estas reações estão sumarizados na tabela 4. Pode-se observar que a orto-iodoacetofenona 1 apresentou uma boa conversão e alto excesso enantiomérico para o álcool (S)-4 (Linha 2, Tabela 4). Inclusive este resultado foi superior ao obtido pela bactéria Bt-01(Linha 2, Tabela 3).

A redução da $m$-iodoacetofenona 2 foi similar tanto para a bactéria $\mathrm{Br}$-01 quanto para a bactéria Bt-01, ou seja, baixas conversões foram obtidas (Linha 4, Tabela 4). Contudo, estes resultados foram superiores aos obtidos com as algas.

A redução da $p$-iodoacetofenona 3 com a bactéria $\mathrm{Br}-01$ apresentou melhor conversão, atingindo 48\% (Linha 6, Tabela 4), quando comparado com a bactéria Bt-01 que foi de $20 \%$ (Linha 6, Tabela 3).

Na figura 8 têm-se o cromatograma da reação da $o$-iodoacetofenona $\mathbf{1}$ com a com a bactéria Br-01 obtido por cromatografia gasosa em coluna quiral de ciclodextrina. 
Tabela 4. Redução de iodoacetofenonas 1 - 3 com a bactéria Br-01 isolada da alga marinha Bostrychia radicans

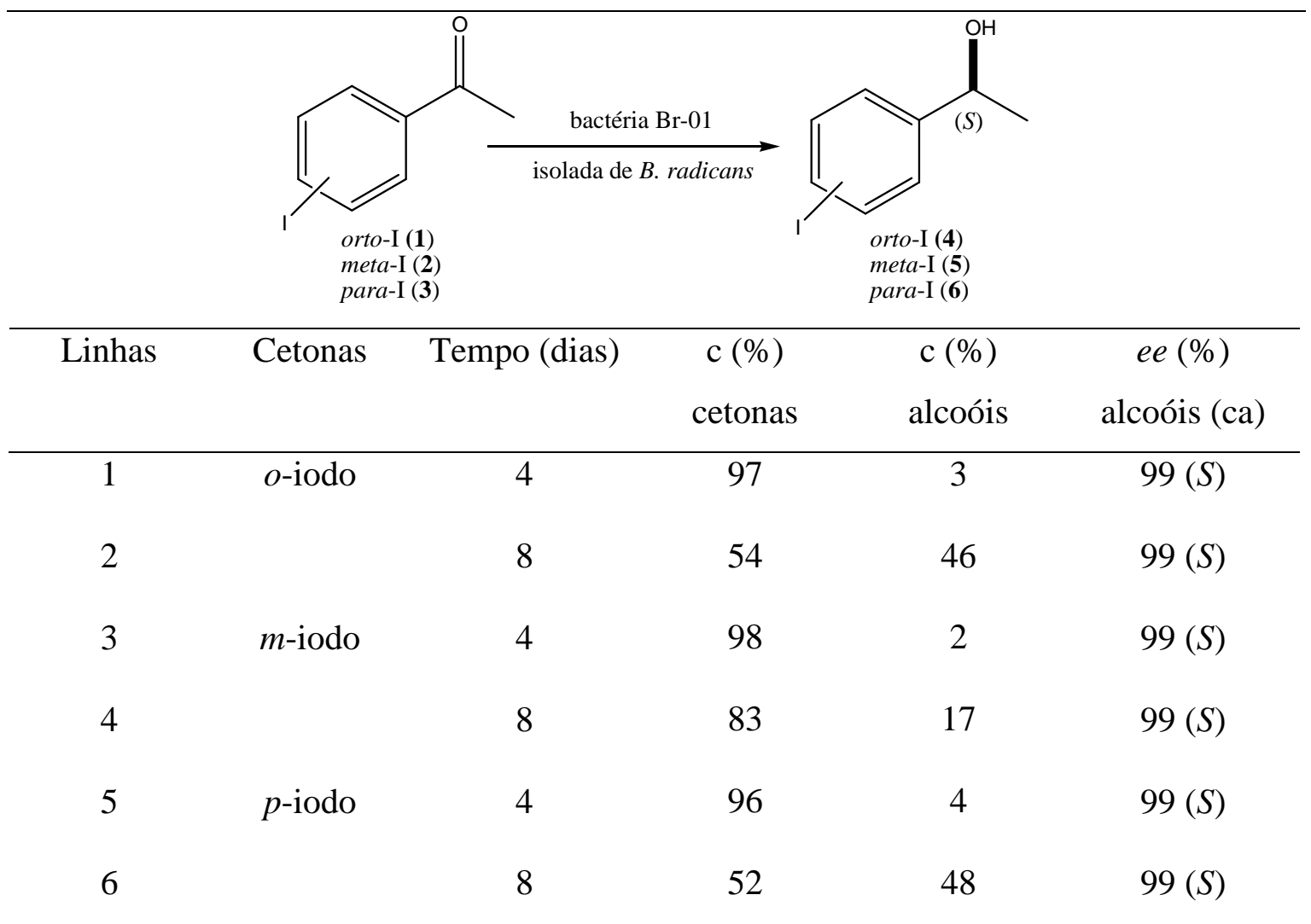

Condições reacionais: em frascos erlenmeyers de $250 \mathrm{~mL}$ foi adicionado o meio de cultura de extrato de malte $2 \%$ em $100 \mathrm{~mL}$ de água do mar artificial ( $\mathrm{pH}$ 8). Cultivou-se a bactéria por 2-3 dias em agitação orbital (150 rpm, $\left.32{ }^{\circ} \mathrm{C}\right)$. Após este tempo adicionou-se $50 \mathrm{mg}(0,20 \mathrm{mmol})$ das cetonas $\mathbf{1}-\mathbf{3}$ dissolvidas em $300 \mu \mathrm{L}$ de DMSO. As reações foram mantidas sob agitação $\left(150 \mathrm{rpm}, 32{ }^{\circ} \mathrm{C}\right)$. Alíquotas foram retiradas em tempos fixados e analisadas por cromatografia gasosa utilizando-se coluna quiral de ciclodextrina. c (\%): concentração determinada por CG; ee (\%): excesso enantiomérico; ca: configuração absoluta. 


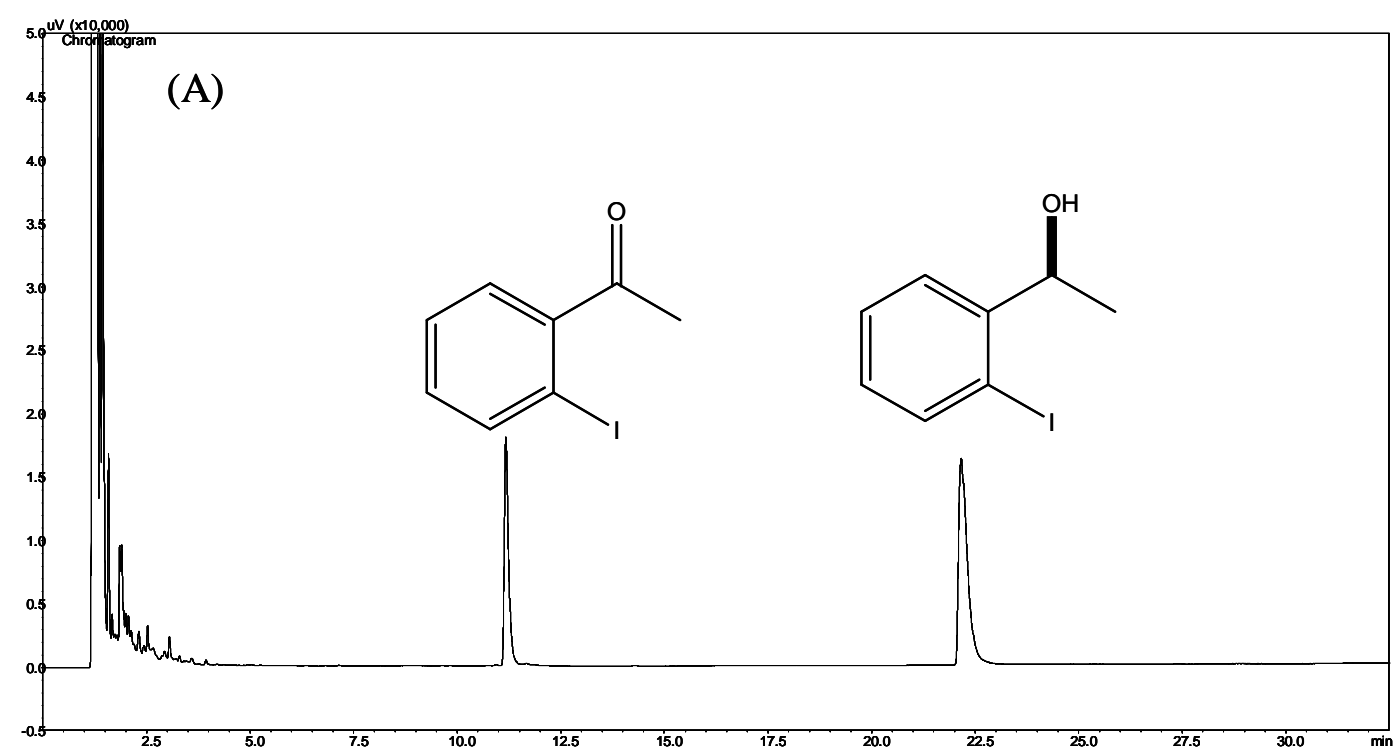

Figura 8. (A) Cromatograma obtido por CG. Reação da $o$-iodoacetofenona 1 com a bactéria Br-01 isolada da alga Bostrychia radicans (8 dias de reação) 


\section{REDUÇÃO DE ORTO-ACETOFENONAS COM A ALGA MARINHA}

\section{Bostrychia tenella}

Embora os resultados alcançados nas reduções das iodoacetofenonas $\mathbf{1}$ - $\mathbf{3}$ com as algas $B$. tenella e $B$. radicans foram interessantes, observou-se que ocorreram baixas conversões, principalmente quando o substituinte iodo estava ligado nas posições meta e para do anel aromático. Assim, resolveu-se ampliar estes estudos com novos substratos contendo diferentes substituintes, porém somente na posição orto, uma vez que a $o$-iodoacetofenona 1 apresentou melhores resultados, quando comparados com os grupamentos em posições meta e para.

As cetonas utilizadas foram selecionadas em função da disponibilidade e da resolução enantiomérica dos alcoóis em coluna quiral, uma vez que o objetivo deste trabalho foi investigar o potencial enzimático das algas e dos microrganismos marinhos na produção de alcoóis enantiomericamente puros. As cetonas empregadas foram a $o$ fluoracetofenona 7, $o$-cloroacetofenona $8, o$-bromoacetofenona 9 e a $o$-nitrocetofenona 10.

As reações enzimáticas com os novos derivados de $o$-acetofenonas $\mathbf{7 - 1 0}$ foram conduzidas em frascos erlenmeyers de $250 \mathrm{~mL}$ onde se adicionou $100 \mathrm{~mL}$ de água esterilizada e a alga $B$. tenella $(5 \mathrm{~g})$. As quantidades de cetonas adicionadas foram: cetona 7(50 mg; 0,36 mmol); 8 (50 $\mathbf{~ m g ; ~ 0 , 3 2 ~ m m o l ) ; ~} 9$ (50 mg; 0,25 mmol); 10 (50 mg; 0,30 mmol).

Após o preparo das reações, os frascos foram mantidos sob agitação orbital (150 $\mathrm{rpm}, 32^{\circ} \mathrm{C}$ ). Amostras das reações foram retiradas em tempos determinados com pipetas de Pasteur, filtradas, extraídas com acetato de etila e analisadas por cromatografia 
gasosa com coluna capilar de ciclodextrina. Os resultados destas reações encontram-se sumarizados na tabela 5 .

Tabela 5. Redução de orto-acetofenonas 7 - 10 com a alga marinha Bostrychia tenella

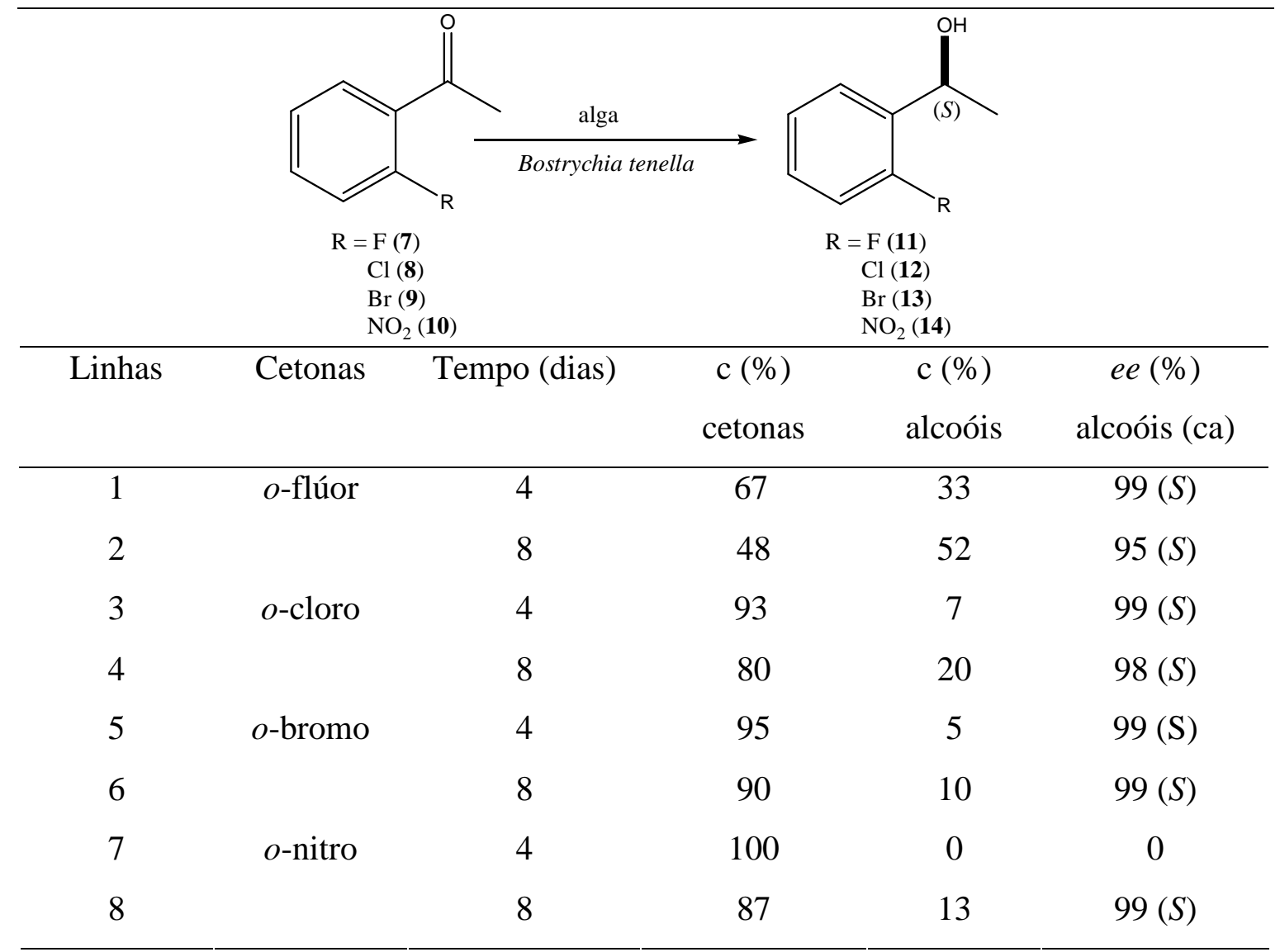

Condições reacionais: em frascos erlenmeyers de $250 \mathrm{~mL}$ foram adicionados $100 \mathrm{~mL}$ de água esterilizada, a alga B. tenella (5 g) e $50 \mathrm{mg}$ das cetonas 7 - 10 dissolvidas em $300 \mu \mathrm{L}$ de DMSO. As reações foram conduzidas em agitação orbital $\left(150 \mathrm{rpm}, 32{ }^{\circ} \mathrm{C}\right)$. Alíquotas foram retiradas em tempos fixados e analisadas por cromatografia gasosa utilizando-se coluna quiral de ciclodextrina. c (\%): concentração determinada por CG; ee (\%): excesso enantiomérico; ca: configuração absoluta.

De acordo com os dados obtidos observaram-se também altas seletividades para os alcoóis 11 - 14. Entretanto, para a $o$-fluoracetofenona 7 ocorreu um pequeno decréscimo no excesso enantiomérico (Linha 2, Tabela 5). Enquanto que a $o$ cloroacetofenona $\mathbf{8}, o$-bromoacetofenona 9 e $o$-nitroacetofenona $\mathbf{1 0}$ foram reduzidas nos respectivos alcoóis com excessos enantioméricos superiores a 98\%, porém com baixas conversões (Linhas 4, 6, e 8, Tabela 5). 
Nas figuras 9 - 12 têm-se os cromatogramas das cetonas $\mathbf{7}$ - $\mathbf{1 0}$ e dos alcoóis racêmicos 11 - 14 obtidos por cromatografia gasosa em coluna capilar de ciclodextrina.
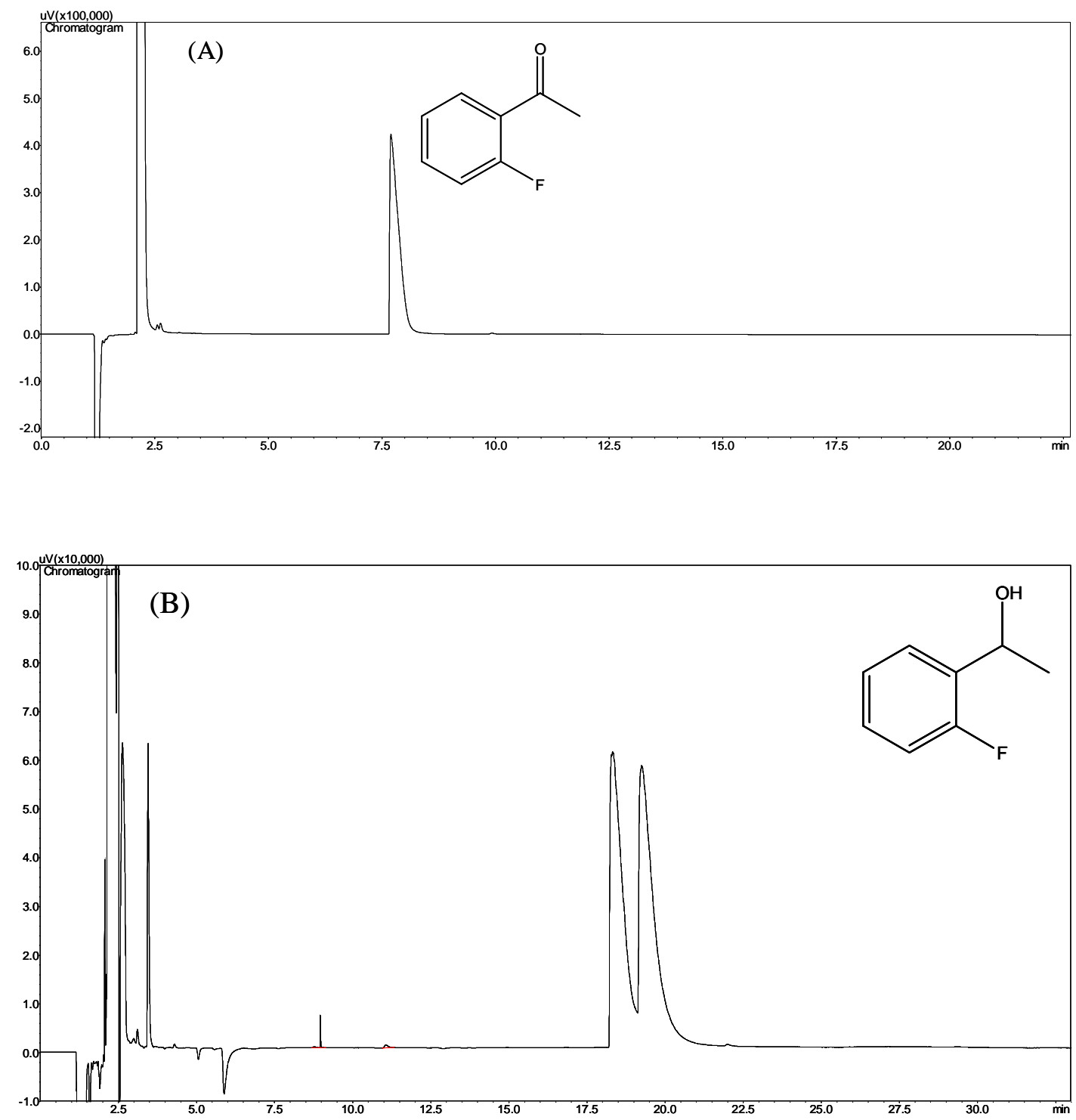

Figura 9. Cromatogramas obtidos por CG. (A) padrão da $o$-fluoroacetofenona 7 (B) padrão do 1-(2-fluorfenil)etanol rac-11 

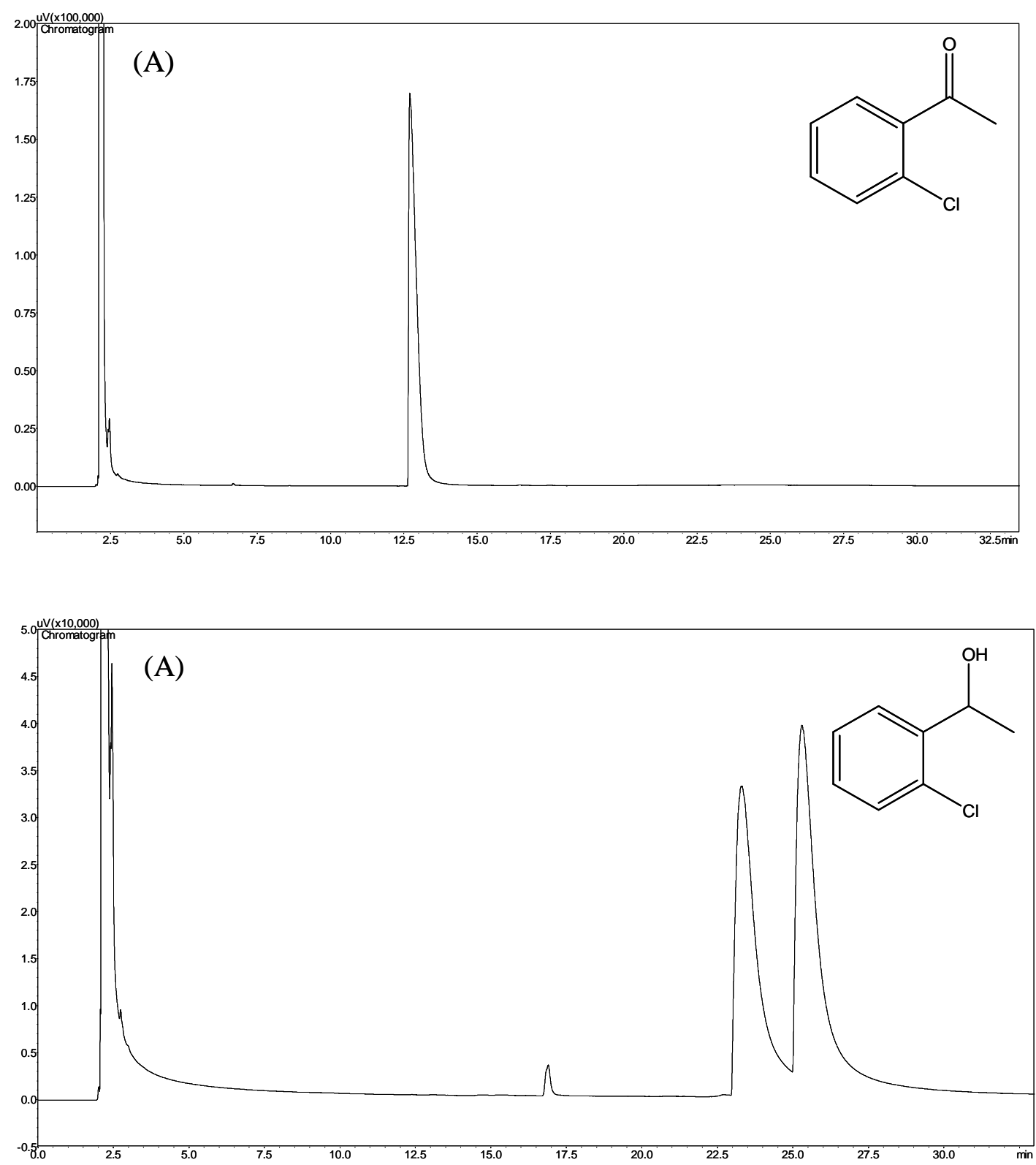

Figura 10. Cromatogramas obtidos por CG. (A) padrão da $o$-cloroacetofenona 8 (B) padrão do 1-(2-clorofenil)etanol rac-12 

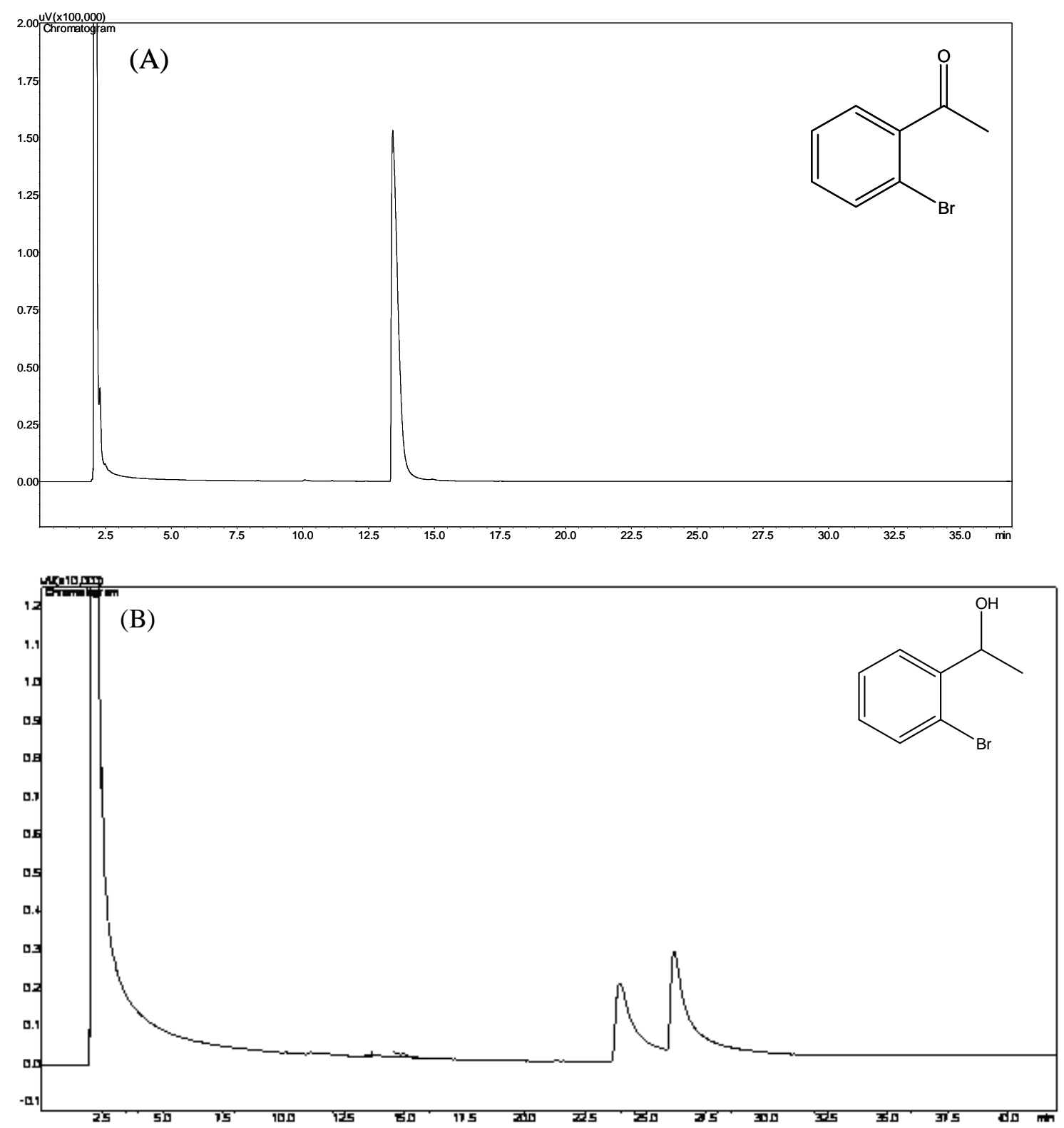

Figura 11. Cromatogramas obtidos por CG. (A) padrão da $o$-bromoacetofenona 9 (B) padrão do 1-(2-bromofenil)etanol rac-13 

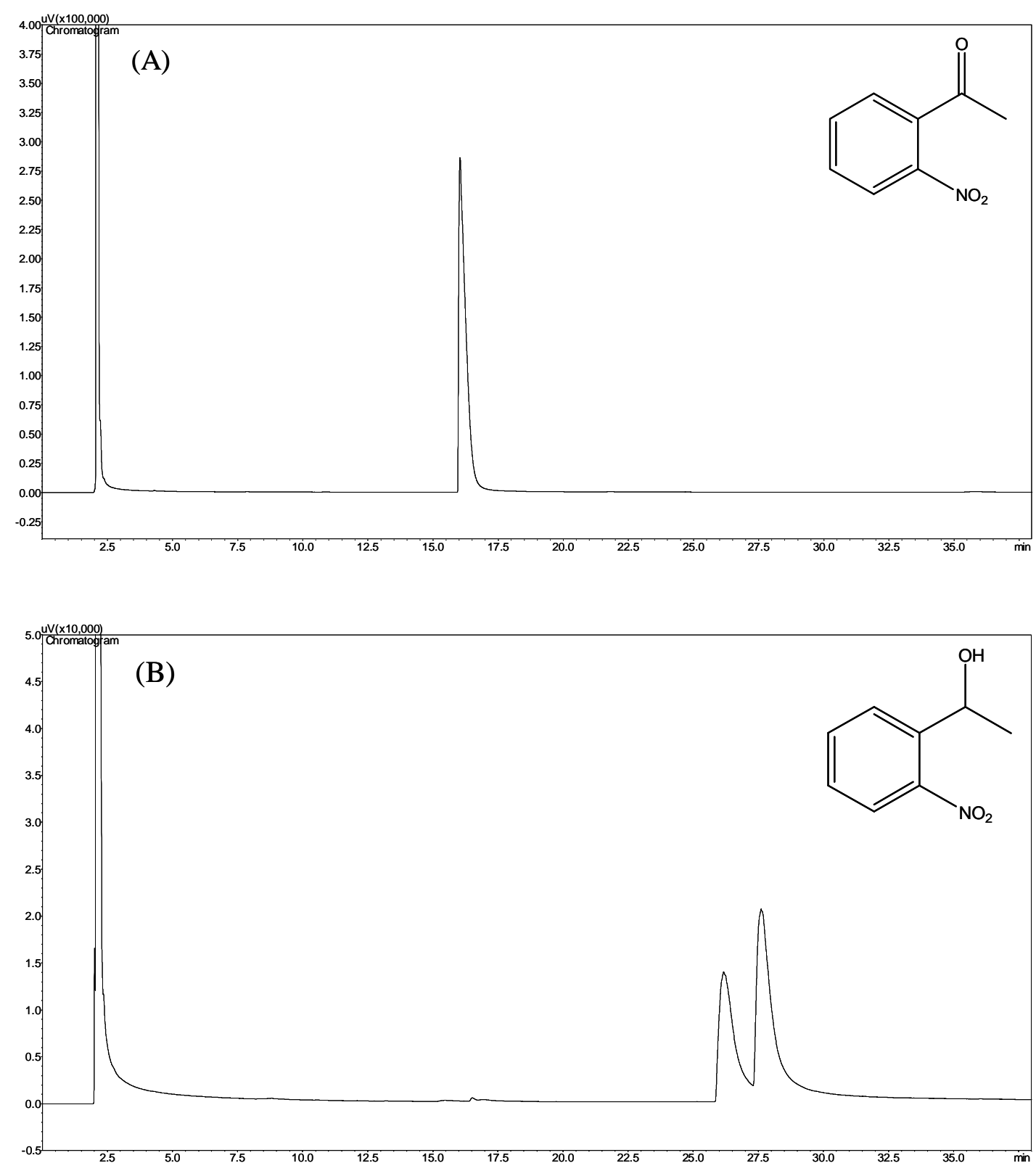

Figura 12. Cromatogramas obtidos por CG. (A) padrão da $o$-nitroacetofenona 10 (B) padrão do 1-(2-nitrofenil)etanol rac-14 


\section{REDUÇÃO DE DERIVADOS DE ACETOFENONAS COM OS \\ MICRORGANISMOS ISOLADOS DA ALGA MARINHA}

\section{Bostrychia radicans}

Como descrito em materiais e métodos anteriormente, realizou-se também as reações de biocatálise com os microrganismos isolados da alga $B$. radicans (bactéria $\mathrm{Br}$ 01 e os fungos $\mathrm{Br}-09, \mathrm{Br}-23, \mathrm{Br}-27$ e $\mathrm{Br}-61)$. As reações de redução foram realizadas com as $o$-acetofenonas 7 - 10. Na tabela 6, encontram-se os dados das reações de redução das $O$-acetofenonas $\mathbf{7} \mathbf{- 1 0}$ com a bactéria $\mathrm{Br}-01$.

Tabela 6. Redução de $o$-acetofenonas $\mathbf{7}$ - $\mathbf{1 0}$ com a bactéria $\mathrm{Br}-01$ isolada da alga marinha Bostrychia radicans

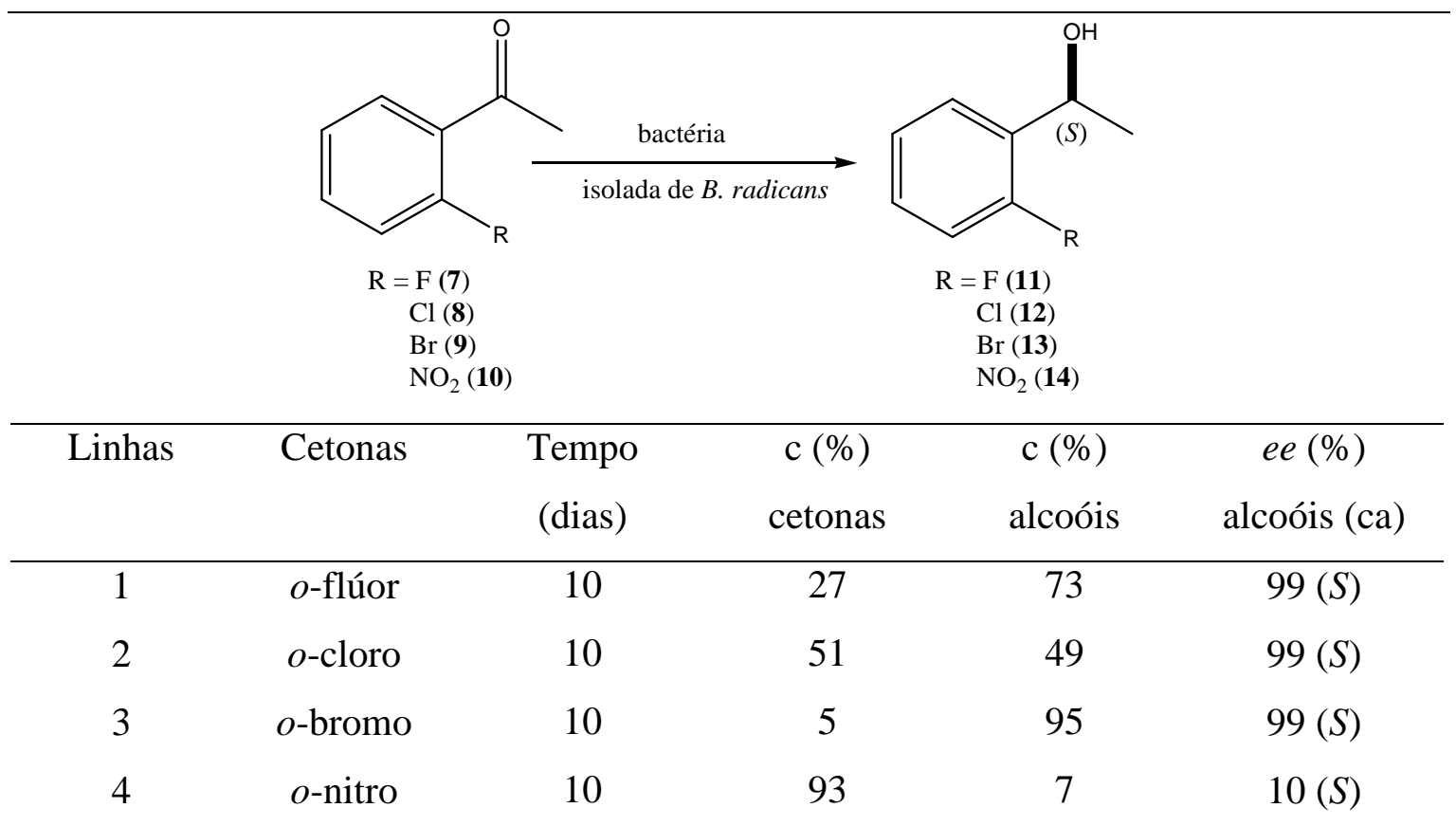

Condições reacionais: em frascos erlenmeyers de $250 \mathrm{~mL}$ foi adicionado o de meio de cultura de extrato de malte 2\% (100 mL). Cultivou-se a bactéria Br-01 por 2-3 dias em agitação orbital $\left(150 \mathrm{rpm}, 32{ }^{\circ} \mathrm{C}\right)$. Após este período adicionou-se $50 \mathrm{mg}$ das cetonas 7 - 10 dissolvidas em $300 \mu \mathrm{L}$ de DMSO. As reações foram mantidas em agitação orbital $\left(150 \mathrm{rpm}, 32{ }^{\circ} \mathrm{C}\right)$. Alíquotas foram retiradas em tempos fixados e analisadas por cromatografia gasosa utilizando-se coluna quiral de ciclodextrina. c (\%): concentração determinada por CG; ee (\%): excesso enantiomérico; ca: configuração absoluta. 
A bactéria $\mathrm{Br}-01$ reduziu as orto-acetofenonas 7 - 9 com excelentes excessos enantioméricos e com boas taxas de conversões (Linhas 1 - 3, Tabela 6). Enquanto que a $p$-nitroacetofenona $\mathbf{1 0}$ foi discretamente reduzida, obtendo-se $7 \%$ de conversão e $10 \%$ de excesso enantiomérico para o correspondente álcool formado (Linha 4, tabela 6). $\mathrm{O}$ melhor resultado foi com $o$-bromoacetofenona 9, pois foi reduzida no álcool $(S)$-13 com 95\% de conversão e $99 \%$ de excesso enantiomérico. Conclui-se que a bactéria $\mathrm{Br}-01$ isolada da alga marinha Bostrychia radicans tem potencial para reduzir derivados de $o$ acetofenonas. Assim, este trabalho demonstra que a busca por novas enzimas para atuarem como biocatalisadores é promissor.

Ainda, dando continuidade aos trabalhos, reações de redução das iodoacetofenonas $\mathbf{1 - 3}$ e orto-acetofenonas $\mathbf{7 - 1 0}$ foram realizadas com as linhagens de fungos (Br-09, Br-23, Br-27 e Br-61) isolados da alga B. radicans.

As reações de biocatálise foram realizadas fazendo-se os inóculos dos fungos em meio de cultura líquido de extrato de malte $2 \%$. Após o crescimento dos fungos por 3 dias em agitação orbital adicionaram-se $50 \mathrm{mg}$ das cetonas (1 - 3 e $\mathbf{7}$-10) dissolvidas em dimetilsufóxido (DMSO). As reações foram mantidas sob agitação e temperatura controladas $\left(150 \mathrm{rpm}, 32^{\circ} \mathrm{C}\right)$. Alíquotas foram retiradas em tempos determinados e analisados por cromatografia gasosa utilizando-se como fase estacionária coluna quiral de ciclodextrina. Os resultados obtidos estão sumarizados nas tabelas 7 e 8 .

As linhagens de fungos $\mathrm{Br}-09$ e $\mathrm{Br}-61$ catalisaram a redução da $o$ iodoacetofenona $\mathbf{1}$ no correspondente álcool $(R)$-11 com excelentes valores de excessos enantioméricos (Linhas 1 e 4, Tabela 7). Entretanto a conversão do álcool $(R)$-11 com a linhagem Br-09 foi superior à linhagem Br-61 (Linhas 1 e 4, Tabela 7). Este álcool apresentou seletividade anti-Prelog, pois sua configuração absoluta foi $R$. 
A reação da $p$-iodoacetofenona 3 com a linhagem $\mathrm{Br}-09$ apresentou altos valores de conversão e excesso enantiomérico para o álcool (S)-14 (Linha 3, Tabela 7). Contudo, com a linhagem Br-61 ocorreu um acentuado decréscimo na conversão e na seletividade (Linha 6, Tabela 7). Nestes experimentos, não foram realizadas reações com a $m$-iodoacetofenona 2 com os fungos Br-09 e Br-61.

Tabela 7. Redução de iodoacetofenonas $\mathbf{1}$ - $\mathbf{3}$ com os fungos $\mathrm{Br}-09$ e Br-61 isolados da alga marinha Bostrychia radicans

\begin{tabular}{|c|c|c|c|c|c|}
\hline & $\begin{array}{l}\text { orto } \\
\text { metc } \\
\text { parc }\end{array}$ & $\begin{array}{r}\text { fungo } \\
\text { de Bostry }\end{array}$ & cans & $\sum_{(R) \text { ou }}^{\mathrm{OH}^{\mathrm{H}}}$ & \\
\hline \multirow[t]{2}{*}{ Linhas } & Cetonas & Tempo & $\mathrm{c}(\%)$ & $\mathrm{c}(\%)$ & $e e(\%)$ \\
\hline & & (dias) & cetonas & alcoóis & alcoóis (ca) \\
\hline \multicolumn{6}{|c|}{ Fungo Br-09 } \\
\hline 1 & $O$-iodo & 10 & 0 & 100 & $99(R)$ \\
\hline 2 & $m$-iodo & - & - & - & - \\
\hline 3 & $p$-iodo & 10 & 2 & 98 & $99(S)$ \\
\hline \multicolumn{6}{|c|}{ Fungo Br-61 } \\
\hline 4 & $o$-iodo & 10 & 32 & 68 & $99(R)$ \\
\hline 5 & $m$-iodo & - & - & - & - \\
\hline 6 & $p$-iodo & 10 & 70 & 30 & $42(S)$ \\
\hline
\end{tabular}

Condições reacionais: em frascos erlenmeyers de $250 \mathrm{~mL}$ foi adicionado o meio de cultura de extrato de malte $2 \%$ em água do mar artificial $(100 \mathrm{~mL})$. Cultivaram-se os fungos por 2-3 dias em agitação orbital (150 rpm, $\left.32{ }^{\circ} \mathrm{C}\right)$. Após este tempo adicionou-se $50 \mathrm{mg}(0,20 \mathrm{mmol})$ das cetonas $\mathbf{1}-\mathbf{3}$ dissolvidas em 300 $\mu \mathrm{L}$ de DMSO. As reações foram mantidas em agitação orbital $\left(150 \mathrm{rpm}, 32{ }^{\circ} \mathrm{C}\right)$. Alíquotas foram retiradas em tempos fixados e analisadas por cromatografia gasosa utilizando-se coluna quiral de ciclodextrina. c (\%): concentração determinada por CG; ee (\%): excesso enantiomérico; ca: configuração absoluta. 
As reações com as $o$-acetofenonas $\mathbf{7 - 1 0}$ apresentaram bons resultados de conversões e seletividades com as quatro linhagens de fungos utilizadas. Os resultados destas reações estão sumarizados na tabela 8 .

O fungo Br-09 reduziu todas as $o$-acetofenonas $\mathbf{7}-\mathbf{1 0}$ com excelentes conversões (Linhas 1 - 4, Tabela 8). Este foi fungo foi que apresentou melhores conversões para todos os substratos utilizados no decorrer deste trabalho. As seletividades também foram excelentes, sendo todas superiores a 98\%, exceto para a $o$ fluoracetofenona 7 que foi de $42 \%$ (Linha 1, Tabela 8).

O fungo Br-23 também apresentou excelentes conversões e seletividades para as reações que catalisaram (Linhas 5 - 8, Tabela 8), exceto para a $o$-cloroacetofenona 8 que apresentou uma baixa conversão no álcool (Linha 6, Tabela 8). Este fungo também apresentou uma boa seletividade para o álcool $o$-fluorfeniletanol 11, cujo excesso enantiomérico foi de 90\% (Linha 5, Tabela 8).

O fungo $\mathrm{Br}-27$ apresentou um resultado similar ao microrganismo $\mathrm{Br}-23$, ou seja, bons valores de seletividades e conversões para as reações, exceto para $o$ cloroacetofenona 8, cuja conversão foi de $4 \%$ (Linhas 9 -12, Tabela 8 ). O $o$ bromofeniletanol 13 foi o único álcool obtido com configuração absoluta $R$ com os fungos $\mathrm{Br}-23$ e $\mathrm{Br}-27$.

O fungo Br-61 reduziu com boas seletividades e conversões a $o$ fluoracetofenona 7 e a $o$-nitroacetofenona 10. Enquanto a $o$-cloroacetofenona 8 e a $o$ bromoacetofenona 9 não foram convertidas.

A $o$-fluoracetofenona 4 foi o único substrato que levou a um decréscimo no excesso enantiomérico do álcool $(S)-8$ formado, possivelmente devido ao menor tamanho do átomo de flúor em posição orto. 
$\mathrm{Na}$ figura 14 tem-se os cromatogramas das reações de redução da $o$ fluoracetofenona 7 e $o$-nitroacetofenona $\mathbf{1 0}$ obtidos com o fungo $\mathrm{Br}-09$ isolado da alga marinha $B$. radicans.

Tabela 8. Redução de $o$-acetofenonas 7 - 10 com os fungos Br-09, Br-23, Br-27 e Br-61 isolados da alga marinha Bostrychia radicans

\begin{tabular}{|c|c|c|c|c|c|}
\hline \multirow{4}{*}{ Linhas } & \multirow{2}{*}{\multicolumn{2}{|c|}{$\begin{array}{l}\mathrm{R}=\mathrm{F}(\mathbf{7}) \\
\mathrm{Cl}(\mathbf{8}) \\
\mathrm{Br}(\mathbf{9}) \\
\mathrm{NO}_{2}(\mathbf{1 0})\end{array}$}} & \multirow{2}{*}{\multicolumn{2}{|c|}{$\begin{aligned} \mathrm{R}= & \mathrm{F}(\mathbf{1 1}) \\
& \mathrm{Cl}(\mathbf{1 2}) \\
& \mathrm{Br}(\mathbf{1 3}) \\
& \mathrm{NO}_{2}(\mathbf{1 4})\end{aligned}$}} & \multirow{4}{*}{$\begin{array}{c}e e(\%) \\
\text { alcoóis(ca) }\end{array}$} \\
\hline & & & & & \\
\hline & \multirow[t]{2}{*}{ Cetonas } & \multirow{2}{*}{$\begin{array}{l}\text { Tempo } \\
\text { (dias) }\end{array}$} & \multirow{2}{*}{$\begin{array}{l}\mathrm{c}(\%) \\
\text { cetonas }\end{array}$} & \multirow{2}{*}{$\begin{array}{l}\mathrm{c}(\%) \\
\text { alcoóis }\end{array}$} & \\
\hline & & & & & \\
\hline \multicolumn{6}{|c|}{ Fungo Br-09 } \\
\hline 1 & $o$-flúor & 10 & 1 & 99 & $42(S)$ \\
\hline 2 & $o$-cloro & 10 & 0 & 100 & $99(S)$ \\
\hline 3 & $o$-bromo & 10 & 0 & 100 & $99(S)$ \\
\hline 4 & $o$-nitro & 10 & 10 & 90 & $99(S)$ \\
\hline \multicolumn{6}{|c|}{ Fungo Br-23 } \\
\hline 5 & $o$-flúor & 10 & 23 & 77 & $90(S)$ \\
\hline 6 & $o$-cloro & 10 & 92 & 8 & $99(S)$ \\
\hline 7 & $o$-bromo & 10 & 4 & 96 & $90(R)$ \\
\hline 8 & $o$-nitro & 10 & 8 & 92 & $98(S)$ \\
\hline \multicolumn{6}{|c|}{ Fungo Br-27 } \\
\hline 9 & $o$-flúor & 10 & 1 & 99 & $80(S)$ \\
\hline 10 & $o$-cloro & 10 & 96 & 4 & $99(S)$ \\
\hline 11 & $o$-bromo & 10 & 24 & 76 & $99(R)$ \\
\hline 12 & $o$-nitro & 10 & 30 & 70 & $99(S)$ \\
\hline \multicolumn{6}{|c|}{ Fungo Br-61 } \\
\hline 13 & $o$-flúor & 10 & 17 & 83 & $99(S)$ \\
\hline 14 & $o$-cloro & 10 & 100 & 0 & - \\
\hline 15 & $o$-bromo & 10 & 100 & 0 & - \\
\hline 16 & $o$-nitro & 10 & 70 & 30 & $99(S)$ \\
\hline
\end{tabular}

Condições reacionais: Em frascos erlenmeyers de $250 \mathrm{~mL}$ foi adicionado o meio de cultura de extrato de malte $2 \%$ em água do mar artificial $(100 \mathrm{~mL})$. Cultivaram-se os fungos por 2-3 dias em agitação orbital $\left(150 \mathrm{rpm}, 32{ }^{\circ} \mathrm{C}\right)$. Após este tempo adicionou-se $50 \mathrm{mg}$ das cetonas $\mathbf{7}-\mathbf{1 0}$ dissolvidas em $300 \mu \mathrm{L}$ de 
DMSO. As reações foram mantidas em agitação orbital $\left(150 \mathrm{rpm}, 32{ }^{\circ} \mathrm{C}\right)$. Alíquotas foram retiradas em tempos fixados e analisadas por cromatografia gasosa utilizando-se coluna quiral de ciclodextrina. c (\%): concentração determinada por CG; ee (\%): excesso enantiomérico; ca: configuração absoluta.
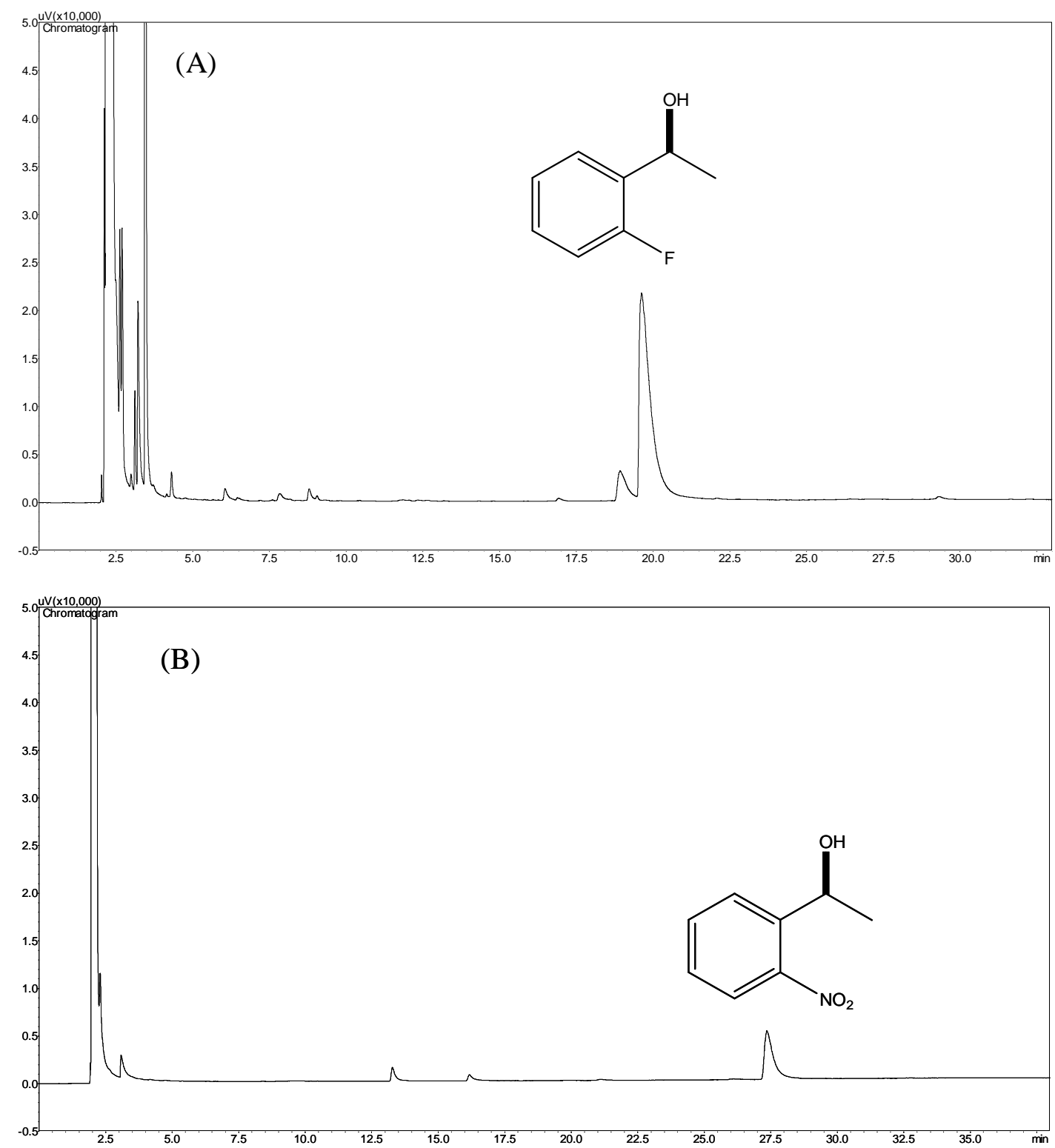

Figura 14. Cromatogramas obtidos por $\mathrm{CG}$ das reações de redução com o fungo Br-09 isolado da alga $B$. radicans com 10 dias de reação. (A) $o$-fluorfeniletanol 7 (B) $o$-nitrofeniletanol 10 


\section{REDUÇÃO DE DERIVADOS DE ACETOFENONAS COM FUNGOS \\ ISOLADOS DA ALGA Sargassum sp.}

O isolamento dos fungos da alga Sargassum sp. estão descritos em materiais e métodos.Foi realizada uma triagem com quatro fungos (SMA2-C, SMA2-8, SMA2-58, SGPY-41) isolados da alga Sargassum sp. frente a o-acetofenonas 7 - 10. Realizaramse os cultivos dos microrganismos em $100 \mathrm{~mL}$ de meio de extrato de malte $2 \%$ por $2-3$ dias. Posteriormente adicionaram-se $50 \mathrm{mg}$ das $o$-acetofenonas 7 - 10 solubilizadas em $300 \mu \mathrm{L}$ de dimetilsulfóxido. As reações foram mantidas sob agitação $\left(150 \mathrm{rpm}, 32{ }^{\circ} \mathrm{C}\right)$ por 10 dias. Após este período as reações foram extraídas com acetato de etila e analisadas por cromatografia gasosa utilizando-se coluna quiral de ciclodextrina. Os resultados obtidos estão sumarizados na tabela 9 . 
Tabela 9. Redução de $o$-acetofenonas 7 - 10 com fungos isolados da alga marinha Sargassum sp.

\begin{tabular}{|c|c|c|c|c|c|}
\hline \multirow[b]{2}{*}{ Linhas } & \multicolumn{2}{|c|}{$\begin{aligned} \mathrm{R}= & \mathrm{F}(\mathbf{7}) \\
& \mathrm{Cl}(\mathbf{8}) \\
& \mathrm{Br}(\mathbf{9}) \\
& \mathrm{NO}_{2}(\mathbf{1 0})\end{aligned}$} & \multicolumn{2}{|c|}{$\begin{array}{c}\mathrm{R}=\mathrm{F}(\mathbf{1 1}) \\
\mathrm{Cl}(\mathbf{1 2}) \\
\mathrm{Br}(\mathbf{1 3}) \\
\\
\mathrm{NO}_{2}(\mathbf{1 4})\end{array}$} & \multirow[b]{2}{*}{$\begin{array}{c}e e(\%) \\
\text { alcoóis (ca) }\end{array}$} \\
\hline & Cetonas & $\begin{array}{l}\text { Tempo } \\
\text { (dias) }\end{array}$ & $\begin{array}{l}\mathrm{c}(\%) \\
\text { cetonas }\end{array}$ & $\begin{array}{l}\text { c (\%) } \\
\text { alcoóis }\end{array}$ & \\
\hline \multicolumn{6}{|c|}{ Fungo SMA2-C } \\
\hline 1 & $o$-flúor & 10 & 2 & 98 & $80(R)$ \\
\hline 2 & $o$-cloro & 10 & 22 & 78 & $99(S)$ \\
\hline 3 & $o$-bromo & 10 & 93 & 7 & $99(S)$ \\
\hline 4 & $o$-nitro & 10 & 95 & 5 & $99(S)$ \\
\hline \multicolumn{6}{|c|}{ Fungo SMA2-8 } \\
\hline 5 & $o$-flúor & 10 & 15 & 85 & $94(R)$ \\
\hline 6 & $o$-cloro & 10 & 2 & 98 & $99(S)$ \\
\hline 7 & $o$-bromo & 10 & 54 & 46 & $99(S)$ \\
\hline 8 & $o$-nitro & 10 & 85 & 15 & $98(S)$ \\
\hline \multicolumn{6}{|c|}{ Fungo SMA2-58 } \\
\hline 9 & $o$-flúor & 10 & 2 & 98 & $77(S)$ \\
\hline 10 & $o$-cloro & 10 & 3 & 97 & $99(S)$ \\
\hline 11 & $o$-bromo & 10 & 68 & 32 & $99(S)$ \\
\hline 12 & $o$-nitro & 10 & 90 & 10 & $98(S)$ \\
\hline \multicolumn{6}{|c|}{ Fungo SGPY-41 } \\
\hline 13 & $o$-flúor & 10 & 2 & 98 & $80(S)$ \\
\hline 14 & $o$-cloro & 10 & 22 & 78 & $99(S)$ \\
\hline 15 & $o$-bromo & 10 & 93 & 7 & $99(S)$ \\
\hline 16 & $o$-nitro & 10 & 95 & 5 & $98(S)$ \\
\hline
\end{tabular}

Condições reacionais: em frascos erlenmeyers de $250 \mathrm{~mL}$ foi adicionado o meio de cultura de extrato de malte $2 \%$ em água do mar artificial $(100 \mathrm{~mL})$. Cultivaram-se os fungos por 2-3 dias em agitação orbital $\left(150 \mathrm{rpm}, 32{ }^{\circ} \mathrm{C}\right)$. Após este tempo adicionaram-se $50 \mathrm{mg}$ das cetonas $\mathbf{7}-\mathbf{1 0}$ dissolvidas em $300 \mu \mathrm{L}$ de DMSO. As reações foram mantidas em agitação orbital $\left(150 \mathrm{rpm}, 32{ }^{\circ} \mathrm{C}\right)$. Alíquotas foram retiradas em tempos fixados e analisadas por cromatografia gasosa utilizando-se coluna quiral de ciclodextrina. c $(\%)$ : concentração determinada por $\mathrm{CG}$; ee (\%): excesso enantiomérico; ca: configuração absoluta. 
Todos os fungos isolados da alga Sargassum sp. (SMA2-C, SMA2-8, SMA2-58, GPY-41) catalisaram a redução da $o$-fluoracetofenona 7 com excelente conversão, porém, os excessos enantioméricos foram inferiores a 98\% para o correspondente álcool (R)-11 (Linhas 1, 5, 9 e 13, Tabela 9). Todos os fungos levaram a formação preferencial do $R$-enantiômero.

Os fungos SMA2-C e GPY-41 catalisaram a redução da $o$-cloroacetofenona 8 com menores conversões que os fungos SMA2-8 e SMA2-58, porém todos forneceram altos excessos enantioméricos para o álcool (S)-12 (Linhas 2, 6, 10 e 14, Tabela 9).

O melhor resultado da cetona $o$-bromoacetofenona foi obtido com o fungo SMA2-8, com conversões de $46 \%$ ao respectivo 13 (S)-álcool, com 99\% de excesso enantiomérico (Linha 7, Tabela 9).

Concluiu-se através destes experimentos que os quatro fungos isolados da alga Sargassum sp. catalisaram a redução das $o$-acetofenonas $\mathbf{7}$ - $\mathbf{1 0}$ em diferentes conversões e seletividades.

$\mathrm{Na}$ figura 15 têm-se os cromatogramas das reações de redução da $o$ cloroacetofenona 8 obtidos com os fungos SMA2-8 e SGPY-41 isolados da alga marinha Sargassum sp.

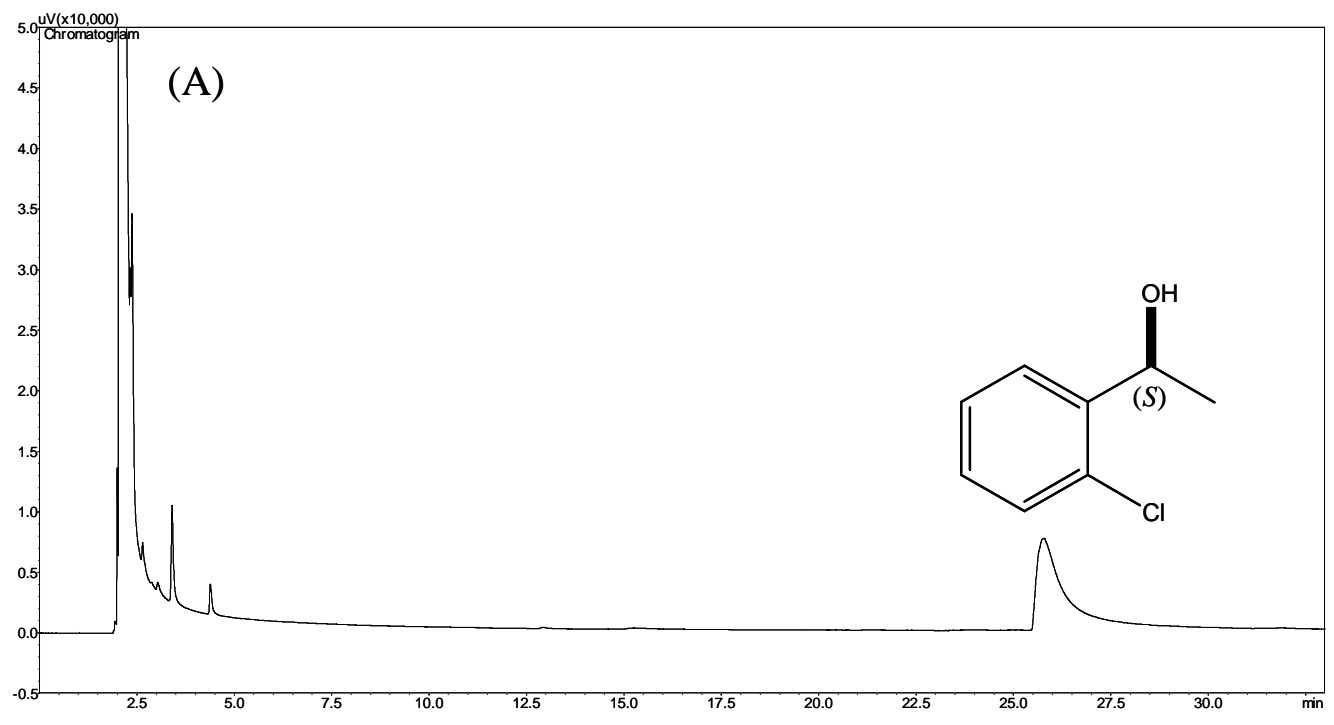




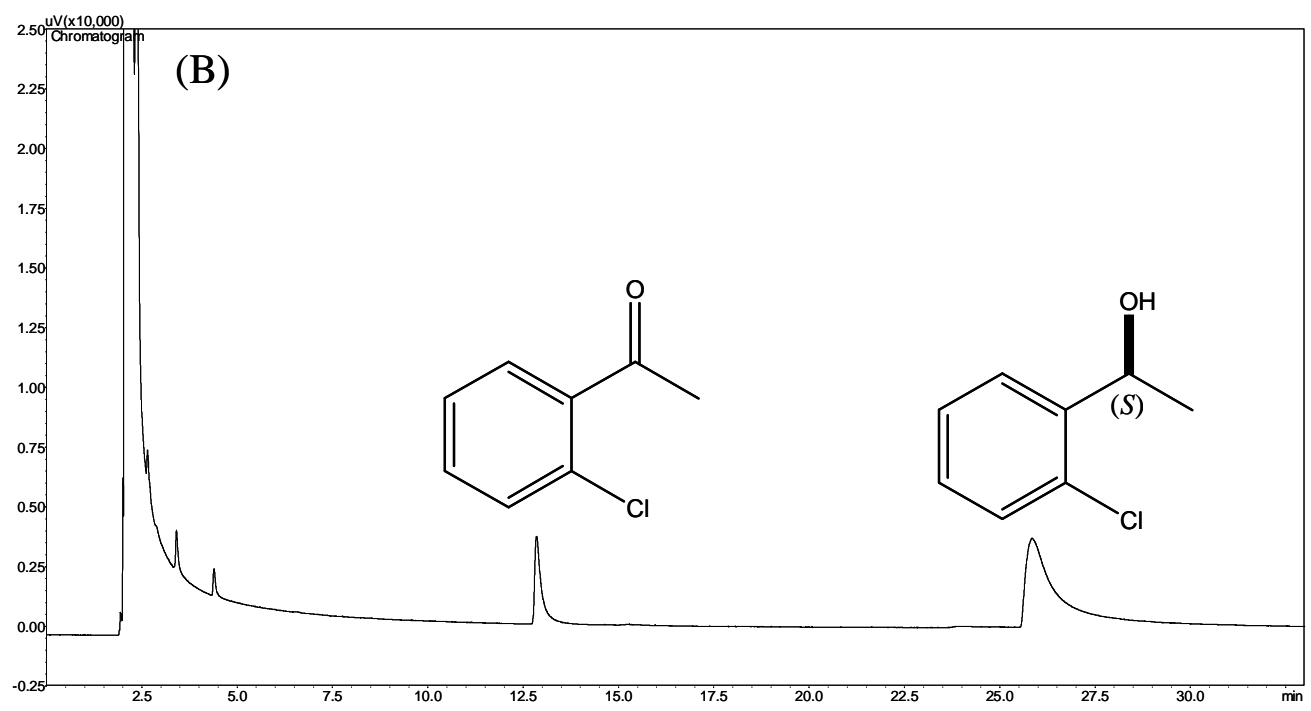

Figuras 15. Cromatogramas obtidos por CG das reações da $o$-cloroacetofenona $\mathbf{8}$ com fungos isolados da alga Sargassum sp com 10 dias de reação (A) fungo SMA2-8 (B) fungo SGPY-41.

\section{REDUÇÃO DE $\alpha$-TRIFLUORMETILCETONAS COM FUNGOS MARINHOS}

Nesta parte do trabalho realizou-se a redução de cetonas 1,3-dicarboniladas $\mathbf{1 5}$ - 16 com fungos marinhos. Os fungos foram isolados das esponjas marinhas Chelonaplysilla erecta e Geodia corticostylifera. As espécies utilizadas foram o Aspergillus sydowii Ce15, Aspergillus sydowii Ce19, Aspergillus sydowii Gc12, Bionectria sp Ce5, Penicillium raistrickii Ce16, Penicillium miczynskii Gc5 e o Trichoderma sp Gc1.

$\mathrm{Na}$ figura 16 têm-se as fotos de alguns fungos marinhos cultivados no laboratório e utilizados neste trabalho. 


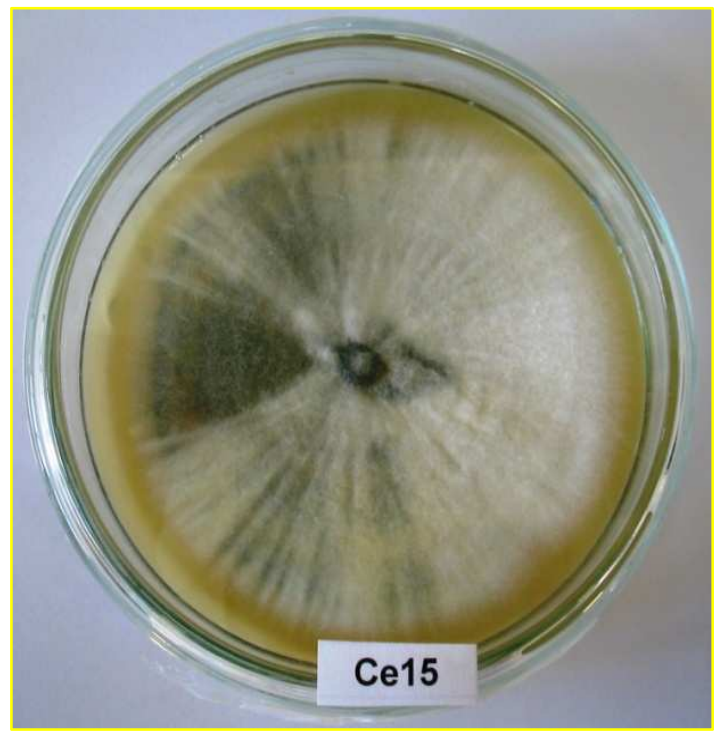

Aspergillus sydowii Ce15

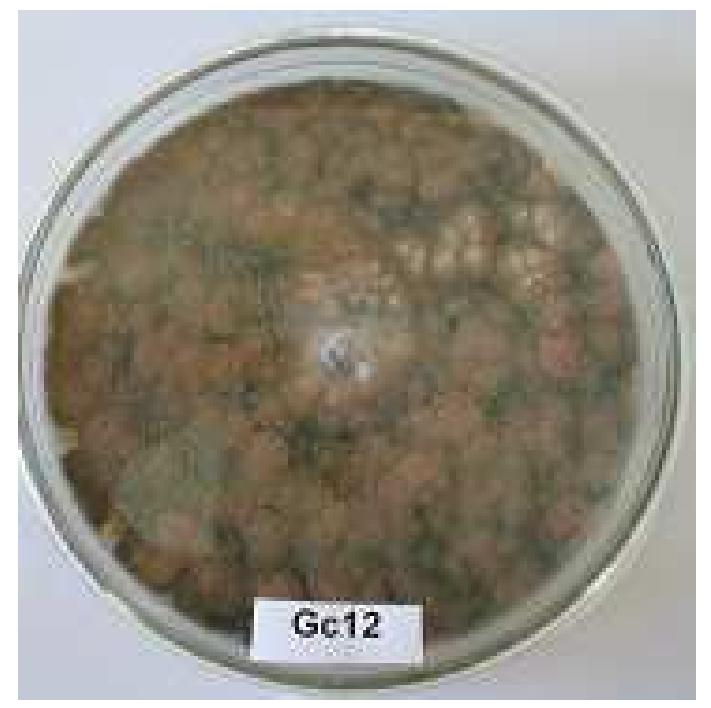

Aspergillus sydowii Gc12

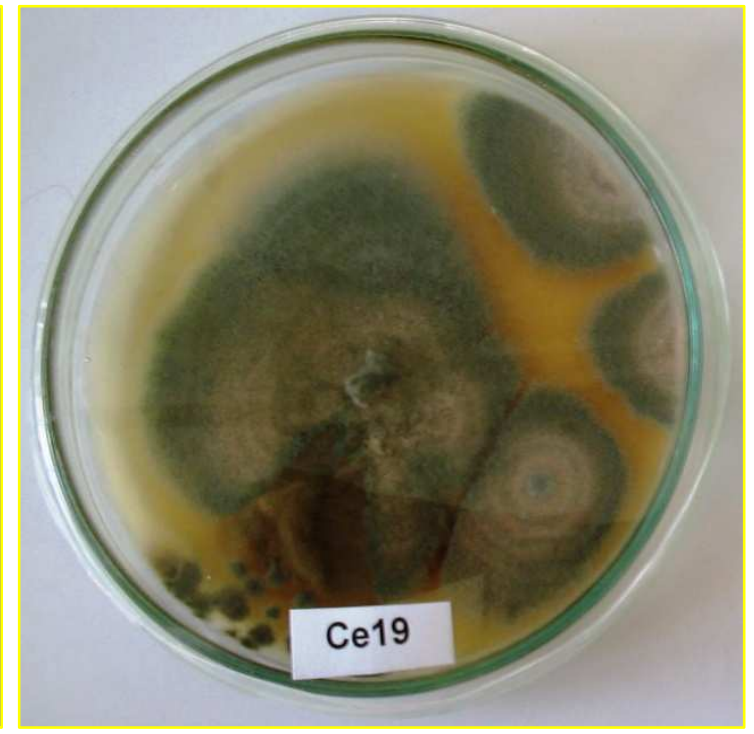

Aspergillus sydowii Ce19

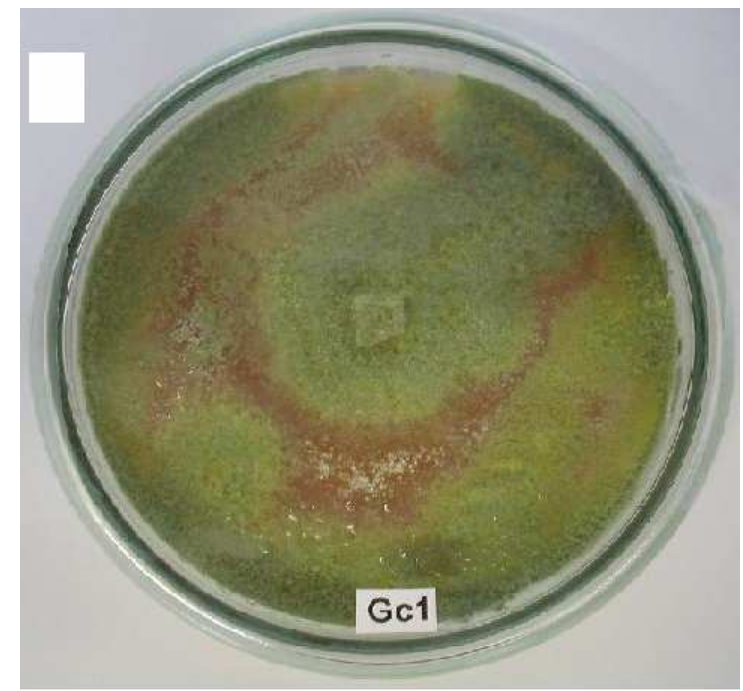

Trichoderma sp Gc1

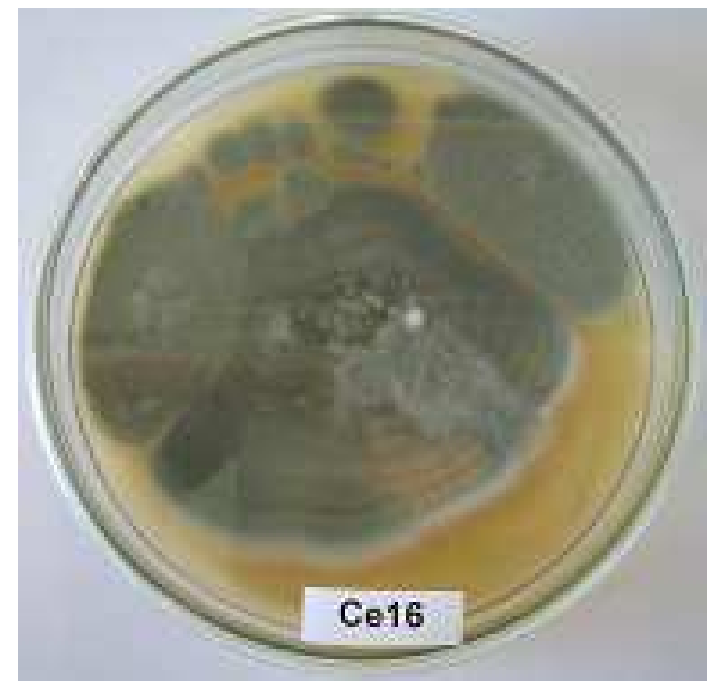

Penicillium raistrickii $\mathrm{Ce} 16$

Figura 16. Colônias de fungos marinhos cultivadas em extrato de malte $2 \%$ 
Os fungos foram cultivados por 5 dias em frascos erlenmeyer de $250 \mathrm{~mL}$, contendo $100 \mathrm{~mL}$ de extrato de malte $2 \%$ preparado em água do mar artificial. Após este período adicionou-se $50 \mathrm{mg}$ das cetonas $\mathbf{1 5}$ - 16 dissolvidas em $300 \mu \mathrm{L}$ de dimetilsulfóxido. As reações foram mantidas em agitação orbital. Alíquotas foram retiradas em tempos fixados e analisadas por cromatografia gasosa acoplada por cromatografia gasosa quiral. Os dados das reações de redução estão sumarizados nas tabelas 10 e 11.

Tabela 10. Redução da $\alpha$-trifluormetilcetona $\mathbf{1 5}$ com os fungos marinhos

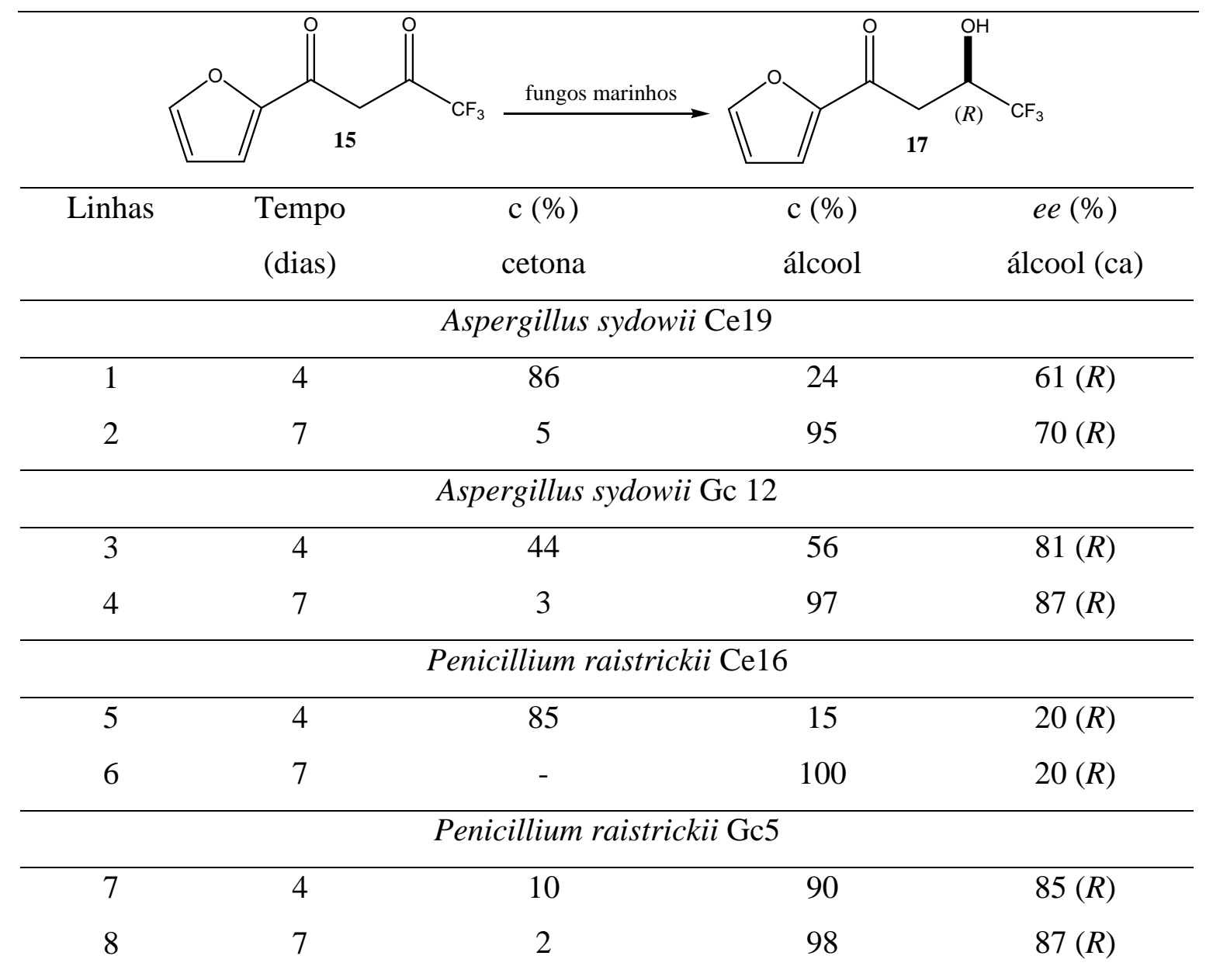

Condições reacionais: em frascos erlenmeyers de $250 \mathrm{~mL}$ foi adicionado o meio de cultura de extrato de malte $2 \%$ em água do mar artificial $(100 \mathrm{~mL})$. Cultivaram-se os fungos marinhos por 5 dias sob agitação orbital $\left(150 \mathrm{rpm}, 32{ }^{\circ} \mathrm{C}\right)$. Após este tempo adicionou-se ao meio de cultivo $50 \mathrm{mg}(0,24 \mathrm{mmol})$ da cetona 15 dissolvida em $300 \mu \mathrm{L}$ de DMSO. As reações foram mantidas sob agitação orbital $\left(150 \mathrm{rpm}, 32{ }^{\circ} \mathrm{C}\right)$. Alíquotas foram retiradas em tempos fixados e analisadas por cromatografia gasosa utilizando-se coluna quiral de ciclodextrina. c (\%): concentração determinada por CG; ee (\%): excesso enantiomérico; ca: configuração absoluta. 
Como observado na tabela 10 todos os fungos marinhos reduziram a cetona $\mathbf{1 5}$ no correspondente álcool $(R)$-17. Os fungos marinhos Aspergillus sydowii Gc $12 \mathrm{e}$ Penicillium raistrickii Gc5 isolados da esponja Geodia corticostylifera foram os que reduziram melhor o grupo $\alpha$-trifluormetilcarbonílico da cetona 15 fornecendo altas conversões e bons valores de excessos enantioméricos para o álcool $(R)$-17 (Linhas $4 \mathrm{e}$ 8, Tabela 10). Enquanto os fungos Aspergillus sydowii Ce19 e Penicillium raistrickii Ce16 isolados da esponja Chelonaplysilla erecta apresentaram menores seletividades para o álcool $(R)$-17 com 7 dias de reação (Linhas 2 - 6, Tabela 10).

As reduções catalisadas pelas enzimas dos fungos apresentaram regiosseletividade e estereosseletividade, pois ocorreu somente a redução do grupo $\alpha$ trifluorocarbonílico de $\mathbf{1 5}$ e com a formação preferencial do $S$-enantiômero do álcool 17. A configuração absoluta do álcool $(R)-\mathbf{1 7}$ foi determinada por comparação com a rotação descrita na literatura (Parte II, Materiais e Métodos). Neste caso, as enzimas dos fungos marinhos promoveram o ataque pela face si da cetona 17 , formando o álcool com configuração $(R)$, de acordo com a regra de Prelog (Figura 17).

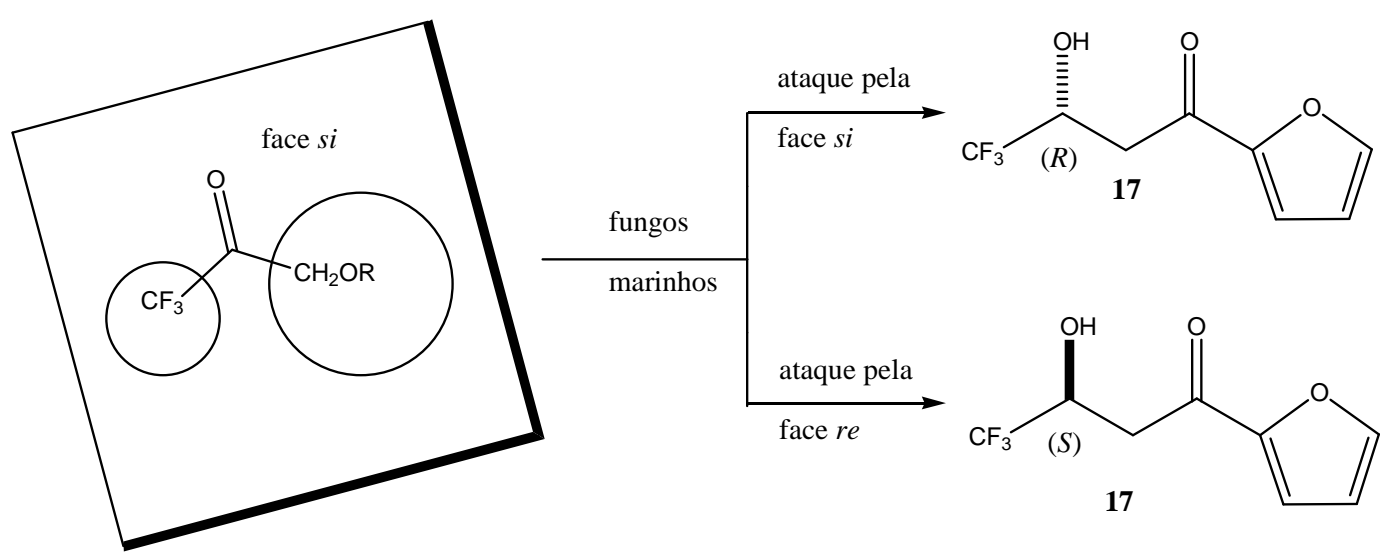

Figura 17. Regra de Prelog para a redução da cetona 17 com fungos marinhos 
As reações de redução da cetona $\mathbf{1 6}$ foram realizadas com os fungos marinhos Bionectria sp Ce5, Penicillium raistrickii Gc5 e Trichoderma sp Gc1 (Tabela 11). Todos os fungos reduziram o grupo $\alpha$-trifluormetilcarbonílico com boa seletividade, sendo que os melhores resultados foram com os fungos Penicillium raistrickii Gc5 e Trichoderma sp Gc1 (Linhas 4 e 6, Tabela 11). O fungo Bionectria sp Ce5 foi o que apresentou menor conversão (Linha 2, Tabela 11).

As reduções promovidas pelas enzimas destes fungos também foram regio- e estereosseletivas, pois ocorreu somente a redução do grupo $\alpha$-trifluorocarbonílico de $\mathbf{1 6}$ obtendo preferencialmente um enantiômero do álcool 17. Até o presente momento não foi determinada a configuração absoluta do álcool 17.

Tabela 11. Redução da $\alpha$-trifluormetilcetona $\mathbf{1 6}$ com os fungos marinhos

\begin{tabular}{lccc}
\hline & \\
\hline
\end{tabular}


ciclodextrina.c (\%): concentração determinada por CG; ee (\%): excesso enantiomérico; ca: configuração absoluta não determinada.

Na figura 18 têm-se os cromatogramas da dicetona 15 e do álcool racêmico 17 obtidos por cromatografia gasosa em coluna capilar de ciclodextrina.

Na figura 19 têm-se os cromatogramas das reações de redução da dicetona 15 obtidos com os fungos marinhos Penicillium raistrickii Gc5 e Aspergillus sydowii Ce19.

Na figura 20 têm-se os cromatogramas da dicetona 16 e do álcool racêmico 18 obtidos por cromatografia gasosa em coluna capilar de ciclodextrina.

Na figura 21 têm-se os cromatogramas das reações de redução da dicetona 16 obtidos com os fungos marinhos Penicillium raistrickii Gc5 e Bionectria sp Ce5.

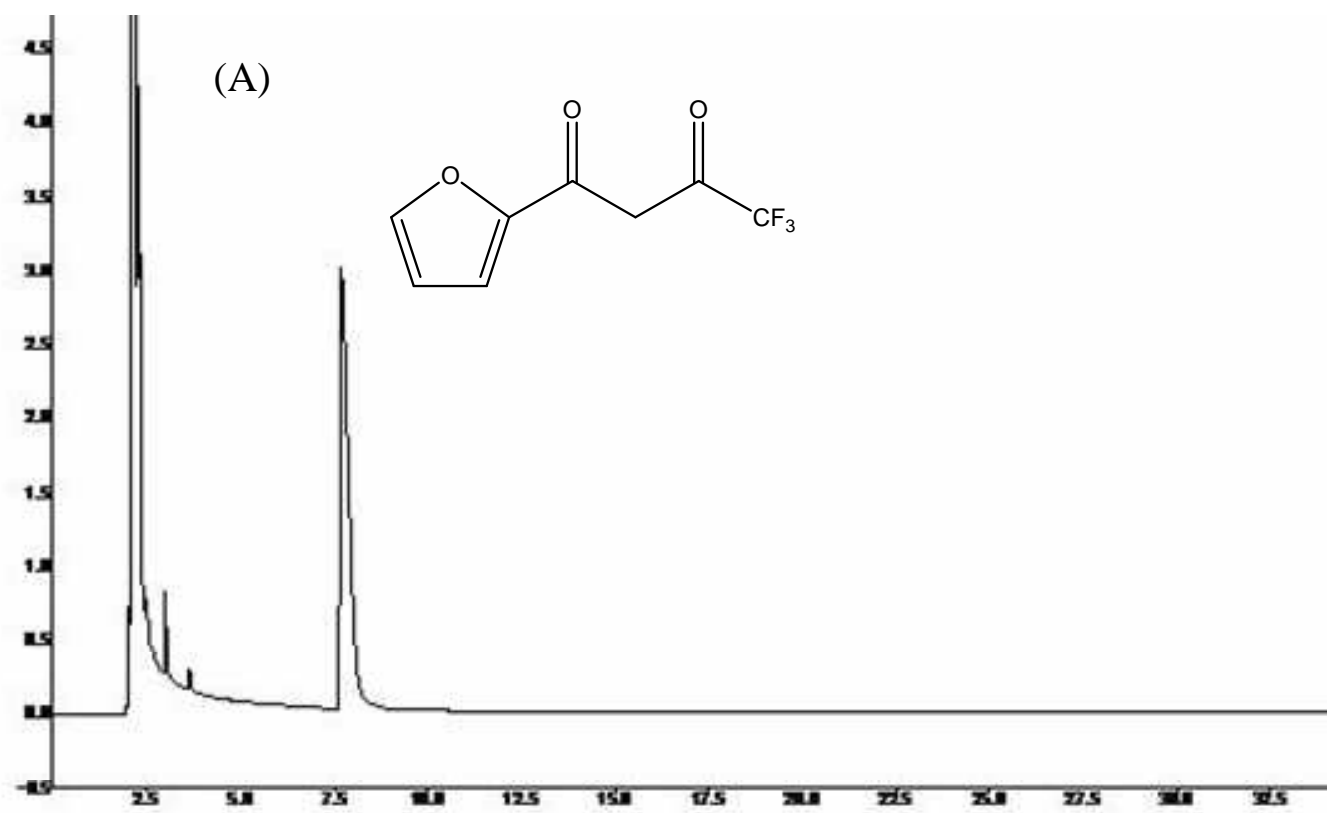




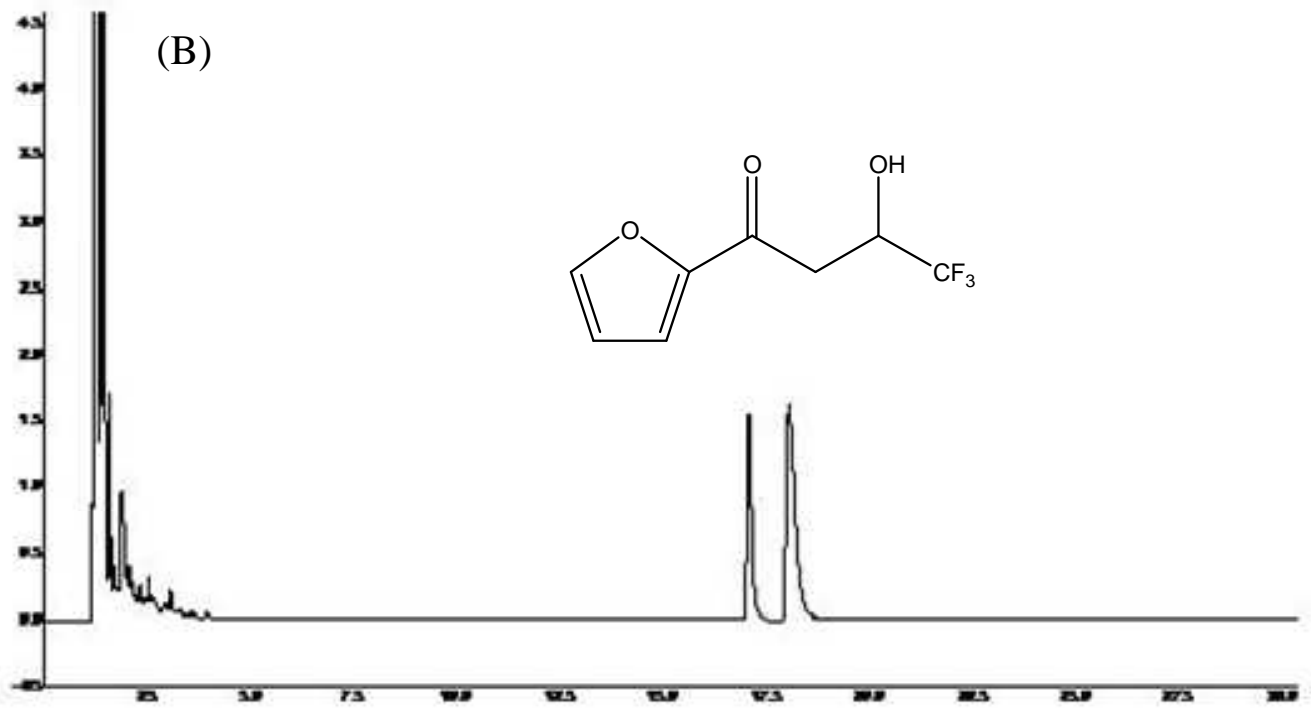

Figura 18. Cromatogramas obtidos por CG. (A) padrão da dicetona 15 (B) padrão do álcool rac-17

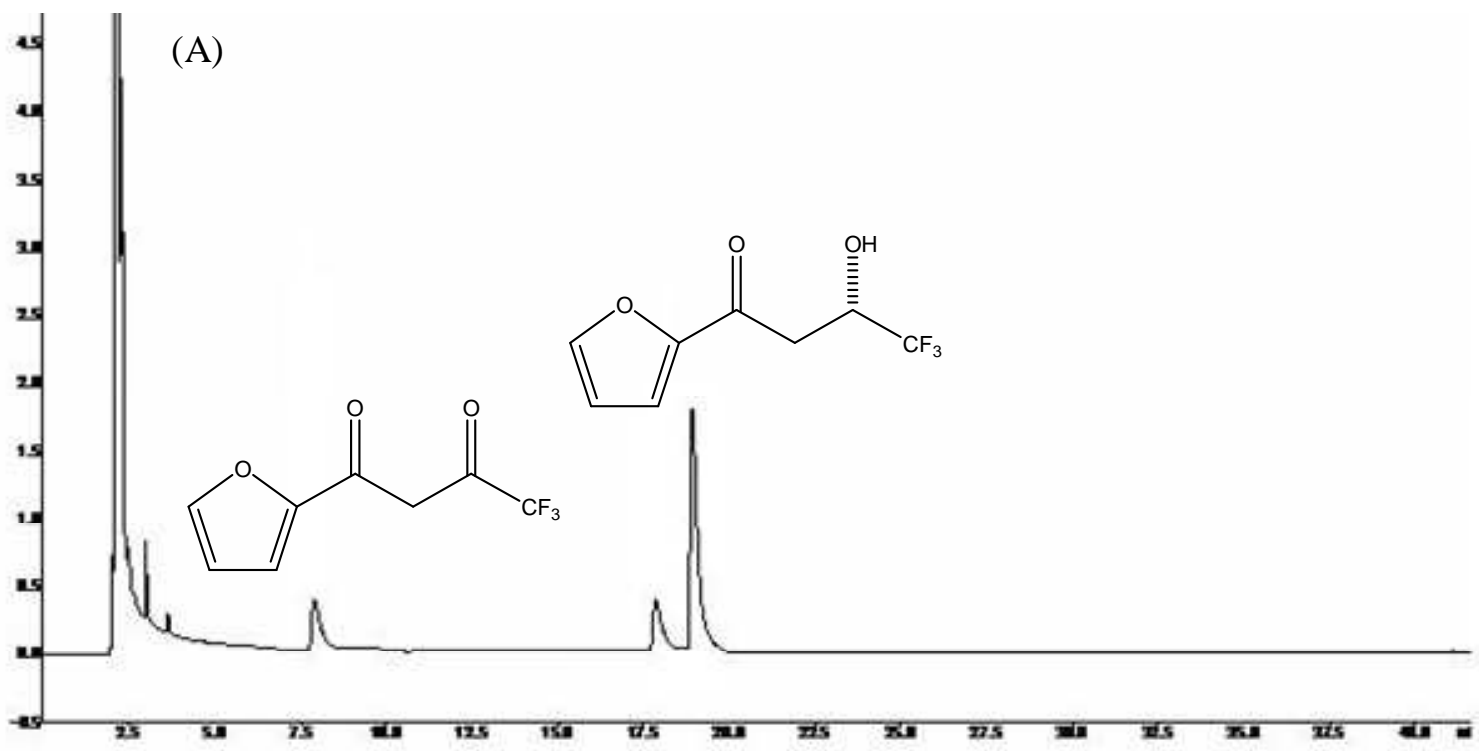




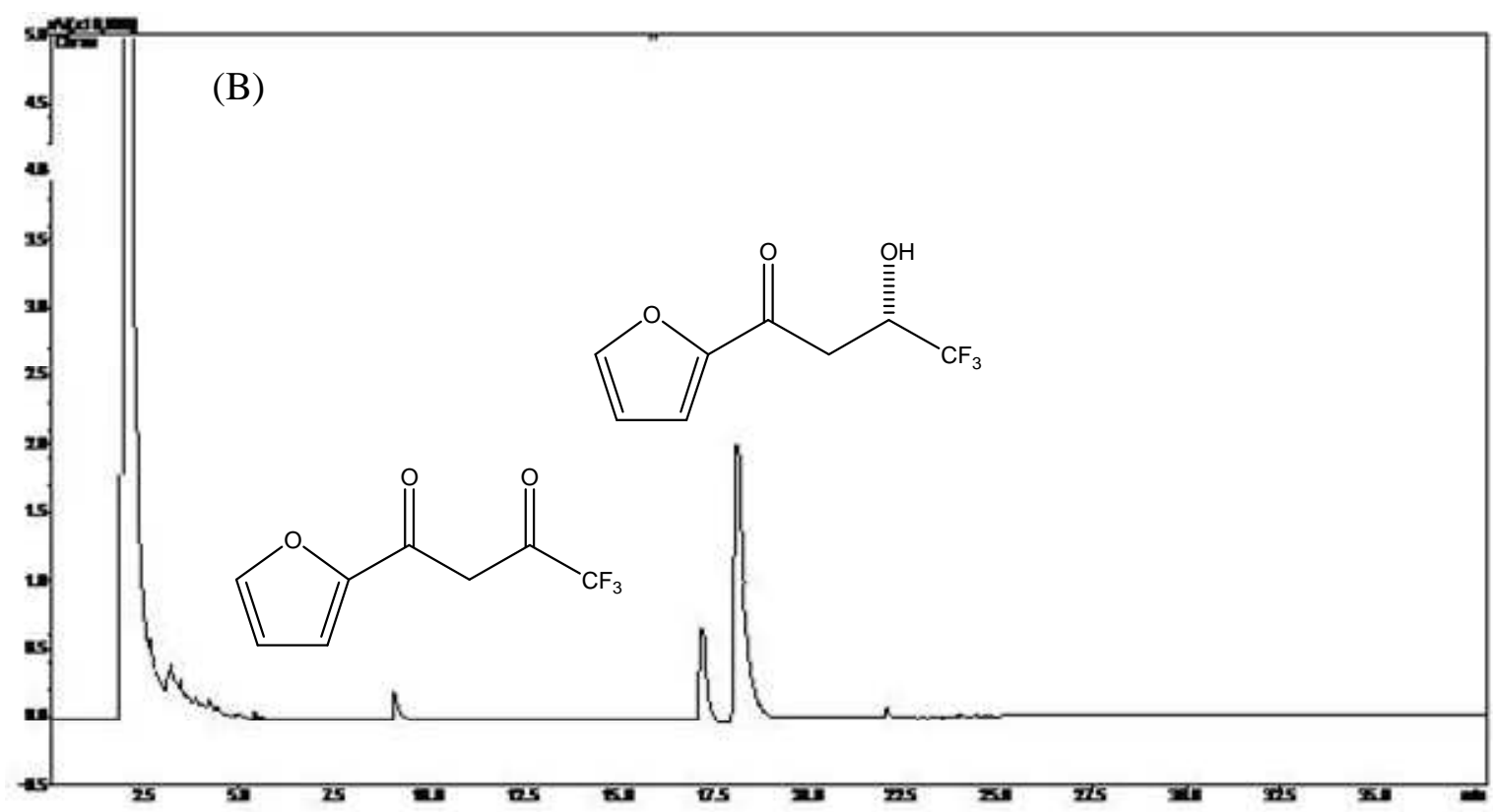

Figura 19. Cromatogramas obtidos por $\mathrm{CG}$ das reações da dicetona $\mathbf{1 5}$ com fungos marinhos com 7 dias de reação (A) Penicillium raistrickii Gc5 (B) Aspergillus sydowii Ce19

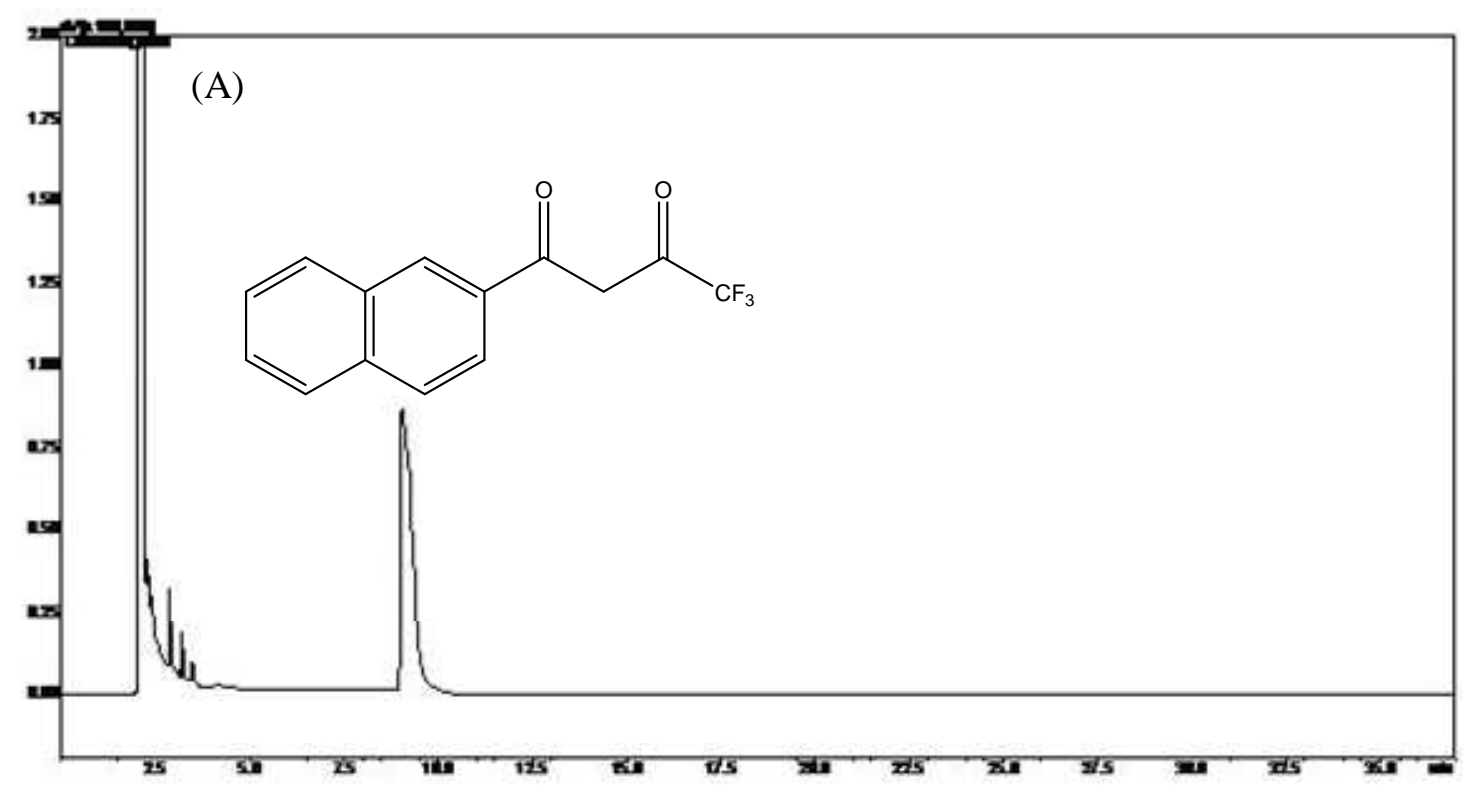




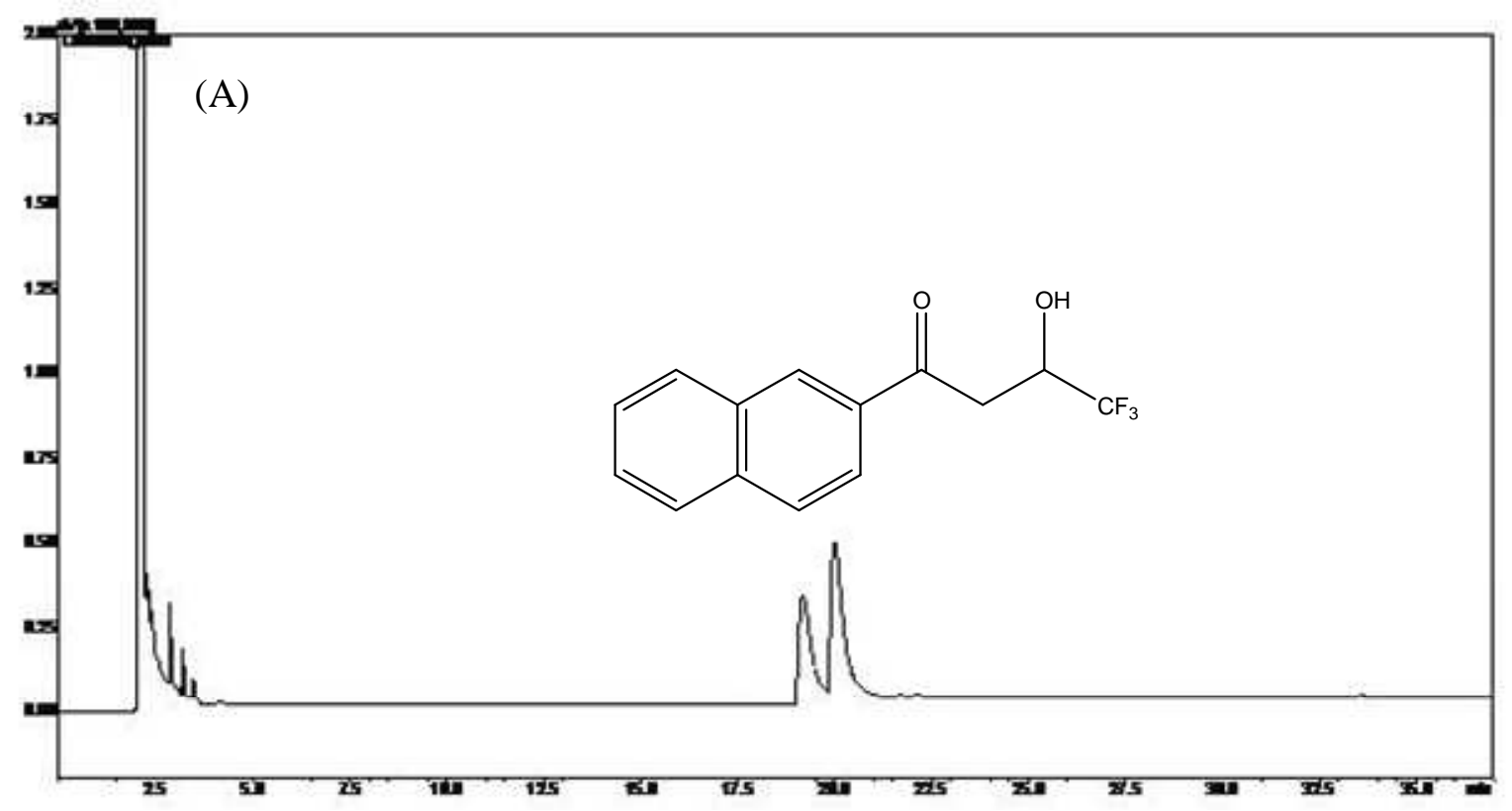

Figura 20. Cromatogramas obtidos por CG. (A) padrão da dicetona 16

(B) padrão do álcool $r a c-18$

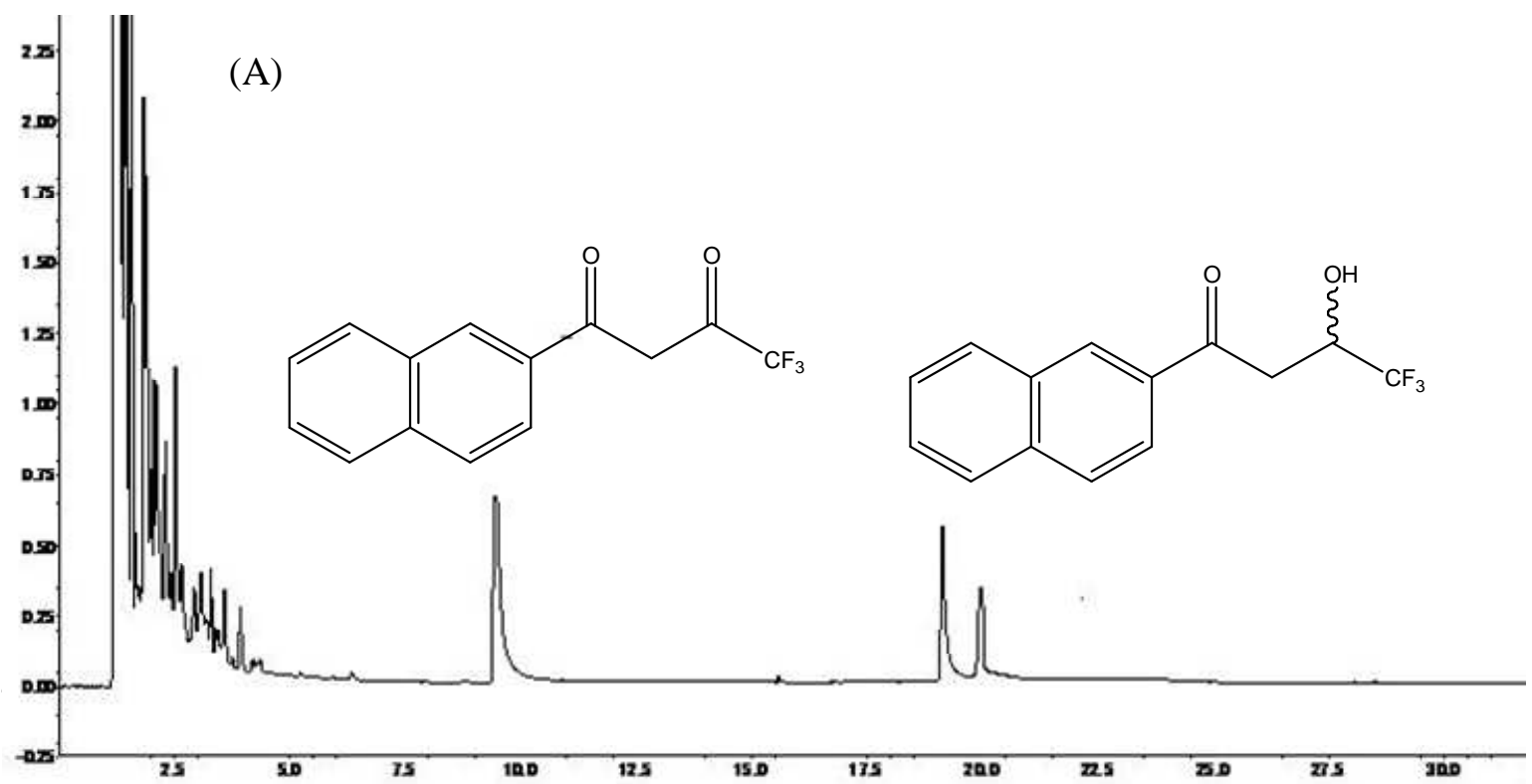

Figura 21. Cromatogramas obtidos por $\mathrm{CG}$ das reações da dicetona $\mathbf{1 5}$ com fungos marinhos em 7 dias de reação (A) Penicillium raistrickii Gc5 
As cetonas dicarboniladas 15 - 16 também foram submetidas às reações biocatalíticas com as algas Bostrychia tenella e Bostrychia radicans. Os resultados das reações estão sumarizados nas tabelas 12 e 13.

Em todos os casos as algas $B$. tenella e B. radicans catalisaram as reações de redução das cetonas $\mathbf{1 5}$ - $\mathbf{1 6}$ com altas seletividades, porém com baixas conversões (Tabelas 12 - 13). Os baixos valores de conversões podem ser em função da baixas quantidades enzimas presentes nas algas.

Tabela 12. Redução da $\alpha$-trifluormetilcetona 15 com as algas marinhas

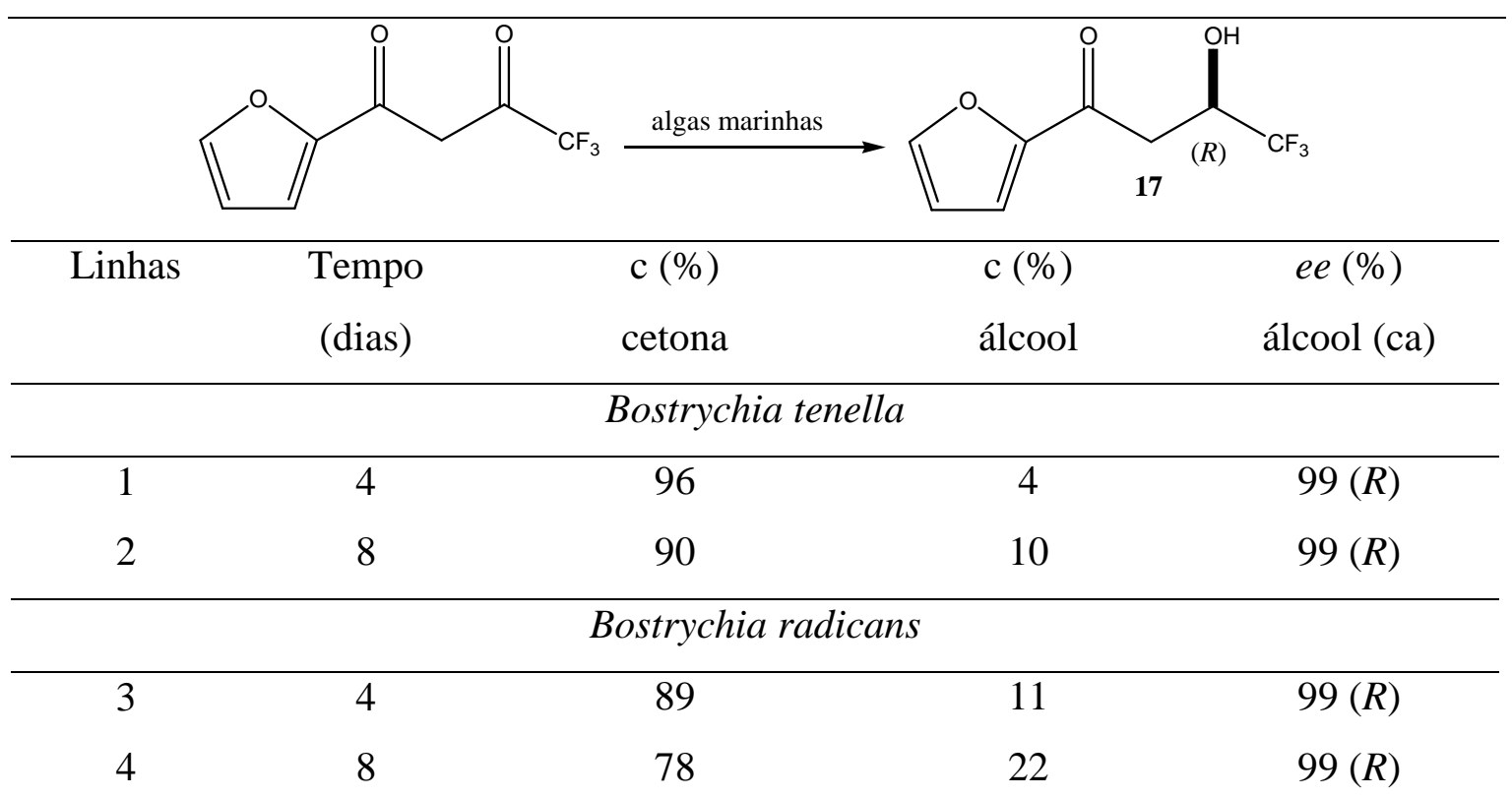

Condições reacionais: em frascos erlenmeyers de $250 \mathrm{~mL}$ foi adicionada água esterilizada (100 $\mathrm{mL})$, alga B. tenella ou B. radicans (5 g), $\alpha$-trifluormetilcetona 15 dissolvida em $300 \mu \mathrm{L}$ de DMSO. As reações foram mantidas sob agitação orbital $\left(150 \mathrm{rpm}, 32^{\circ} \mathrm{C}\right)$. Alíquotas foram retiradas em tempos fixados e analisadas por cromatografia gasosa utilizando-se coluna quiral de ciclodextrina. c (\%): concentração determinada por CG; ee (\%): excesso enantiomérico; ca: configuração absoluta. 
Tabela 13. Redução da $\alpha$-trifluormetilcetona $\mathbf{1 6}$ com as algas marinhas

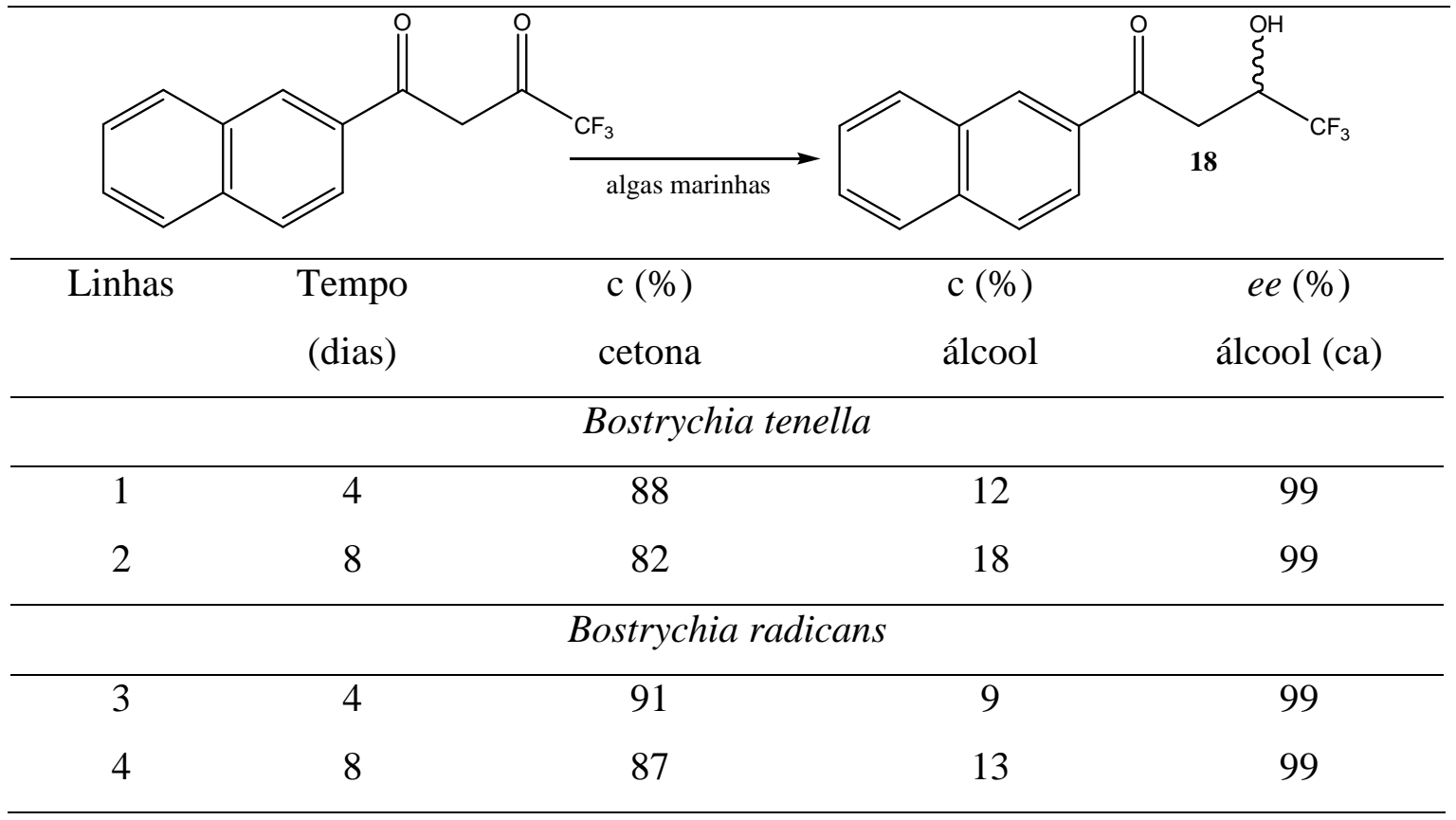

Condições reacionais: em frascos erlenmeyers de $250 \mathrm{~mL}$ foi adicionada água esterilizada (100 mL), alga B. tenella ou B. radicans (5 g), $\alpha$-trifluormetilcetona 16 dissolvida em $300 \mu \mathrm{L}$ de DMSO. As reações foram mantidas sob agitação orbital $\left(150 \mathrm{rpm}, 32{ }^{\circ} \mathrm{C}\right)$. Alíquotas foram retiradas em tempos fixados e analisadas por cromatografia gasosa utilizando-se coluna quiral de ciclodextrina. c (\%): concentração determinada por CG; $e e$ (\%): excesso enantiomérico; ca: configuração absoluta não determinada. 


\section{CONSIDERAÇÕES FINAIS}

O objetivo deste trabalho foi realizar reações de redução de cetonas proquirais com novos biocatalisadores. Apesar da grande extensão da costa marítima no país, o potencial biocatalítico de organismos marinhos (fungos, bactérias, algas) é pouco explorado. Neste sentido, o estudo realizado tem importância no que se refere ao emprego de algas e microrganismos marinhos como biocatalisadores, tornando-se um trabalho pioneiro.

Os resultados obtidos podem ser comparados com estudos realizados na literatura. Por exemplo, cinco espécies de algas marinhas foram estudadas em reações com derivados de acetofenonas. As algas Chlorella minutissima, Nannochloris atomus, Porphyridium purpureum, Dunaliella parva e Isochrysis galbana catalisaram a redução de cetonas com diferentes conversões e seletividades. A acetofenona foi reduzida no feniletanol após 5 dias de incubação com conversões de $65 \%$ e com excesso enantiomérico de $15 \%$ com a alga $C$. minutissima (Hook et al., 2003). Enquanto que a $p$-metilacetofenona e a $p$-hidroxiacetofenona nem sequer foram reduzidas pela alga $C$. minutissima (Hook et al., 2003). Estes resultados, de certa forma, são similares aos obtidos com as algas $B$. tenella e $B$. radicans, uma vez que de acordo com a estrutura dos substratos variou-se a seletividade e as conversões das reações. 


\section{CONCLUSÕES}

Neste trabalho foram realizadas reações de redução de cetonas utilizando diferentes organismos marinhos como biocatalisadores (algas, fungos e bactérias). Foram utilizados como substratos sete derivados de acetofenonas (1 -3 e $\mathbf{7}-\mathbf{1 0})$ e duas cetonas 1,3-dicarboniladas $(\mathbf{1 5}-\mathbf{1 6})$.

As algas $B$. tenella e $B$. radicans foram utilizados nas reações de redução das cetonas (1 -3, 7 - 10 e 15 - 16) e levaram a formação dos correspondentes alcoóis com excelentes seletividades, contudo observaram-se modestas conversões.

Também foram isoladas no laboratório as bactérias Bt-01 e Bt-02 das algas $B$. tenella e $B$. radicans, respectivamente. Estas bactérias promoveram as reduções de derivados de acetofenonas (1 -3 e 7 - 10), cujos resultados foram similares aos obtidos com as algas, ou seja, altos excessos enantioméricos e baixas conversões.

Ainda, realizaram-se as reações de redução das cetonas (1 -3 e $\mathbf{7}$ - 10) utilizando-se quatro linhagens de fungos isolados da alga Sargassum sp. Os fungos (SMA2-C, SMA2-8, SMA2-58, SGPY-41) catalisaram as reações de redução das cetonas aos respectivos alcoóis com diferentes conversões e seletividades.

Realizaram-se as reduções de duas cetonas dicarboniladas com sete linhagens de fungos marinhos (Aspergillus sydowii Ce15, Aspergillus sydowii Ce19, Aspergillus sydowii Gc12, Bionectria sp Ce5, Penicillium raistrickii Ce16, Penicillium miczynskii Gc5 e o Trichoderma sp Gc1). Todos os micro-organismos promoveram a redução regiosseletiva e estereosseletiva das cetonas dicarboniladas. Observou-se que o grupo $\alpha$ trifluorocarbonílico foi reduzido preferencialmente, em boas conversões e seletividades.

Ainda, as algas marinhas Bostrychia radicans e Bostrychia tenella demonstraram bom potencial biocatalisador para a obtenção de $(S)$-alcoóis em reações 
com derivados de acetofenonas. Através dos resultados obtidos, concluiu-se que as algas e seus micro-organismos associados têm potencial para serem utilizados como biocatalisadores em reações de redução. Portanto, estes organismos podem ser fontes de novas enzimas para processos biotecnológicos. Este trabalho foi o primeiro estudo realizado no país envolvendo algas marinhas e seus microrganismos associados. 
BIOCATALISADORES DE ORIGEM MARINHA (ALGAS,

BACTÉRIAS E FUNGOS) PARA REDUÇÃO ESTEREOSSELETIVA

DE CETONAS

REFERÊNCIAS BIBLIOGRÁFICAS 


\section{Referências Bibliográficas}

BONATO, S.P.; JABOR, V. A. P. Análise enantiosseletiva de fármacos: Contribuições da cromatografia líquida de alta eficiência e eletroforese capilar. Química Nova, v.28, p.683-689, 2005.

COOPER, E. L. Commentary on traditional and modern biomedical prospecting: Part II. Ecam, v.1, n. 2, p. 207-209, 2004.

DA ROCHA, L.C. Redução de derivados de acetofenonas com fungos de origem marinha. Dissertação(Mestrado)-Instituto de Química de São Carlos, Univerisidade de São Paulo, 2008.

DE CONTI, R.; RODRIGUEZ, J. A.; MORAN, J.S. Biocatálise: avanços recentes. Química Nova, v.24, p.672-676, 2001.

DRAUZ, K.; WALDMANN, H. Developments and trends in enzyme catalysis in nonconventional media. Biotechnology Advances. v. 20, p. 239-267, 2002.

FABER, K. Biotransformations in organic chemistry. 5.ed. Berlin: Springer-Verlag, 2004.

GUTMANN, O.; SCHWERDTFEGER, R.; RIEKS, A.; ANTRANIKIAN, G; KASHE, V.; BRUNNER.G. Enzyme catalysed reactions, enantiosselectivity and stability under high hidrostatic pressure. Process Technology Proceedings. v.12, p. 127-131, 1996.

HATANAKA, Y.; KOBAYASHI, O.; HIGASHIHARA, M.; HIYAMA, K. Reduction of hydroxiacetone with NADPH regenerated through photosynthetic pathway of the halotolerant alga. Journal of fermentation and Bioengenering. V.81, p. 378-385, 1996.

HOOK, I.I.; RYAN, S.; SHERIDAN, H. Biotransformations of aliphatic and aromatic ketones, including several monoterpenois ketones and their derivatives by five species of marine microalgae. Photochemistry, v. 63, p. 31-39, 2003.

ITOH, K.; SAKAMURI, H.; NAKAMURA, K.; HORIUCHI, C.A. Biocatalytic assymetric reduction of 3-acetilisoxazoles. Tetrahedron: Asymmetric, v. 6, p. 14031410, 2005. 
LEHNINGER, P.; DAVID, L.N.; MICHAEL, M.C. Principles of biochemistry. 4. ed. New York, Worth Publishers, 2000. p. 123

LILJEBLAD, A.; KANERVA, L.T. Biocatalysis as a profound tool in the preparation of highly enantiopure amino acids. Tetrahedron: Asymmetry, v.62, p.711-715, 2006.

LIKA, K.; PAPADAKIS, I.A. Modeling the biodegradation of phenolic compounds by microalgae. Journal of sea research, v.62, p. 135-146, 2009.

MARGOLIN, A. L. Enzymes in the synthesis of chiral drugs. Microbiology Technology, v. 15, p. 266- 280, 1993.

MATSUDA, T.; YAMANAKA, R.; NAKAMURA, K.; Recent progress in biocatalysis for asymmetric oxidation and reduction. Tetrahedron: Assymetry, v. 20, p. 513-557, 2009.

MOLINARI, F; ROMANO, D; GANDOLFI, R; GUALANDRIS, R.;FERRARA, N. Biocatalysis for use in pharmaceutical manufacturing. Journal of Biotechnology, v.131, p.98-121, 2007.

MUSA, M. M.; ZIELGELMANN-FJELD, K. I.; VIEILLE, C.; ZEIKUS, G.; PHILLPS, R.S. Assymetric reduction and oxidation of aromatic ketones and alcohols using W110A secondary alcohol dehidrogenase from Thermoanaerobacter ethanolicus. Journal of Organic chemistry, v. 72, p. 30-34, 2007.

NAKAMURA, K,; YAMANAKA, R.; MATSUDA T.; HARADA T. Recent developments in assimmetric reduction of ketones with biocatalysts. Tetrahedron: Asymmetry, v. 14, p. 2659-2681, 2003.

NAKAMURA, K.; YAMANAKA, R.; MATSUDA T.; HARADA T. Recent developments in assimmetric reduction of ketones with biocatalysts. Tetrehedron: Asymmetry, v. 14, p. 2659-2681, 2003.

QUEZADA, M.A.; CARBALLEIRA, J.D.; SINISTERRA, J.V. Monaskus kaoling CBS 302.78 immobilized in polyurethane foam using iso- propanol as co-substrate: optimized immobilization conditions of a fungus as biocatalyst for the reduction of ketones. Bioresource Technology, v 100, p. 2018- 2025, 2009. 
SAID, S.; PIETRO, C.L.R. Enzimas como agentes biotecnológicos. Ribeirão Preto: Legis Summa, 2004. p. 2

SILVA, L.M., A química para o desenvolvimento sustentável. Revista Ciência do ambiente.v.3, p.50-53. 2007.

UTSUKIHARA, T.; MISUMI, O.; KATO, N; KUROIWA, T.; HORUCHI, C.A. Reduction of various ketones by red algae. Tetrahedron: Asymmetry, v.17, p. 1179$1281,2006$.

UTSUKIHARA, T.; OKADA, S.; KATO, N.; HORIUCHI, C.A. Biotransformation of $\alpha$-bromo and $\alpha$-dibromo alkanone to $\alpha$-hidroxiketone and $\alpha$-diketone by Spirulina platensis. Journal of Molecular Catalysis, v.45, p. 68-72, 2007.

VIDOTTI, E.C.; ROLLEMBERG, M.C. Algas: Da economia nos ambientes aquáticos à biorremediação e à química analítica. Química Nova, v. 27, p. 139-145, 2004.

XU, F. Application of oxido-reductases: recent progress. Industrial Biotechnology, v.1.p. 38-50, 2005. 